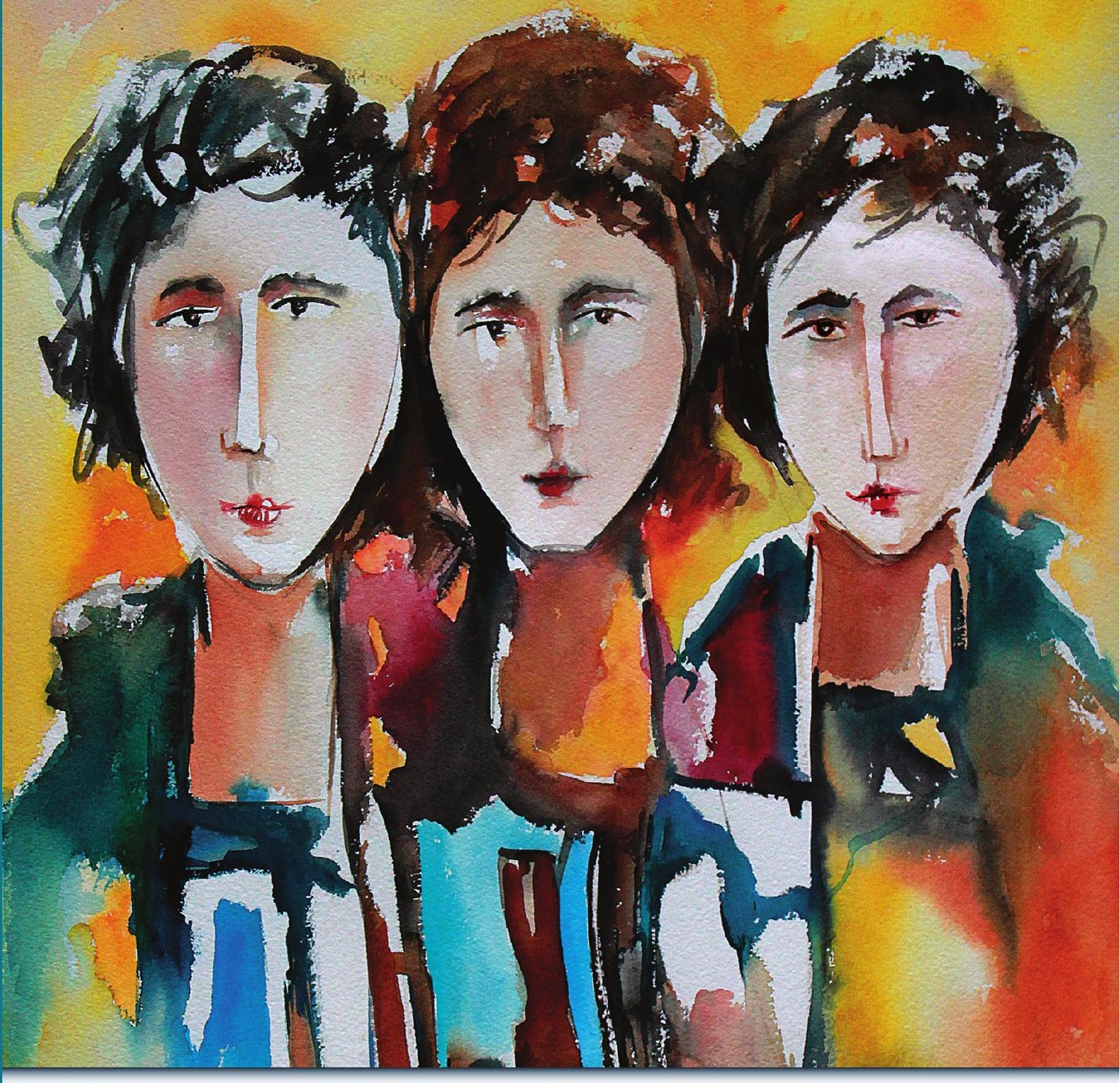

\title{
Identidades y lenguajes en la literatura escrita por mujeres
}

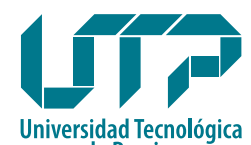
de Pereira

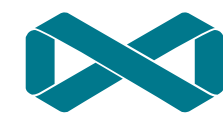

Editorial UTP
Susana Henao Montoya

Consuelo Chica

Olga Lucía Carmona Marín 
Susana Henao Montoya (Quimbaya, Quindío, Colombia, 1954)

Magíster en Literatura y Licenciada en Filosofía de la Universidad Tecnológica de Pereira. Profesora Titular del Departamento de Humanidades de la Facultad de Bellas Artes. Investiga en el campo de la literatura y sus publicaciones versan en este campo: Me subo al barco y viajo en él. Una experiencia de lenguaje en el mundo de los sordos. Pereira, Universidad Tecnológica, (2010), Procedimientos compulsivos. Calarcá: Editorial cuadernos negros, (2009), La ética Narrativa en la novela latinoamericana. La tejedora de coronas de Germán Espinosa y Gran sertón: veredas de Joao Guimarães Rosa (Ensayo 2009). Primer lugar Concurso Letras de Pereira para el mundo, (2010), Crónica satánica (Novela, 2004) Primer puesto en el Concurso Nacional de Novela Aniversario Ciudad de Pereira, 2004, Memorias de un niño que no creció. (Novela infantil, 2003) Finalista en el Concurso internacional de literatura infantil Julio C. Coba, Quito, 2003, Los hijos del agua (Novela). Bogotá, 1995, Primer puesto en el Concurso Nacional de Novela Aniversario Ciudad de Pereira, 1991. Primer lugar Concurso de novela del Gran Caldas, 1995, Crónicas de Temis. (Libro de cuentos, 1993) Primer lugar Concurso Autores pereiranos, 1993 Antesala del Paraíso y otros cuentos. (Libro de cuentos, 1993). Primer lugar Concurso escritores risaraldenses, 1993.

Pertenece al Grupo de Investigación Arte y Cultura 


\section{Identidades y lenguajes en la literatura escrita por mujeres}

Susana Henao Montoya

Consuelo Chica

Olga Lucía Carmona Marín

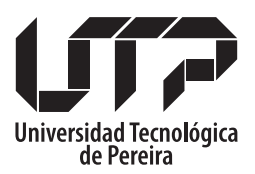

Facultad de Bellas Artes y Humanidades

Colección Trabajos de Investigación

2020 
Identidades y lenguajes en la literatura escrita por mujeres /

Susana Henao Montoya, Consuelo Chica y Olga Lucía

Carmona Marín. - Pereira : Universidad Tecnológica de

Pereira, 2020

157 páginas. - (Colección Trabajos de investigación).

elSBN: 978-958-722-492-4

1. Mujeres en la literatura 2. Pensamiento ético 3. Autoras latinoamericanas 4. Identidad femenina 5. Mujeres - Cultura

occidental 6. Mujeres - Desarrollo cultural 7. Sociolingüística

8. Sociocultura

CDD. 809.89287

Identidades y lenguajes en la literatura escrita por mujeres

(C) Susana Henao Montoya

(c) Consuelo Chica

(C) Olga Lucía Carmona Marín

(C) Universidad Tecnológica de Pereira

ISBN: 978-958-722-491-7

eISBN: 978-958-722-492-4

Imagen de cubierta: Jesús Calle, autor de la obra Retrato de familia, acuarela, 80x60 cm. 1989.

Proyecto de Investigación: Lenguajes e identidades

femeninas en la literatura escrita por mujeres, inscrito con el código 1-17-9

Universidad Tecnológica de Pereira

Vicerrectoría de Investigaciones, Innovación y Extensión

Editorial Universidad Tecnológica de Pereira

Pereira, Colombia

\section{Coordinador editorial:}

Luis Miguel Vargas Valencia

luismvargas@utp.edu.co

Teléfono 3137381

Edificio 9, Biblioteca Central "Jorge Roa Martínez"

Cra. 27 No. 10-02 Los Álamos, Pereira, Colombia

www.utp.edu.co

Montaje y producción:

María Alejandra Henao Jiménez

Universidad Tecnológica de Pereira

Pereira

Impresión y acabados:

Gráficas Olimpica

Pereira 


\section{Dedicatoria}

A la posibilidad de encuentro cuando el afecto se hace presente.

A la sororidad.

A las matronas venerables, a las dulces niñas extraviadas, a las hijas y a las madres, a las mujeres que luchan en la arena pública, a las amigas que ríen en sus huertos secretos. 



\section{Agradecimientos}

Queremos agradecer a nuestro grupo de investigación Arte y Cultura del Departamento de Humanidades de la Universidad Tecnológica de Pereira y a su directora, Margarita Calle, por el respaldo a nuestro trabajo. De la misma manera, a la Vicerrectoría de Investigaciones, Innovación y Extensión por el apoyo, el permanente acompañamiento, la orientación y la confianza depositada en los procesos investigativos. Igualmente, gracias para la escritora María Teresa Andruetto por acceder a una entrevista y ayudarnos a poner en claro algunas ideas. También para aquellas organizaciones culturales como Biblioteca Comfenalco de la ciudad de Armenia y Feria del Libro del Eje Cafetero en Pereira, por cedernos un espacio para socializar los avances y las conclusiones del proyecto. La conversación con el público hace que las ideas sean puestas a prueba, que se problematicen aspectos no considerados antes, que aparezcan opciones inéditas en la mente del investigador y se enriquezcan los puntos de vista. De ahí que esos espacios de confluencia mantengan vivo el compromiso del investigador con la comprensión de los problemas por parte de los colectivos involucrados con ellos. 



\section{CONTENIDO}

\section{CAPÍTULO 1.}

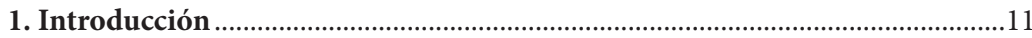

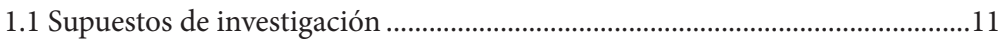

1.2 Identidades y lenguajes en la literatura escrita por mujeres..............................17

1.3 Una ética de la vulnerabilidad y la dependencia ..............................................24

$1.4 \mathrm{La}$ antiepicidad como rasgo ético de la literatura escrita por mujeres...........27

\section{CAPÍTULO 2.}

2. Procedimientos narrativos antiépicos....................................................................43

2.1 Una narración antiépica: un caso de no yo ......................................................43

2.2 La lógica "puesta en juego" en las prácticas discursivas femeninas ................55

2.3 Los mecanismos de la concienciación de los personajes femeninos ...............66

2.4 El silencio como marca en el lenguaje femenino...............................................84

2.5 La escritura como deconstrucción del orden patriarcal: La azotea de

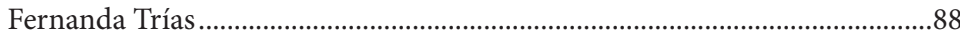

2.6 Lo político como elemento configurador de la identidad femenina...............95

2.7 La crónica como escritura femenina para tiempos difíciles........................... 106

CAPÍTULO 3.

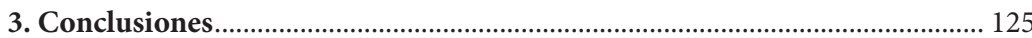

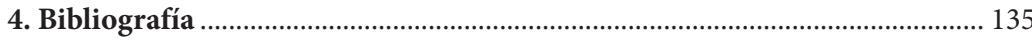

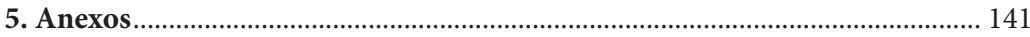

Anexo 1. Entrevista a María Teresa Andruetto..................................................... 141 



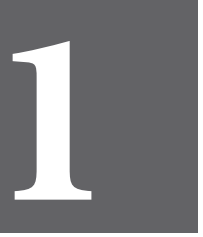

CAPÍTULO

UNO 



\section{Introducción}

\subsection{Supuestos de investigación}

El proyecto de investigación Lenguajes e identidadesfemeninas en la literatura escrita por mujeres, se propuso como la indagación de un corpus narrativo - novela, crónica, y autobiografía- escrita por autoras latinoamericanas en nuestra contemporaneidad con la intención de vincular sus temáticas, procedimientos narrativos, lenguajes, técnicas literarias y uso de los diversos recursos disponibles para el escritor, con los modos de vida, expectativas, roles y posiciones políticas que han correspondido históricamente a las mujeres en la cultura occidental. Así también, examinó diversos acercamientos críticos a la narrativa, presentados por escritoras y académicas interesadas en las problemáticas de las identidades femeninas. Este conjunto de textos creativos y críticos hace parte de las literaturas emergentes que van consolidando voces singulares, silenciadas o ignoradas, capaces de configurar una perspectiva potente para comprender muchos de los procesos socioculturales que se despliegan en nuestro presente.

El punto de partida fueron textos de algunas autoras latinoamericanas nacidas en el siglo XX, sobre los que esbozamos una mirada de género, aunque no intentamos sumarnos de manera 
importante a los debates sobre el feminismo, incorporamos a la investigación autoras -Ruby de María Gómez o Hélène Cixous inscritas en la corriente feminista de la diferencia en la que se reconocen las distinciones biológicas y culturales entre los dos sexos, se busca resignificar la experiencia femenina del mundo, así como pensar una humanidad por fuera del proyecto androcéntrico para desculturizar y renovar los discursos y los campos del saber tanto teóricos como prácticos. Al igual que a ellas, nos interesa tomar posición, no tanto para el debate político, el cual es difícil y cambiante, pero sí para para reivindicar la narración femenina como un modo de construir una experiencia del mundo con el fin de postularla como experiencia alternativa a las mediaciones y significaciones corrientes de nuestro universo simbólico. Una de las derivas del proyecto de la diferencia apunta a la construcción de un proyecto filosófico que ligue teoría y práctica en un orden simbólico marcado por la experiencia femenina, del cual resultaría la crítica a la cultura patriarcal, el reconocimiento de un mundo abierto a la diversidad y la incorporación de las potencias creadoras de la vida y la lengua como lengua madre. Estos pasos conducen al encuentro de significados diferentes acerca del yo, del otro y los fines de la vida y por tanto a la posibilidad de un proyecto distinto de humanidad. Es claro, que sin ser homogénea para todas las escritoras, la experiencia de mundo de las mujeres puede validarse como cuerpo escritural válido para el análisis, ya que responde a una subjetividad de dudoso reconocimiento, una existencia asentada sobre la dependencia -no la autonomía-; sobre el rol social -no la individualidad; y sobre la construcción de las nociones de cuerpo y sexualidad entendidos como respuesta al deseo ajeno -no la autorrealización- o el propio deseo-.

Llevar adelante una investigación sobre identidad femenina es algo comprometedor, por decir lo menos, ya que parece implicar adhesión a algunos de los planteamientos de los estudios de género. Sin embargo, inspiradas en las ideas de Heidegger, Ricoeur y las corrientes de la sociolingüística acerca del papel del lenguaje en el desarrollo de la cultura, nos mantuvimos en la convicción de 
que existe una relación entre identidad y discurso, tal como lo habíamos hecho en investigaciones anteriores sobre la lengua de señas y la identidad de los sordos, o sobre estructuras narrativas y pensamiento ético. De la anterior investigación, trajimos la idea de la racionalidad occidental como una condición capaz de crear un vínculo entre la epicidad de los relatos literarios y el esquema patriarcal de organización social a través de un potente sistema de dualidades asimétricas para nominar, clasificar y ordenar el mundo, tanto natural como social. De estas últimas hacen parte nuestras distinciones entre bien y mal; femenino y masculino; naturaleza y cultura; público y privado; razón y emoción.

La categoría epicidad, un concepto usado para referir el estado de cosas alrededor de la vigilia consciente de los caballeros antes de su nombramiento como tales, la comprendimos bajo un conjunto de características narrativas que incluye varias operaciones: el tratamiento lineal del tiempo, el uso de lenguaje proposicional que organiza de manera jerarquizada el relato de las experiencias, la necesidad de finales cerrados y la clausura de las anécdotas, el planteamiento de una trama agonística de lucha entre un protagonista y un antagonista y, finalmente, la alusión a un proyecto de vida que puede abrir o clausurar límites para la humanidad. La crítica literaria encuentra que las novelas femeninas frecuentemente carecen de estas propiedades, pues han estado excluidas de los roles externos al mundo doméstico, de los protagonismos de la Historia, de los problemas dela gobernabilidad o la legislación y de otros que atañen a la vida pública. Pero en la experiencia de estar presentes para otros, del cuidar de otros hasta el punto de negarse un proyecto de vida propio aparecen elementos que pueden crear un universo de categorías narrativas capaces de hacer visible las experiencias femeninas del mundo en sus roles biológicos, psicológicos y político-sociales.

Los relatos escritos por mujeres elegidos como corpus de la investigación, novelas, crónicas o narraciones biográficas fueron analizados a la luz de una categoría a la que, como consecuencia de 
la observación anterior, llamamos antiepicidad, pues muchos de ellos exhiben -en sus procedimientos narrativos, construcción de personajes y desarrollo de la trama- la deconstrucción de lo que ya mencionamos como característica del relato épico. Ya Bajtín había dicho a mediados del siglo pasado que las novelas en general son dialógicas y tienen la capacidad de crearficciones dondelas acciones del protagonista se oponen al statu quo y de hecho ellas han sido correlato de proyectos políticos emancipadores. Pero luego se han ido solidificando, un poco por un exceso de individualismo y a veces por un exceso de racionalidad. La antiepicidad vendría a ser el dispositivo técnico mediante el cual el dialogismo se expresa, así como se expresan particularidades sintácticas, planteamiento de personajes en relaciones sintagmáticas mejor que paradigmáticas, la subjetividad construida de frente al espejo de las generaciones antes que de manera autónoma y racional; los valores en relación con el afecto y el afecto como condición de la existencia.

Nuestro corpus se ha elegido en atención al lugar que ocupan las escritoras para la crítica literaria clásica o tradicional, pero atendiendo a nuestros propios ejercicios de lectura en los que pudimos ubicar los elementos que hicieron posible proponer la categoría de antiepicidad como la guía para el análisis. Es obvio que no puede afirmarse que estos elementos hallados durante el tiempo de la investigación sean los únicos rasgos propios de la literatura escrita por mujeres, pero la mayoría de ellos pueden explicarse desde una experiencia de mundo peculiar y nos permite proyectar una ética que incluye ideas sobre un yo con "naturales" rasgos femeninos. Una ética que revela un conjunto de criterios para la acción provenientes del sentimiento de exclusión social y cultural, de la condición biológica y el ejercicio de la maternidad que gobierna la vida de una gran parte de las mujeres, de la sensibilidad y de los hábitos de vida al cuidado de la familia y el hogar. En cuanto a lo literario, el lenguaje antiépico se sitúa en el no lugar: dudas, frases vacilantes, silencios, ambigüedades, repeticiones, inversiones, ironías, contradicción, el peso insustancial del signo indicial y sus consideraciones. De 
otra parte, buscamos que las autoras elegidas pertenecieran a distintas regiones latinoamericanas y en general lo hemos logrado. También hemos decidido incluir crónica y no sólo novela, con el fin de mirar si el trabajo de las mujeres escritoras contribuye a la formulación de un proyecto político a partir no sólo de las ficciones narrativas sino el testimonio directo o indirecto de los hechos sociales.

Por último, en la tarea de vincular los hallazgos literarios con un sentido particular en el plano de la existencia concreta, compartimos la idea de Rubí de María Gómez Campos acerca de que las mujeres tienen un proyecto de humanidad diferente del proyecto patriarcal. Una vez aceptada esa opción, encontramos que en sus obras, estas mujeres escritoras elegidas en el corpus "mujeres" proponen una alternativa a los relatos fabricados según una visión de mundo ordenada y homogenizada, organizada según leyes universales. Grandes relatos o narraciones paradigmáticas que en lo moral, requieren el cálculo racional, y en las narraciones, la supremacía personal, pues la vida parece el escenario de un combate entre la fortuna y el descalabro. Muy por el contrario el nuevo proyecto de humanidad subvierte los estereotipos, engrandece los afectos, entiende la finitud y la vulnerabilidad como aspectos constitutivos de lo humano y entiende la conciencia como confluencia de reflexiones intelectuales a la vez que experiencias vivenciales.

Somos conscientes de que una investigación como esta requiere extremo cuidado ya que las categorías de mujer, femenino y literatura femenina demandan mucha atención. Nosotras hemos puesto el énfasis en las relaciones entre antiepicidad y relato, ética e ideas de yo y de otro, vulnerabilidad, y por último, identidad y vida concreta. Como dijimos antes, no avanzamos hacia la problemática del género ni denunciamos las dificultades de las escritoras en el panorama literario patriarcal, así como tampoco nos adentramos en discusiones sobre la igualdad de los sexos. Nos interesamos en investigar un conjunto de significados presentes en los discursos 
femeninos y examinar su pertinencia para la construcción de un proyecto ético susceptible de enriquecer modelos éticos existentes en la cultura occidental. Las prácticas de la vida cotidiana, el mundo de la casa y de la vida, y en general, el ámbito de lo privado son un reservorio de significaciones y procedimientos lingüísticos usados en sus textos por mujeres. Aceptar que pueden salir de su lugar de enunciación para impregnar la literatura y de ahí las disciplinas desde las que se legisla lo social y lo político, significa que el proyecto ético pudiera llegar a alcanzar su cometido. Sin embargo, debemos ser cuidadosas al imaginar los alcances de un posible proyecto ético femenino por cuanto lo que parece estar incrementándose en este momento es el desconocimiento de las mujeres como seres humanos plenos y asistimos a una violencia mayor y más cruel sobre la humanidad femenina. Feminicidios y explotación sexual nos indican que las preguntas éticas fundamentales en cuanto a la identidad de la mujer tienen sin cuidado el accionar político patriarcal. Buena parte del discurso coloquial cotidiano y algunas de sus expresiones más populares como los géneros musicales urbanos apoya una representación de la feminidad en la que las mujeres siguen siendo animales, hasta el punto en que ellas están llamándose a sí mismas perras.

De todos modos, un estudio literario no puede pretender erigirse en aparato de conocimiento y reconocimiento cabal, pero puede servir como dispositivo de visibilización de prácticas, maneras de decir y comportarse de sujetos creativos a la hora de hacer emerger historias para comunicar sus experiencias. Autores como Bajtín, Bruner, Ricoeur, MacIntyre, Michel de Certeau, Martha Nussbaum, Biruté Ciplijauskaité, Hélène Cixous y Virginia Woolf fueron la fuente teórica para conducir la unidad del presente estudio.

El proyecto aparece inscrito en la línea de Estudios culturales y narrativas contemporáneas del grupo Arte y Cultura del Departamento de Humanidades - Facultad de Bellas Artes y Humanidades de la Universidad Tecnológica de Pereira. 
Metodológicamente se sitúa dentro de las corrientes de la hermenéutica que a la vez que teoría filosófica sobre la unidad entre pensamiento y lenguaje o entre ser y lenguaje, se instituye como método de comprensión e interpretación que presta especial atención a las estructuras narrativas, las tramas, los lenguajes, las figuras literarias, las propiedades textuales y las relaciones texto-contexto como formas discursivas que se entretejen con los comportamientos existenciales. Dentro de esta perspectiva metodológica los recursos narrativos se comprenden como expresión de una voluntad transformadora de la realidad que los personajes de las narraciones exhiben, tal como si fueran sujetos pertenecientes a grupos sociales presentes en nuestra realidad. El mundo se ofrece como un texto a ser descifrado a condición de que las narraciones puedan darle unidad en el despliegue de sus tramas. Como investigadoras perseguiremos en la narración la categoría de intención ya que la intención, según Ricoeur, es a la acción narrativa lo que la causalidad es al mundo de las entidades físicas. Otras categorías como la de epicidad, concienciación, situación, sí mismo, otro, temporalidad, fragmento y totalidad se vinculan a la anterior para asumir la interpretación del universo femenino a partir de sus narraciones.

\subsection{Identidades y lenguajes en la literatura escrita por mujeres}

Es difícil imaginar un campo disciplinar tan cambiante como el de los estudios de género, pero sólo dentro de él vale la pena adelantar una indagación que busque una configuración para la categoría de mujer o la categoría de literatura femenina. Adoptar la perspectiva de género en esta investigación implica situar el análisis literario en el ámbito de las relaciones de poder y el peso de los condicionamientos históricos sobre las obras y las autoras. También implica que las consideraciones socioculturales de nuestro contexto existencial se trasladan al universo de la ficción. En el presente trabajo intentamos formular una argumentación que nos lleve al establecimiento de nuestras conclusiones sin adhesiones directas a corrientes feministas, sobre todo, 
las corrientes de la igualdad, pues los planteamientos de sus militantes parecen cambiar los condicionamientos biológicos por los condicionamientos culturales del género donde se restringe la lucha a la conquista de una posición para las mujeres, mientras que el feminismo de la diferencia integra todos aquellas personas, etnias o grupos sociales que han sido invisibilizados por el aparato simbólico de la cultura.

Así que rastreamos las categorías de mujer, lo femenino y la literatura femenina en el marco de significados éticos y filosóficos que tienen que ver con la situación antropológica de los dos sexos, pero sobre todo con la realidad cultural de una sociedad que asienta sus principios sobre diferencias meramente convencionales entre lo público/lo privado, lo afectivo/lo racional, la paternidad/la maternidad, lenguajes orales/lenguajes escritos, y que concentran las prácticas masculinas alrededor de uno de los elementos de cada pareja de oposiciones y las prácticas femeninas alrededor del otro elemento. Esta opción nos llevó a la consideración sobre la posibilidad de una ética femenina y la función deconstructiva que ella tendría en nuestro universo social organizado según patrones patriarcales. De hecho, esta opción tendrá que llevar a consideraciones sobre la existencia de un proyecto de realización de lo humano desde formas femeninas, de abordaje de mundo con los significados que las mujeres dan al tiempo, al espacio, al yo, al otro, y a lo que debe ser la existencia social en general, haciendo explícito el rol de la afectividad, la solidaridad, el cuidado de la vida y la protección. De igual manera, la aceptación de lo heterogéneo y lo diferente, así como la posibilidad de usar criterios provenientes de los mundos concretos singulares vendrían a ser estrategias posibles al lado de las consideraciones formales y absolutas de la modernidad patriarcal.

La posibilidad de la existencia de un proyecto de construcción de humanidad según una visión femenina de mundo no se agotaría en proponer una lucha entre los sexos o en la denuncia de la exclusión y violencia que viven las mujeres, sino que buscaría 
que esa visión de mundo opere significativamente dentro del orden androcéntrico y patriarcal. Es verdad que, en los comienzos de la cultura, como existencia social de la especie, pudo existir un serio enfrentamiento entre los sexos, una separación de los roles, una comprensión de los comportamientos vitales de los seres humanos y por supuesto, una representación discursiva de lo que significaban la asociación, la cooperación y la lucha para definir y mantener las diferencias sexuales dentro de las comunidades.

De manera inconsciente, el proyecto de vida de las mujeres y su maternidad siguió siendo asunto de determinación biológica, mientras que el proyecto de vida de los hombres y su paternidad se planteó como el asunto primordial de la cultura. Este proceso descrito por Rubí de María Gómez Campos (2013, pp. 46-47) comentando un texto de Helen Fisher desembocó en la creación de un linaje de herencia patrilineal que se impuso como comienzo efectivo de la Historia de la humanidad. Como correlato de esa dirección cultural, a lo largo del tiempo aparecieron grandes narraciones, que se decantaron en los llamados géneros mayores de la literatura y la filosofía, lenguajes altamente codificados como la retórica y la escritura gramatical, metáforas para el buen gobierno como la del pastor o el capitán de una nave, expresiones conservadas y replicadas al servicio del orden patriarcal. Sin embargo, la dirección masculina de la cultura llevó a extremos nocivos los comportamientos propios de su naturaleza viril: situación de apropiación del mundo, gobernabilidad y ordenamientos jurídicos basados en la exclusión, pues en el imaginario público se fue exaltando la imagen de una sociedad compuesta por miembros ideales en cuanto a autonomía moral y suficiencia de facultades físicas e intelectuales, exceso de racionalización en los modelos sociales, el hiperdesarrollo de la tecnología como objetivo crucial de la ciencia para la apropiación y dominio de la naturaleza. Esta valoración encuentra su contracara en la subvaloración de lo que no se comporta idealmente, pues produce experiencias de mundo de segundo orden, cuyos significados se hacen problemáticos dentro de los lenguajes corriente y así lo expresa Hélène Cixous: 
Predecir qué sucederá con la diferencia sexual dentro de un tiempo otro (¿dos o trescientos años?) es imposible. Pero no hay que engañarse: hombres y mujeres están atrapados en una red de determinaciones culturales milenarias de una complejidad prácticamente inanalizables: no se puede seguir hablando de "la mujer" ni "del hombre" sin quedar atrapados en la tramoya de un escenario ideológico en el que la multiplicidad de relaciones, imágenes, reflejos, mitos, identificaciones transforma, deforma, altera sin cesar el imaginario de cada cual y, de antemano, hace caduca toda conceptualización. (Cixous, 1979, p.42)

Sin embargo, la literatura propia de las autoras del corpus, de alguna manera exhibe rasgos de una experiencia vital en narraciones cargadas de emotividad, por un lado, y por otro lado, cargadas de significado en cuanto efectúan la tarea de expresar su propio proyecto de humanidad. Todo lo que fue dejado al margen de los relatos oficiales de la cultura junto a esa mujer arrojada del centro cultural y sus modos de proceder, son lo que, pensamos, aparece de una forma u otra en la literatura femenina, no sólo como escritura autobiográfica sobre su condición de oprimida, sino como depositaria de unas formas de hacer y de ver que conducen a una propuesta ética para concebir la humanidad. Es esta propuesta ética la que trataremos de rastrear en algunos textos de escritoras latinoamericanas como los de Laura Montoya, María Teresa Andruetto, Wendy Guerra, Alba Lucía Ángel, María Fernanda Trías, Elena Poniatowska, Patricia Nieto, Patricia Lara, Laura Restrepo.

Aunque resulta común hoy, encontrar mujeres con grado académico vinculadas exitosamente a la producción mercantil o involucradas en la guerra y la política, y aunque puede haber un correlato literario para estas mujeres que desempeñan roles tradicionalmente masculinos -Genoveva Alcocer, por ejemplolo cierto, es que, como investigadoras sobre la literatura de las mujeres y sus lenguajes, nosotras, más que reflexionar acerca de las potencias y capacidades para realizar tareas de fuerza y dirección, o abogar por una igualación al varón, debemos reflexionar sobre 
un orden femenino propuesto por mujeres de manera tímida o abierta pero persistente, nacido de la experiencia femenina del mundo, tal vez muy replegada al ámbito de lo cotidiano, pero que como toda experiencia significativa es capaz de convertir esa práctica en discurso y específicamente en texto literario. El orden femenino no sólo corresponde a la sabiduría para administrar las dimensiones privadas de la existencia, sino que también se constituye en una reivindicación, una resistencia a la dominación del varón y una crítica pasiva a las creencias que legitiman tal dominación. Gómez Campos lo manifiesta de la siguiente manera:

Nosotras sostenemos que la mujer actúa en el ámbito familiar (que, según las definiciones de la cultura patriarcal, le corresponde), de dos maneras: sosteniendo y reforzando el sistema patriarcal, pero también y simultáneamente distinguiéndose de él y combatiéndolo subrepticiamente en tanto expresión de un proyecto existencial que le es opuesto. (Gómez Campos, 2013, p. 53)

Por otro lado, como un segundo asunto de la literatura escrita por mujeres está el problema de la representación del cuerpo femenino, pues de una parte ha sido su capacidad para la reproducción, la base de la opresión patriarcal de la mujer, pero, por otro, desde el plano de las realizaciones culturales como la religión, la filosofía o la política, éstas han sido excluidas por la condición sexual de sus cuerpos, lo cual las ha convertido -en términos de lógica falocéntrica- en prisioneras del cuerpo menos dotadas para el pensamiento y la reflexión que los varones. No es entonces sólo el asunto de la maternidad, pues ya desde mediados del siglo XX con la aparición de los anticonceptivos feminidad y maternidad se encuentran separadas. La maternidad ha venido a ser una decisión antes que una obligación y pese a ello, la violencia física y simbólica del hombre sobre la mujer persiste, lo cual indica que lo femenino se relaciona con otros aspectos que van más allá de la reproducción biológica.

Por eso, aunque resulta importante una reflexión sobre el cuerpo, la sexualidad y el placer erótico de la mujer, debemos 
hacerlo en el marco de las relaciones de poder y del dominio, para comprender aspectos de la feminidad y la influencia de estos en un proyecto femenino sobre dignidad humana. En nuestra discusión, el hecho de que la mujer haya logrado separarse de la finalidad biológica de la reproducción, la faculta para situarse como sujeto cultural a la par que el varón y por ende capaz de erigirse en sujeto consciente que puede, o bien, apoyar el proyecto de humanidad racional y belicoso de los varones o, bien, criticarlo y enriquecerlo con las herramientas femeninas desarrolladas a lo largo de siglos de evolución y dominación patriarcal. Sin embargo, el cuerpo debe ser pensado en otro sentido: el de la sensibilidad y la afectividad que convoca potencias humanas distintas de las meramente intelectivas. Siguiendo con Gómez Campos, así lo manifiesta:

Tanto si se concibe a la mujer como un ser con las mismas aspiraciones, concepciones y proyectos del varón (tesis igualitaria), como si se concibe como un ser diferencial que encuentra en el varón lo que ella no es (postura diferencialista), la mujer se define por oposición a éste como defensora de la vida y cuidadora de la especie". (Gómez Campos, 2013, p.52)

En esta afirmación de la autora sustentamos la indagación del canon, pues ahí reside la posibilidad de encontrar vías efectivas de realización femenina para proyectar el discurso hacia una propuesta de humanidad que inevitablemente formulará una crítica al proyecto masculino de existencia, pues hasta ahora no incluye estos aspectos sobre la vida y su cuidado. Sin embargo, la crítica femenina debe superar la pura diferencia biológica. A ella debemos añadirle la diferencia cultural que se origina en la exclusión de ciertas posiciones y roles, lo que se traduce en un universo simbólico de no subjetividad o no lugar para la mujer.

En el caso, en el que las mujeres, como colectivo, se asumen con un proyecto de humanidad propio, podría hablarse de una ética femenina que intenta adjudicar el calificativo de virtudes para la vida buena, a las características propias del modo de existencia 
típicamente femenino. Tales virtudes provendrían, primero, del hecho de su rol histórico en la maternidad y el cuidado de las crías y la familia; segundo, de la conciencia de su cuerpo, su sexo, sus ciclos hormonales y emocionales y, tercero, de las peculiaridades de los lenguajes privados que ellas han dominado a lo largo de los siglos. La compasión, la ternura, la solidaridad, la empatía y el buen consejo hacen parte de ese repertorio de virtudes y sitúan esta ética femenina en la proximidad de una ética basada en el reconocimiento de la dependencia y la vulnerabilidad como la propuesta de Alasdair MacIntyre dentro de la que se plantea la identidad humana como básicamente corporal.

Muy distintas son estas virtudes de las de la ética racionalista patriarcal basada en el reconocimiento de la moral como un compendio de actuaciones diseñadas formalmente y orientadas a la posibilidad de asumir conductas válidas y pertinentes en cualquier contexto vital. Lo bueno no nombra un conjunto extenso de virtudes en las que se enumeren cualidades. Simplemente lo bueno nombra la buena voluntad que se inclina hacia algo formal y vacío que se llama el deber. A su vez el deber, es una categoría definida racionalmente en la que no caben las consideraciones sobre la autoridad, las buenas costumbres, la felicidad u otros criterios parecidos. Se trata más bien de un balanceo entre fines y medios para llegar a ciertos objetivos. Viene al caso aclarar que, desde el siglo XVII, con la instauración de la era moderna, este balanceo de fines y medios es de exclusiva determinación racional. O lo que es más grave, determinada por un conjunto de metáforas y referentes ofrecidos por las semánticas economicistas.

Más que una ética de tipo formal que apenas deja en claro la oposición a las éticas patriarcales de corte racionalista, creemos que las mujeres tienen un proyecto ético que gira en torno al reclamo por el reconocimiento y reciprocidad en la diferencia. También el reclamo por el reconocimiento de que las virtudes concretas propias de la experiencia de mundo y la sexualidad de las mujeres son virtudes propias de la especie y valiosas 
culturalmente. Necesitamos dejar clara la cuestión dado que la literatura escrita por mujeres analizada en el presente trabajo lleva la marca de ese proyecto femenino de humanización.

Decir que la ética femenina debe ser una ética mínima de sobrevivencia, de tácticas diseñadas para la resistencia, o un anexo sobre la reciprocidad que debe acompañar el valor ético de la autonomía, no es suficiente, porque un proyecto así diseñado se mantendría en el campo de las consideraciones culturales sin arraigo en la corporalidad y la biología. Una visión ética que cobije a la mujer debe partir del hecho de que la relación de ella con el mundo, al mismo tiempo que tarea cultural, es tarea en torno al cuerpo, no porque esté dotada de cuerpo y ausente de capacidades espirituales o intelectuales, sino porque como bien lo expresa Alasdair MacIntyre (1999) en su libro Animales racionales $y$ dependientes. Por qué los seres humanos necesitamos las virtudes, es la conciencia sobre la corporalidad animal y la vulnerabilidad y dependencia resultantes de tal condición lo que nos instala como seres sociales capaces de comportamiento ético hacia los demás. En este orden de ideas, las mujeres tienen mucho que decir porque la cultura patriarcal las mantuvo excluidas y las conminó a desarrollar una conciencia de sí mismas justamente a través de la sexualidad y la maternidad.

\subsection{Una ética de la vulnerabilidad y la dependencia}

Alasdair MacIntyre en su libro Tras la virtud (2001) enumera tres aspectos fundamentales sobre los cuales asentar una ética: Quién es el yo que actúa o quién es el agente moral, cuáles son las ideas de bien o cuales son las reglas de comportamiento de una comunidad a la que el agente pertenece $y$, finalmente, en qué entorno o contexto debe practicarse el bien. Esto incluye un repertorio de historias acerca de la vida buena, un repertorio de vidas ejemplares sobre las cuales discutir las situaciones y además la comprensión de que hay momentos críticos, revoluciones o cambios culturales que obligan a que todo lo aprendido como ético 
o moral se transforme y evolucione adaptativamente. El mayor problema en esta trilogía es el concepto de agente moral, pues se necesita, además de ser un actuante con finalidades concretas, gozar de autonomía de juicio y libertad para poner en escena sus criterios. Un ejemplo de la dificultad aparece cuando pensamos en la legitimidad de una agencia moral que se proyecta desde la feminidad: ¿De qué manera una mujer puede ser agente moral cuando no se le reconoce autonomía ni libertad?.

El mismo MacIntyre construye sus reflexiones sobre la virtud no tanto a partir de lo que la ética y la moral deben ser, sino precisamente a partir de la concepción del ser humano como animal cuya racionalidad se asienta en la sociabilidad. Comienza por reevaluar el significado de la animalidad reconociendo a otras especies animales como los delfines, los lobos, los perros, los chimpancés o los gorilas, una racionalidad que involucra creencias y acciones razonadas dependientes de la naturaleza de su nexo social. Estos animales, igual que el hombre, asumen comportamientos de compasión, colaboración, reconocimiento de intenciones y jerarquías, lo cual permite asumir que, como resultado de ello, también pueden desarrollar capacidad para los razonamientos prácticos. Sobre esas capacidades comunes y concretas, el ser humano, mediante un agregado lingüístico, construirá su edificio ético formal y desde estas premisas nos encontramos con uno de sus planteamientos básicos de su propuesta ética:

Las equivocaciones de Descartes se refieren tanto a los seres humanos como a los animales no humanos, y tienen su origen en la convicción de que las ideas que los humanos se forman sobre los pensamientos, sentimientos y decisiones de los demás están basadas, enteramente, en inferencias a partir de su conducta y expresiones manifiestas. Es cierto que a veces es necesario "conjeturar" por inferencia lo que otra persona piensa o siente; pero incluso en esos casos existe el apoyo de un conocimiento interpretativo primario y fundamental de los pensamientos y sentimientos de los demás, que ni tiene una justificación inferencial 
ni la necesita. ¿Qué tipo de conocimiento es este? Es una forma de conocimiento práctico, un saber cómo interpretar, que se deriva de las interacciones sociales complejas, donde nuestras reacciones ante los demás y sus reacciones ante nuestras reacciones generan un reconocimiento por ambas partes de los pensamientos y los sentimientos a los que cada quien está respondiendo. Por supuesto, todos podemos cometer errores alguna vez, pero la capacidad misma para identificar dichos errores supone la facultad de percibir conscientemente lo que los demás piensan y sienten. La comprensión interpretativa de los otros, deriva del contacto con ellos y es inseparable de ese contacto. (MacIntyre, 1999, p. 28)

Las mujeres han desarrollado su proyecto de vida de cara al reconocimiento de la vulnerabilidad y la dependencia pues normalmente sobre ellas recae el cuidado de los niños y la familia, pero también de los enfermos y los ancianos. Si bien los médicos y otros profesionales de la salud conocen y manejan la enfermedad, son las enfermeras quienes tratan y manejan a los pacientes. Para ellas no es necesario la reelaboración del universo lógico de las inferencias para saber cómo actuar en ausencia de un lenguaje explícito sobre el dolor o el sufrimiento. Naturalmente se orientan desde su corporalidad básica de manera sensible y empática hacia el otro, y esperan que el otro actúe de la misma manera. Ese conocimiento es básico cuando se trata del cuidado y la supervivencia de los bebés que, al menos hasta ahora, ha estado a cargo de madres, madrinas y abuelas. La ciencia médica, desde el repertorio de criterios puramente racionales pretende regular la relación madre-hijo, la alimentación, los ciclos de sueño y otros asuntos, pero no podemos negar que, en ausencia de tales prescripciones, las madres saben obedecer instintivamente a la naturaleza y lograr el adecuado desarrollo de sus crías.

La visión de mundo y la visión de humanidad de las mujeres está mediada por sus experiencias, tanto biológicas como culturales y por ello, revisamos la literatura escrita por mujeres buscando tanto en el lenguaje, como en el estilo y la trama, los indicios de lo que hemos llamado proyecto femenino de humanidad o ética 
femenina. Creemos que las marcas del estilo, las metáforas, la forma de las frases, las estrategias narrativas o los diálogos dejarán ver que las mujeres poseen un proyecto de humanidad propio que vincula virtudes provenientes de su experiencia de mundo en el ámbito privado como forma de estar socialmente y hacer frente a los problemas de la convivencia y el desarrollo de la subjetividad. Al respecto Gómez Campos nos deja leer:

La mujer introduce en el mundo la feminidad y con ella se expresa el caos, la locura del mundo, el trastocamiento de los valores de la racionalidad y el rendimiento. La mujer subvierte al mundo en la medida de su banalidad, exhibe su falta de respeto al orden patriarcal mostrándole otra manera de ver y de vivir el mundo; la otra cara de la tierra (Gómez Campos, 2013, p. 61)

El hecho de que las mujeres se evalúen por sí mismas desde una perspectiva más propia, sin tener la influencia de esa ideología dominante identificada como patriarcado, se logra activar la pluma para provocar el deseo de luchar contra sus silencios, en procura de un proyecto femenino.

\subsection{La antiepicidad como rasgo ético de la literatura escrita por mujeres}

Desde hace mucho tiempo, la literatura ha renunciado al sueño de poder ser a la vez ficción y discurso de contenido realista. De hecho, lo importante es descubrir en cada autor sus estrategias para mantener la tensión entre ficción y realidad, de modo que el lector no pueda más que por una postura consciente identificarse con los personajes del relato y colegir que se mueven en una realidad parecida a la suya. El autor crea una anécdota con más o menos visos de realidad para fabricar una narración, pero en verdad el problema del escritor es el punto de vista con el que construye el relato. No son las situaciones ni los asuntos de la trama los que mejor pueden dar las claves sobre el problema de dar sentido a la ficción. Es más que todo el lenguaje y los mundos que ese particular lenguaje permite abrir, lo que le hace accesible 
al lector el universo de creencias del autor, sus convicciones y sus posiciones frente al mundo.

A partir del lenguaje se intuye la virilidad o la feminidad del autor, su preferencia política, sus formas de valorar el mundo circundante y, por tanto, la escritura se convierte en una propuesta de visión de mundo que resulta compatible o no con la del lector. Pero lo que también importa a un autor(a) es que relatar tenga un sentido, que opere como forma de discurso que es necesario desplegar porque lo dicho es lo justo para que el lector crea que el personaje posee herramientas para tomar una decisión o asumir un comportamiento de la forma más prudente posible. De cierto modo, para que pueda actuar como el personaje, si le fuese posible estar en su lugar. El personaje actúa de manera prudente porque sólo él -por su experiencia singular- sabe algo que nadie más sabía. Algo que no está en la luz del discurso porque no puede captarse con una oración gramatical o una sentencia. Sin embargo, el lector intuye que el autor conoce las razones para actuar de su personaje y las comunica aprovechando la suficiencia de los circuitos de la comunicación. Tal suficiencia viene de la conversación, del conocimiento de las situaciones en las que lo dicho no agota ni el sentido ni el propósito de hablar con otros.

En el texto escrito, se establece una complicidad entre lector y autor, un pacto de veridicción que proviene de la natural solidaridad entre el hablante y el oyente de la conversación, y en ellos prevalece la convicción profunda de que comunicarse es necesario para compartir experiencias y desplegar la común expectativa que va configurando identificaciones y filiaciones. La pragmática considera que frente a los discursos se generan comportamientos lingüísticos y por ello es posible pensar que el conducirse de manera empática hay una relación que no deja todos los significados a cargo de las reglas de la construcción lingüística gramaticalmente conformada, ya que se trata de la voluntad de llevar adelante un proyecto existencial conjunto en la confianza de que cada quien tomará una parte en ello. Más contundente resulta ser la siguiente afirmación: 
Cuando nos definimos por nuestra capacidad de usar la razón y el entendimiento estamos expresando que fijamos la capacidad racional, más que la capacidad de sentir, como el marco de las características que nos distinguen. La capacidad de sentir es la que compartimos con animales que no hablan, como los gatos; se trata de estar atento en el sentido de estar despierto. La capacidad de sentir, que es un fenómeno biológico por lo que sabemos hasta ahora, debe distinguirse, a su vez, de la pura reacción de diferenciación fiable que los seres sensibles compartimos con artefactos tales como termostatos y minas antipersona. La capacidad racional concierne al entendimiento o a la inteligencia más que a la irritabilidad o la excitabilidad. Se trata a alguien como capaz de razón en la medida en que explica su comportamiento atribuyéndolo a estados intencionales como convicciones y deseos que constituyen las razones de dicho comportamiento. (Brandon, 2005, p. 39)

Si constatamos que, en la conversación cotidiana entre personas, y más entre mujeres, lo importante no es solo lo dicho de manera explícita, sino las señales de la sinceridad del mensaje, las marcas de la intención y los sentimientos que se vehiculan en el habla, podemos esperar que en los textos escritos por ellas aparezca el nivel de sinceridad, ansiedad y afectividad que son propios de su feminidad. Los textos literarios son los que mejor permiten la expresión de estos elementos que a la larga podrán convertirse en herramientas idiomáticas o dispositivos para vehicular una característica de la escritura a la que daremos el nombre de antiepicidad. Esta característica vincula las intenciones de las autoras con sus lenguajes y el modo en que los personajes de sus ficciones construyen su yo, su proyecto de vida y el modo como expresan sus razones para actuar.

La palabra épico proviene del latín epicus, que a su vez viene del griego epikós, de epos que significa canto, palabra, discurso, epopeya, poema. Se remonta al indoeuropeo wekw-os- "palabra, vocablo", de weku "hablar" + os que es un sufijo que forma sustantivos a partir de verbos. Épico y voz pertenecen a la misma 
línea semántica, de donde podemos interpretar que al agregar el prefijo anti al vocablo épico compondremos un significado en relación con lo que no tiene voz. De otra parte, cuando buscamos el significado de epopeya, vemos el vocablo compuesto epo, palabra y poiía, hacer o crear, crear con la palabra y se refiere al poema narrativo largo que celebra episodios de la tradición heroica de un pueblo. La antiepicidad configuraría un campo en el que se examinan los discursos inaudibles, las palabras y formas que no encuentran sentido dentro del conjunto habitual de los significados presentes en la tradición literaria o el canon oficial.

Por antiepicidad vamos a entender en este trabajo una propiedad de la escritura que penetra en lo incierto de temas y asuntos que, sin estar claramente establecidos, pueden entrar en la memoria como cosas importantes para recordar. Se trata de una categoría que da cuenta del desajuste o malestar del narrador de una historia cuando ordena los asuntos de su relato para ser compartidos con otros. La utilidad de la categoría aparece cuando permite ver un vínculo entre el punto de vista del narrador y una manera de situarse dentro del entorno cultural, es decir, cuando vincula el lenguaje con la identidad cultural. Cuando hablamos de antiepicidad, nos referimos a una forma narrativa que puede asociarse al paradigma de lo femenino, pero también a la escritura de la subalternidad, las tácticas de los débiles de las que habla Michel de Certeau y otras formas literarias que dejan de lado las consideraciones modernas sobre canon literario, lenguajes y temas para explorar voces y desde ellas construir ficciones que visibilicen los mundos posibles a partir de esos registros lingüísticos.

En el caso de la literatura escrita por mujeres, creemos que el recurso a la experiencia de lo cotidiano en la creación de temas y lenguajes entra como característica de la antiepicidad, una categoría que diseñamos para aludir a la ausencia de voces femeninas en el canon literario de Occidente, al menos hasta la contemporaneidad. Lo antiépico aparece en torno a lo femenino, pero también en torno a obras escritas por quienes han sido 
arrojados a las márgenes culturales, sean hombres o mujeres que aún no tienen nombres normativizados y legitimados para sus creencias y sentimientos, sino que deben mantenerse implícitos en las formas de describir los eventos y entornos circundantes.

Dice Antonio Dueñas en su ensayo Leer en femenino que existen un cúmulo de novelas que leen las mujeres y que los hombres en general ignoran. Para este autor esas novelas "lejanas de la épica y de la acción idealizada, más centradas en el interior de los personajes (con todos los clichés propios de la época) conducen a circunscribir y etiquetar la novela con el sello de lo femenino" (Arizmendi y Arbona, 2008, p. 152).

Describe el autor la situación en la que la educación para la acción y la decisión de los varones no se compadece con los universos de ficción antiépicos en los que son frecuentes la duda, el balbuceo, la vulnerabilidad de los personajes, la paradoja y las múltiples perspectivas que lejos de permitir $y$ fomentar las posturas técnicas y positivas de los hombres, terminan por conducir a la inactividad. La introspección, técnica favorecida en el conjunto general de la novelística, conduce a los hombres a una imagen acabada de sí donde existe claridad sobre quién es el sujeto, y con qué herramientas se enfrenta al mundo. A las mujeres, en cambio, las conduce a imágenes inacabadas donde no hay herramientas confiables, sino que se trata más bien de establecer una relación empática entre las personas (o los personajes) y su mundo.

Géneros narrativos inspirados en la épica podrían contener y poner límites a novelas cuyos personajes vivieran más en acuerdo con el corazón que con la razón, puesto que en ellos priman las consideraciones sobre el proyecto de humanidad que sería justamente lo que la literatura épica tiene a su favor: poner en forma de trama un proyecto racionalmente trazado. La épica sería el arte de crear un personaje que encarne los supremos valores de la cultura y los haga prevalecer sobre cualquier vicisitud o contingencia humana. Históricamente la épica se corresponde con 
el desarrollo de géneros narrativos que, si bien se conformaron dentro de la oralidad, escriturariamente llegaron a nosotros provistos de un formato lingüístico que los acartonaba al punto de no poder comunicar, como dice Benjamin (1991), aquello que está en la experiencia humana. La finalidad de estas obras es la de hacer legible, de manera explicativa, las acciones de los personajes de tal forma que se comprendan como un encadenamiento lógico entre causas y consecuencias. Legibles en el sentido de responder a un cierto punto de vista, un orden discursivo y un lenguaje pertinente para ejemplificar la adopción de valores occidentales por parte de un sujeto real dentro de una forma de existencia posible para él. De esto se tratan las narraciones en general, épicas o no, pero en el caso de la novela como género épico, la historia debe, además, poder encajarse entre los límites impuestos por el libro. Crearse como historia con principio y final de manera que en la última página se cierre un ciclo y triunfen ciertos valores sobre otros.

La tensión entre protagonista y antagonista se presenta de modo tal que el lector termina identificándose con el protagonista. Pero la pregunta prevalece. ¿Basta la identificación? ¿Ese impulso psicológico de asumir el protagonista como el otro yo, basta? Las formas de la lectura moderna conducen a la identificación, pero olvidan que en ello va más que los rasgos de la personalidad y los sentimientos. También van los valores sociales y culturales. Mientras la novela sea una oportunidad para examinarlos de manera crítica, la lectura estará cumpliendo con su papel de autoconocimiento. Pero mientras la novela sea un dispositivo cultural que usa la identificación psicológica como gancho para el aleccionamiento moral de los valores en boga, la novela tendrá el impulso épico en el que triunfa un determinado tipo social representado por un personaje que se parece a cada uno de nosotros: está carente de algo y lo consigue; es inocente y aprende; está solo y logra compañía; lo demás se calla y se naturaliza. Sin ser mencionado, el tema cultural de base cumple la función de aleccionamiento porque al estar naturalizado no necesitan leerse de manera explícita. 
La palabra "épica" en este trabajo ostenta un significado en relación con el poder, pues en las narraciones que pertenecen a esta categoría, hay un uso político del lenguaje y la literatura y, por ello, las novelas aparecen como dispositivo al servicio de las lógicas más básicas del dominio y la exclusión, en las que los seres humanos se sitúan de frente al mundo para cosificarlo y descifrarlo en acuerdo con leyes que a fuerza de repetirse terminan por naturalizarse. La epicidad como característica de las literaturas canónicas de occidente se refiere a aquellas novelas y relatos en los que prima la acción idealizada como combate en el que sólo uno de los implicados triunfará. Dicho de otra manera, es una literatura que encarna los valores legítimos, pero arbitrarios, de un grupo de individuos que se dan un orden como colectividad.

Aunque los personajes viven y sienten, ellos normalmente cumplen una función de agentes o representantes de un cierto ordenamiento social de donde resulta que los factores externos a la subjetividad priman sobre las problemáticas referidas al interior. No sobra decir que en distintas latitudes y distintos momentos de la historia, las formas de lo épico varían, pues la fuerza de las normas, las distancias jerárquicas, así como las creencias y poder de los discursos tienen diferente grado y alcance. No son iguales, entonces, el personaje de María en la novela de Jorge Isaacs donde María no toma decisiones ni actúa en ningún sentido verdaderamente propio porque además de estar sometida como mujer a los esquemas patriarcales, tiene en su contra su falta de horizonte vital, y el personaje de Emma Bovary de Flaubert, quien tiene claro el plano de sus deseos propios y su necesidad de escapar al destino y que está dotada de la capacidad de actuar como mujer rebelde a las exigencias de su tiempo. Sin embargo, ambas mujeres mueren sin lograr triunfar sobre la adversidad.

Tal vez un modo de decirlo de manera contundente, desde la filosofía, sería afirmando con Heidegger (1998) "que los hombres son capaces de transferir la estructura del lenguaje proposicional a la estructura de la propia cosa" (p. 14). Esto implica que dentro 
de la epicidad hay una voluntad de hacer prevalecer una forma de ver que se impone sobre los acontecimientos para decir que esta forma de ver da cuenta de lo real, lo examina, lo contrasta y lo convierte en saber que se registra en diversos géneros escritos como filosofía o literatura. De ahí que esos textos se erijan en modelo de mundo social, no solo en sus contenidos específicos, sino también en la forma lingüística proposicional que usan para dar forma al discurso. Pero no es válido para el universo femenino en el que no hay potencia para ser adversarias del poder cualquiera que sea su origen.

Asociada a la epicidad se encuentran otras exigencias en relación con el lenguaje en el que las acciones heroicas se expresan, pues, aunque las epopeyas son anteriores a la invención de la escritura, ellas se componen y estructuran como un texto escrito que terminan por exhibir rasgos escriturales ya que su forma literaria llegó a nosotros mediada por la visión de poetas que dominaban la escritura. Walter Ong (1999) ha estudiado el problema acerca de cómo los poemas épicos orales terminaron por ajustarse a las exigencias de la escritura: "En el pasado, la exégesis de la epopeya oral realizada por quienes conocían la escritura generalmente consideró que los poetas épicos orales hacían lo mismo, y les atribuyó una desviación consciente de una organización que en realidad era imposible sin la escritura" (p.140). A pesar de que la épica es un género oral, contribuyó a transformar la mentalidad de los espectadores y los autores según una organización lógica del sentido obtenida a su vez de la organización cronológica de los acontecimientos que la escritura hacía posible. Ninguna experiencia, después de la épica fue posible sin esta concepción de proyecto narrativo en torno a la sucesión temporal del antes y el después.

De este último asunto se desprende una consideración más y es precisamente la falta de tradición escritural en la educación femenina. Virginia Woolf (1981), expresó en Las mujeres y la literatura que la oración (gramaticalmente constituida, con valor 
lógico y orden complejo) es una construcción masculina. No le faltaba razón, pues el acceso a la educación escolar y el aprendizaje de la escritura era un asunto mayormente de hombres. Las mujeres sabían leer y escribir, pero los textos a los que se enfrentaban estaban dedicados a la religiosidad y el universo de las prácticas domésticas más algo de historia y geografía. Para ello bastaba la expresión simple con oraciones también simples muy cercanas a la oralidad. Y aunque las mujeres de hoy acceden a los centros universitarios y se mueven de manera solvente en escenarios académicos, el proyecto vital que comunican a través de la literatura puede seguir exhibiendo bastantes rasgos de oralidad, al menos en mayor medida que aquellos escritos por varones.

Finalmente, y todavía en relación con el tema dela antiepicidad, debemos considerar algunos aspectos que van apareciendo en torno a las prácticas lectoras y la recepción de novelas en los últimos tres siglos, pues las mujeres como consumidoras de narraciones han contribuido a la transformación de las prácticas literarias en general, pero particularmente por el hecho de dotar a la novela de potencias en torno a contenidos menos épicos y más intimistas y emocionales. Como lectoras, las mujeres no han parecido estar muy interesadas en el tipo de narraciones sobre acciones épicas, pues a ellas lo que les interesa es precisamente el sentimiento o las vicisitudes del corazón. Es decir, están más interesadas en los motivos de la acción, en sus antecedentes, antes que en la acción misma.

Dice Stefan Bollmann en Mujeres y libros (2015), un ensayo acerca de lo que leen las mujeres, que la lectura como práctica cotidiana data del siglo XVIII y que en este siglo el amor pasó de ser un tema tratado intelectualmente en sus consecuencias, naturaleza o afecciones a ser sentido, por lo que la literatura se transformó en otro tipo de objeto cultural: ser el lugar de la consideración teórica pasó ser el vehículo de emociones y sentimientos que apunta directo al corazón antes que a la mente. No es la información ni los datos lo que se vehicula en el escrito, sino la posibilidad de 
sentir de modos más estructurados y complejos. A lo largo de su texto, Bollmann examina cómo se involucran cada vez más las mujeres en esta práctica y como la práctica misma de la lectura y la escritura avanzó para conquistar terreno y hacer de lo privado algo público. Fue así como ellas hicieron su aparición en la esfera literaria, lo que les daba un peso en la cultura, porque cuando se prendaron de ese tipo de escritos y de ese tipo de lectura colectiva, los editores consideraron válida la opción. Cuando la lectura dejó de ser un ejercicio intelectual y se convirtió en parte de la vida aparecieron los primeros rasgos de antiepicidad en las historias que tendrían que ver con la ausencia de un narrador omnisciente y la anulación del distanciamiento entre el objeto artístico y la vida. No es casual que a estos rasgos se sumen muchas voces femeninas, de tal manera que, en la primera mitad del siglo XIX, las mujeres publicaron con éxito muchas novelas al punto de ser más el número de autoras que el de autores, con la característica adicional de ser escritas pensando en una lectora antes que en un lector.

Uno de los ejemplos citados por Bollmann sobre este hecho es el de Werther de Goethe. La novela amorosa despertó tanta sensibilidad entre los lectores que desencadenó suicidios en jóvenes de ambos sexos, puesto que la literatura se iba convirtiendo en una especie de lectura iluminada cuyos contenidos eran tan válidos como los de cualquier texto sagrado. En cuanto a autoras, la lista comienza con Benedikte Naubert a finales del siglo XVIII quien logró el éxito, a pesar de que el movimiento romántico liderado por Novalis, Shelling o los hermanos Schlegel al ocuparse también del mundo de la vida. Tal vez lo logró, pues mientras ellos se validaban mejor ante la crítica haciendo del descubrimiento íntimo un suceso académico acorde con la idea canónica de que la literatura, más que sentimentalismo debía ser una oportunidad para el descubrimiento de un "yo" propio en consonancia con los "yo" de la referencia cultural. El resultado fue que la producción de las autoras se mantuvo bajo el sello de la inferioridad, aunque existieron obras y editores dispuestos a arriesgarse en una apuesta 
por una literatura escrita por mujeres para el público general. Es verdad que Bollmann discute la situación para comparar escritura femenina y escritura tradicional en escenarios europeos, pero los contenidos de sus argumentos son válidos para nuestra discusión en el marco de lo latinoamericano porque enuncia los cambios, no solo en la sensibilidad de la época, sino en la actividad de las mujeres escritoras.

De todas formas, para nuestra discusión sobre la literatura escrita por mujeres no es importante sólo pensar cuáles fueron los temas preferidos por ellas, si podían tratarlos con la misma profundidad con que eran tratados por autores masculinos, si publicaban más o menos que ellos, si la crítica literaria las maltrataba o las exaltaba. Se trata más bien de entender cómo las mujeres lograron, con su forma de leer y acercarse a los temas, que la literatura virara sus posibilidades de ser un ejercicio intelectual para convertirse en una forma de vida. Es decir, si uno de sus logros como escritoras y lectoras fue el de integrar la literatura a la vida cotidiana como parte de una misma trama.

A comienzos del siglo XX, las mujeres leían novelas de las que aprendían las nuevas opciones que la sociedad tenía para ellas, sin embargo, innegablemente, la escritura de narraciones ha ido evolucionando por influencia femenina hacia la escritura de relatos con gran contenido emotivo en donde lo cotidiano se eleva a la categoría de tema como tal. Sería de esperar que las formas de tratamiento de la cotidianidad no tengan que sufrir los tratamientos que las lógicas patriarcales imponen a los universos humanos. Racionalizar el lenguaje de lo íntimo y dejar en el limbo del sinsentido los asomos de feminidad cuando se tematiza la cotidianidad de las personas. Es la misma situación que expone Benjamin cuando habla de los soldados que volvían enmudecidos de la guerra porque quienes estaban destinados a narrar las batallas eran los escritores profesionales -los que manejaban y anteponían el formato editorial a las historias- y no aquellos que vivieron la experiencia. Es posible que los significados en relación con los 
cuerpos, la comunicación no verbal y el aporte de la emoción a la construcción de las situaciones quiera dejarse en manos de aquellos que lo viven tangencialmente, pero lo cierto es que la mujer escritora y la mujer lectora pueden enriquecer las ficciones a través de estos elementos.

En esta breve historia podemos ver que las mujeres como escritoras y lectoras traen a primer plano el tema de los sentimientos, el amor, sobre todo, y el de las emociones en relación con el erotismo antes que con la reflexión intelectual. Sus creaciones mantienen un enfoque íntimo, con múltiples autorreferencias, con amplia exploración del universo interior de los personajes y elaboraciones discursivas emparentadas con las dinámicas de la oralidad. Al menos las autoras elegidas para nuestro análisis son escritoras involucradas estrechamente con sus temas capaces de deconstruir las referencias objetivas, aún las de tiempo y espacio para expresar la fuerza interior que mantiene vivos a los personajes de sus ficciones. En el lenguaje, abundan los enunciados breves, los cortes, los silencios, el ritmo y la musicalidad de las expresiones. En cuanto a la construcción del yo, la memoria especialmente del tiempo de la infancia y los primeros amores, así como las técnicas para reconocerse en el espejo de las generaciones son los recursos más comunes. Las mujeres protagonistas en estas obras carecen de reconocimiento y carecen de mundo y por eso balbucean cuando se confrontan, dudan cuando toman decisiones y se empequeñecen o se asfixian ante los embates de las reglas de la tradición y la superioridad de otros personajes que hablan desde la autoridad y el poder. El heroísmo de los personajes femeninos creados por estas mujeres reside en la manera en que trata a quien está cerca suyo, aunque implique renuncias a un proyecto de vida propio o aunque implique rozar el borde de la locura. Pero, esto no agota el repertorio de opciones para la escritura femenina. Revisar otras obras puede llevar a otras conclusiones, pues la mujer aventura temas, técnicas y recursos novedosos que no siempre se tendrán que analizar con respecto a su experiencia de mundo. Sin embargo, en este trabajo nos enfocamos en ella, pues creemos que 
precisamente esa experiencia constituye un fondo de recursos semánticos para enderezar un proyecto de humanidad de origen patriarcal que se ha venido revelando insuficiente y hasta nocivo para preservar la vida humana en nuestro planeta.

A lo largo del trabajo iremos mostrando cómo cada una de las autoras logra que sus personajes compartan con los lectores el universo de los afectos, como pueden sustraerse a los juicios intelectuales, tratando de hacer de la vivencia la explicación suficiente para los acontecimientos, y donde los valores exhibidos lo son en cuanto ponen en marcha decisiones legítimas para sostener el orden concreto antes que para legitimar el universo de las creencias paradigmáticas. 



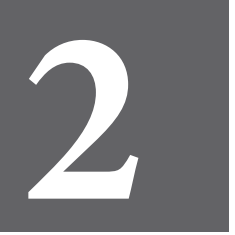

CAPÍTULO

DOS 



\section{Procedimientos narrativos antiépicos}

Dos deberes tendría todo verso: comunicar un hecho preciso y tocarnos físicamente, como la cercanía del mar.

Jorge Luis Borges, 1975

\subsection{Una narración antiépica: un caso de no yo}

Aventura Misional de Dabeiba escrito en 1939 por la religiosa antioqueña Laura Montoya Upegui, hoy Santa Laura Montoya, es un texto autobiográfico en el que a lo largo de casi seiscientas páginas su autora nos cuenta cómo logró iniciar una misión indígena en Dabeiba en 1914 y cómo logró sostenerla por 10 años hasta que fue expulsada del territorio. La historia se constituye en un viaje de descubrimiento de las luchas de la Madre Laura no sólo con la desconfianza de los indios o las condiciones de la naturaleza, sino con los prelados de la iglesia que eran sus superiores o que, al menos, debían ser los protectores de la misión. El lector puede percibir claramente esta última contradicción, a pesar de la censura que los diversos capítulos debieron soportar.

En apariencia, la narración tiene la forma de una crónica personal escrita en tercera persona sobre las innumerables peripecias vividas por la comunidad de religiosas en un territorio hostil, pero deseado al mismo tiempo, que comienza cuando 
Laura se inició su apostolado en tierras de indios. Como en todo relato autobiográfico lo que el texto produce es el yo del escritor, la relación con el poder y la cultura de su tiempo, el universo de creencias, pero además de ello este relato produce el yo en relación con las exigencias del rol de Laura como mujer de iglesia ya que no puede decirse que fuera una monja en regla de canonicidad. El "yo" de este relato es colectivo antes que individual, pues no es su objetivo establecer una identidad en particular a medida que la crónica avanza, mucho más por el hecho, ya señalado antes, de que la escritora se refiere a sí misma en tercera persona, sin la más mínima intención de destacar la importancia de su persona. Se ve a sí misma como instrumento de una voluntad muy alta -la divina- y por acción de ella su rol como misionera se mantiene por la capacidad de llevar a cabo las tareas que esa voluntad le impone. Pero la alteridad que alienta en sus actos y en su voz no es únicamente esa, pues en sus palabras también alienta la voz del indio y la de la naturaleza selvática misma. Transita por las palabras como misionera, mujer y criatura de Dios con la total convicción de serlo, pero al mismo tiempo con mucho desapego por sus propias necesidades personales. De hecho, en otro texto suyo, Laura Montoya Upegui: Autobiografía, dice en la introducción. "Así, cuando diga YO, quiero decir: ésta que no es, y cuando diga MI VIDA, quiero decir: esta agonía con la cual es preciso acabar para encontrarla en Ti, vida única." (Montoya, 1971, p.2).

Las mujeres de iglesia, monjas en su mayoría, han escrito por diversas razones, donde la más común es la imposición de sus confesores de llevar un registro de las acciones y pensamientos del subordinado, como forma de autocontrol y desarrollo de la conciencia. Si recurrimos a Foucault con Tecnologías del yo (1990) encontramos cómo la confesión aunque es una técnica que contribuye a la configuración de la conciencia individual también hace parte de los problemas del poder. Cuando un texto se escribe bajo esta modalidad termina por ser un texto complaciente con las necesidades del ente de control. El yo que surge de la confesión es el que se dispone para otro cuando existe 
la necesidad de ser comprendido y perdonado. La confesión no es un discurso espontáneo dentro del cual la conciencia del hablante pueda mostrarse sin tapujos, sino que es un discurso controlado donde el yo aparece como ejecutante de acciones que obedecen a intenciones calibradas dentro de un sistema de valores y creencias. Es así como funciona el relato autobiográfico. Josefa del Castillo o Sor Juana Inés de la Cruz escribieron por mandato de sus confesores y al leer sus biografías no podemos olvidar que la narración tiene un fin público que está en relación con la justificación de desvíos de la regla o la disculpa y humillación por ocurrencias insensatas, antes que un deseo por hacer valer la privacidad del sentimiento o las convicciones íntimas.

En el caso de la biografía de Laura Montoya, un relato anterior al que nos ocupa en este capítulo, que consta de 988 páginas y que fue escrito entre 1925 y 1933 se ajusta a las demandas de lo que es propio escribir para una mujer subordinada al poder. La queja se encubre, la injusticia se legitima o se disculpa, las intenciones se soslayan para que la imagen de los varones de la iglesia se mantenga pulcra, piadosa y correcta. Igual sucede con sus otros libros, pero en el caso de Aventura de Dabeiba, escrito a manera de crónica, sobre la gesta colectiva de su comunidad religiosa, Las Hermanas de Santa Catalina de Siena, en Urabá y Sarare es posible echar un vistazo a la imagen de la misionera y sus afectos verdaderos. Junto a las anécdotas sobre la conquista de almas para la gloria de Dios, la escritora se cuida de narrar aspectos de su subjetividad abierta al otro, tal como se muestra en este fragmento:

Al contrario, la superiora había tenido bien en cuenta el no violentar ni atemorizar los salvajes para nada, y hacerse a sus ideas, mientras que, con procedimientos maternales, podía infundirles las suyas y hacer que las adoptaran razonablemente. Se proponía no usar autoridad seria, sino a medida que iban desalvajizándose, puesto que sólo entonces hay razón para exigirles el cumplimiento de ciertas leyes, de las cuales no se han dado cuenta y que contradicen a sus inclinaciones e instintos naturales y aún adquiridos por el roce con el medio selvático y fiero. (Montoya, 1939, p. 287) 
Este fragmento nos deja ver cómo las acciones y las reflexiones parten de su convicción de que el indígena es menesteroso, que se debe tratar con especial cuidado porque está en condición de inferioridad dentro de la cultura occidental que lo rodea y lo legisla, sólo porque no ha recibido el bautismo. Pero la desventaja es provisional, pues, para ella, estos "otros" son vulnerables sólo hasta el momento en que los sacramentos logren conseguirles un lugar dentro de la comunidad católica, lo que a sus ojos, sería equivalente a un lugar en la sociedad. Es cuestión de que "los libres" se abstengan de explotarlos inmisericordemente porque también tienen alma y son sus semejantes. Sin embargo, la categoría de indio implica la inferioridad para la Iglesia como institución y para el conjunto social representado por el creer y el sentir de los colonos blancos. No así para Montoya. A lo largo del texto narra cómo observa a los indios y aprende sus costumbres, se mezcla e intenta sentir lo que ellos sienten. Los busca para interrogarlos y aprender, no sólo para enseñar y catequizar. Así cuando un indio habla de Dios calificándolo de bruto, la escritora disculpa sus palabras, pues no puede ser blasfemia lo que se dice de manera espontánea sin el conocimiento suficiente: "Sin embargo, cuán lejos estaban esas palabras de ser una blasfemia, como a primera vista se juzgarían." (Montoya, 1939, p. 39).

En otro lugar de la historia nos muestra que los indios tienen universos de creencias diferentes porque hacen parte de mundos diferentes "Porque vais a ver, amados lectores, que estos infelices no tienen los misterios sublimes que en nuestra doctrina católica nos enseña la Santa Iglesia, pero, en cambio, tienen supersticiones, agüeros, ceremonias y maquinaciones secretas que infunden pavor" (Montoya, 1939, p. 139).

Por su crónica sabemos que Laura Montoya usó medicina indígena, asistió a sus ceremonias sagradas, escuchó sus plegarias, respondió sus preguntas, argumentó, les dio tiempo para empezar a creer en el evangelio. Y también se hizo querer por ellos. Venció el recelo hacia el cristianismo y las comunidades libres que se 
acercaban para robar sus tierras y explotarlos. Desde su visión maternal como misionera logró convencerlos de que podían formar parte de una comunidad más amplia a pesar de las diferencias pues a ella le parecía que eran peculiaridades, costumbres que prevalecerían sólo mientras durara la catequización. Es cierto que ella posee una idea sobre el género humano que corresponde a su cultura y a su tiempo, pero tolera las diferencias, le divierten, la enternecen. No tilda de salvajes a los indios en el sentido de enemigos peligrosos que se sitúan en una orilla opuesta de pensamiento.

La perspectiva teórica para nombrar este fenómeno sería la de una ontología relacional en la que la pregunta por el yo se responda con la imagen del quién eres tú, lo cual entraría en correspondencia con la idea de antiepicidad, en la que la propia voz no puede fundar mundo si no está acompañada de otras voces que discrepan y se resisten a las ideas. No es posible dar cuenta del yo que habla en el relato si ese yo no pasa por las transformaciones y reconstrucciones que la situación de vida del otro impone. Y es más útil para nuestro análisis sobre literatura escrita por mujeres partir del hecho de la vulnerabilidad -una condición del cuerpo animal que en el curso de la existencia experimenta dolor, miedo, sufrimiento y finalmente, la muerte- como caracterización de lo humano, a la vez que fundamento de la antiepicidad. Al contrario de la autonomía como punto de partida, la vulnerabilidad nos permite llegar a la conclusión sobre lo que somos, si nos pensamos como miembros de agrupaciones sociales cercanas a las manadas de otras especies de mamíferos. Al mismo tiempo, la vulnerabilidad resulta ser una noción afín a la experiencia femenina del mundo, sensible y afectiva. Alasdair MacIntyre (1999) dice:

No es cuestión sólo de que el cuerpo humano sea un cuerpo animal con la identidad y la consistencia de un cuerpo animal, como ya hemos dicho. La identidad humana es fundamentalmente identidad corporal (aunque no sea sólo corporal) y es, por lo tanto, identidad animal; la consistencia de las relaciones con los demás en parte se define con respecto a esa identidad animal. 
Entre los diferentes males que afligen al ser humano están aquellos que alteran esa consistencia (la pérdida o lesión de la memoria, por ejemplo, o la desfiguración que impide que los demás nos reconozcan), así como aquellas que nos discapacitan de otra forma. (p. 23)

Tal consideración es pertinente para acercarse a la escritura narrativa de Laura Montoya, pues ella se compadece de cada uno de esos congéneres cuando se pone en su lugar y considera su humanidad a partir del dolor que se les inflinge. Cuando se habla de vulnerabilidad en este contexto, la referencia es al cuerpo como sustancia y medio a partir del cual se construye la subjetividad. La afirmación del sí es válida cuando se reclama reconocimiento en medio de conflictos sociales o políticos donde el cuerpo está presente, a través de la problemática de sus relaciones, donde lo que se propone a la decisión es cuáles son las acciones apropiadas, a dónde moverse, a dónde mirar, qué hacer, qué decir, cómo producir encuentro con el otro. El texto nos permite ver que la cercanía de la protagonista con el indio participa de la conciencia de la vulnerabilidad. Su simpatía y compasión hacia ellos pasa por el reconocimiento de sus cuerpos, su cansancio, su forma de vida simple sin tecnología que ofrece esperanza de pausa. Laura Montoya, la superiora, y sus hermanas por igual curan heridas, lavan llagas, alimentan, ofrecen lecho a cuanto indio logran acercar a la Misión.

De otro lado, en el contexto de la antiepicidad está el lenguaje de Laura Montoya, quien en muchas ocasiones encuentra en los refranes y dichos chocarreros formas de expresión más potentes que los enunciados y las proposiciones “ ¿Raro? Más raro que Adán siendo tan blanco, sea el padre de las naciones negras" (Montoya, 1939, p. 785). La sentencia o frase célebre también era común en sus labios y en su pluma: "Si el alma tiende hacia las alturas, busca lo espiritual, lo diáfano, lo divino; el miserable cuerpo tiende hacia abajo, hacia la tierra, hacia los enanos gustos de los sentidos" (MacIntyre, 1999, p. 29). 
También las asociaciones y comparaciones son frecuentes para dar a entender ideas místicas o profanas:

Contemplad, si queréis, un leño que suavemente se desliza por la superficie de un río manso, encauzado a lo largo de un valle. Verdad que el leño llevado por mansas ollas avanza, pero !cuán poco! No hay una fuerza que acelere su paso, y si no viene la época de lluvias, con sus chubascos y crecientes, el leño se puede quedar en el camino sin llegar a su fin". (Montoya, 1939, p. 97)

Decía eso para advertir que el curso de las obras de Dios no siempre se ve seguro en el horizonte. También es frecuente el recurso a la cita bíblica para dar sentido a los acontecimientos de su entorno. Ese dudar del final cierto de los eventos es constante en sus historias y reflexiones. Por ello se da tiempo para considerar estadios previos y una dosis de provisionalidad en el pensamiento y el conocimiento que las personas pueden tener de Dios.

Pequeños diálogos en los que las hermanas adoptan el habla del indio y tratan penetrar el curso de sus ideas detienen nuestra mirada sobre otra lógica de pensamiento, que sin embargo no impide la comunicación.

Hna: U vive muy lejo?

Indio: Onde Pital, pro yo no durme porque como diciendo por dentro on cabeza: ese dios de magre será casao? No puede durmir nada... Antonces yo corriendo venió pa preguntar. Dios casao es? Onde mujer tiene?

Hnas: Dios no es casao porque Dios muy diferente de indio y de gente: todo gente cuerpo tiene, así cun mano, cun cara, cun pata etc. Dios eso no tiene.

Indio: sin mano, sin cara, sin pata. Antonces ese cómo es?

Hna: ese que se llama pensamiento que es como hablando por dentro, tampoco tiene mano, estómago ni cara.

Indio: De vera! De vera!

Hna: Así es Dios como pensamiento (1939, p.64-65) 
Muchos de estos procedimientos estilísticos son cercanos a la oralidad, y aunque tienen la finalidad de hacer fácil el entendimiento de las verdades religiosas, son también usos corrientes en el repertorio de técnicas femeninas de escritura porque de algún modo vuelven más concreto el mundo, lo ponen al alcance de las percepciones directas y de los afectos al mismo tiempo que lo tiñen de subjetividad. A lo largo del texto, las acciones tratadas aparecen desde la inmediatez del hecho, antes que desde la necesidad de crear una estructura con el fin de hacer resaltar alguna idea preconcebida o formalizada. A la autora, no le interesa hacer de sus métodos o de su persona hechos memorables, pues, por el contrario, sabe que no cumple con los requisitos para hacerse con el encomio social. Laura Montoya, como protagonista del relato, rompe las reglas y se vale de tretas para conquistar a los indios, para mantener su comunidad a flote y por tanto no puede resultar una monja ejemplar. En alguna ocasión, huyó con los niños del internado en medio de la noche, fugitiva de sacerdotes que venían a reclamar como propio el esfuerzo de sus monjas.

Su escritura recoge las anécdotas, pero también la disculpa que desde su fibra más interior ofrece a aquellos que obstaculizan sus propósitos. Así, cuando narra los problemas de la Misión en cuanto a lo administrativo se sitúa en un plano ambiguo en el que no señala al enemigo en un claro tono de denuncia y el lector sólo puede adivinar o suponer. Está segura de que las acciones de los poderosos afectan a un gran número de personas: la comunidad embera katío, cuando le niegan auxilios oficiales, por ejemplo; o, peor aún, cuando amenazan con suspender sus plazas de maestras de las que se sostienen económicamente. Pero Laura Montoya sabe también que no debe entrar en señalamientos o en argumentaciones sobre la bondad de quien es desasistido -tal como lo es la incipiente comunidad misionera- o la maldad de quien niega la asistencia -autoridades civiles y eclesiásticas-. Espera con paciencia que los vientos contrarios a su obra se disipen, pues para ella la adversidad es un contratiempo, una prueba de Dios que en algún momento se subsanará. Si recordamos que habla de sí 
misma en tercera persona y como parte del colectivo de religiosas, entenderemos lo que dice.

Poco después de esta inspección, estalló una lucha terrible contra la Misión. Las pésimas influencias de D. Carlos Villegas (q.e.p.d), entonces comisionado del gobierno en Occidente privaron a la Misión de los auxilios departamentales. La noticia dada por gentes de mala intención acerca de las fabulosas riquezas de la obra evangelizadora de Occidente, movieron a D. Rubén Gaviria a retirar la oferta del rancho, en el valle de Murrí. La desmembración de la Diócesis de Antioquia les cerró la esperanza de capellán. ...Todo se había terminado, menos la confianza en que Dios haría surgir nuevos medios, aunque no se vislumbraba de dónde podrían venir. (Montoya, 1939, p. 217)

Así se crea el escenario de la lucha que no responde al arquetipo del bien contra el mal, pese a lidiarse en el seno de las creencias religiosas. Tampoco corresponde al arquetipo de construcción de historias sobre situación inicial el planteamiento de una carencia implementación de plan de acción y resolución de la carencia. La historia se va desplegando alrededor de hechos realmente misteriosos y sorpresivos que hacen imposible una única línea de desarrollo o una sola serie de eventos relacionados por algunas causas y sus efectos. La iglesia, para el caso de las monjas, ha inventado la figura del confesor, el coadjutor, el director espiritual para controlar la voz y el cuerpo de la monja. Para mantenerla vigilada y controlada en la medida en que ella va haciéndose dueña de la escritura. No era necesario que todas las monjas supieran leer y escribir, pero aquellas que aprendieron debían ser controladas. Y no solo en la institución conventual se ha vigilado la escritura de las mujeres. En el campo literario en general, la crítica masculina ha cuidado que la participación femenina en el canon no desborde ciertos parámetros. Bollmann, autor de un texto reciente sobre escritura femenina, asume la vigencia de tácticas de control masculino sobre las obras femeninas: 
La supresión de las obras literarias de las mujeres era el resultado de una estrategia de los hombres, que en calidad de críticos y desde el cuadro de profesores de las universidades empezaron a determinar qué literatura era seria y cuál únicamente amena, cuál era canónica y cuál efímera. (Bollmann, 2015, p.123)

Hasta mediados del Siglo XX, las escritoras eran conscientes de que se movían en un territorio extraño, y algunas de ellas asumían la escritura de manera ingenua, sin haber intentado la pregunta por la relación entre lenguaje y vida, como si el lenguaje fuera un único cuerpo un único instrumento de un pensamiento universal y vertían a través de él su vida interior, sus pensamientos, como si no concibieran una intención comunicativa por fuera de la regla representacional. Otras autoras convirtieron la práctica de la escritura en una práctica familiar e hicieron de sus textos una producción indiferenciable de la masculina, pero la madre Laura está en otro punto. Tiene claro que es mujer. Tiene claro que sus relatos, cartas, crónicas y escritos diversos deben lograr algo para la obra de Dios, que no es su obra propia en el sentido de querer reconocimiento para sí misma. La escritura no es un medio para glorificar su subjetividad o proponerla como modelo de pensamiento y acción. Es un medio para obtener apoyo y dinero para su misión. Y por eso escribe con cautela porque no debe enojar a los sacerdotes, no debe dar lugar a ser mandada a callar y usa toda su malicia para escribir callando o escribir insinuando. Ni siquiera como superiora puede exigir, acaso puede sugerir que se dé un auxilio a las misiones. Sabe que es mujer, y conoce las tácticas del silencio, de los puntos suspensivos, del humor, de la ternura. Las razones son las razones de lo concreto. Y también usa las lágrimas porque sabe que alteran y que la debilidad exaspera al poderoso. La escritura está llena de dudas y preguntas por el alcance del poder de su cargo, aún para las cuestiones más pueriles:

Era la primera vez que salían de la región de Dabeiba a tierra civilizada y un temor asaltó a la superiora: ¿Sería lícito y corriente presentarse entre las gentes con el uniforme o hábito que llevaban? ¿No podría el excmo Sr. obispo ver en ello una usurpación? (Montoya, 1939, p. 131) 
En conclusión, con Aventura de Dabeiba estamos frente a un caso en el que resulta evidente que el autor es producido por el texto antes que al contrario. Pese a ello el texto posee las marcas del autor, las marcas de lo femenino, de lo afectivo donde lo religioso y espiritual de las tareas asumidas por el personaje que se despliega en el relato se plantean y se resuelven principalmente a través de elementos que estas marcas producen. Poco a poco en el presente escrito vamos explorando la manera en que las huellas dejadas en el relato de Laura Montoya por las marcas de su feminidad producen la trama verdadera, más allá de lo narrado, para dar cuenta del proceso de autoproducción en el relato biográfico, y como se proyecta esta escritura con una forma de humanismo alternativo, lo que realmente constituye el sentido de la indagación por lo femenino.

Por eso, al avanzar en el texto reconstruimos la historia de la lucha verdadera, la de la madre y sus monjas contra la autoridad de la iglesia. El drama debe ser recompuesto porque triunfar en su lucha implica renegar de sus sueños de ser monja amparada y legitimada por aquellos que no le reconocen mérito. Antes que una lucha épica, esta historia expresa una trágica experiencia de la vida, en la que se recompone una especie de drama donde no hay roles arquetípicos. Hay personajes, cada uno representándose a sí mismo desde una cierta distancia narrativa, porque a pesar de la informalidad del lenguaje, de su factura simple y hasta ingenua, Laura Montoya es consciente de que participa con unas ciertas cartas en una partida que muy difícilmente puede llegar a ganar. Si se somete a las reglas eclesiásticas pierden los indios, lo cual significa que ella pierde. Y si no se somete, pierde su comunidad de monjas que comparten su sueño misionero.

Datos provenientes de sus cartas misionales y de su autobiografía así como de diversos textos sobre su vida permiten creer que la madre soportó rechazo por parte de prelados carmelitas trapenses y de otras comunidades, a lo cual se opuso por supuesto, pero sin enfrentamiento. A través de tácticas femeninas también 
por supuesto, buscó la aceptación necesaria para mantener su pequeña comunidad a flote.

La superiora le seguía, deshaciéndose en atenciones y aunque él decía, con hiriente ironía que aunque tuvieran clausura, él no tenía por qué respetarla, puesto que las habitaciones de la casa de qué religiosas van a ser, ella sólo le contestaba. Sí, R. Padre, tiene razón; más él parecía no oírla. (Montoya, 1939, p. 192)

El texto está lleno de expresiones como éstas que a la larga revelan el drama de una superiora que no puede decir lo que piensa, que debe fingir acuerdo, que debe esconder sus éxitos y minimizarlos sólo por el hecho de ser mujer que ha tomado el oficio de los hombres: la dirección de un proyecto religioso y social. Las múltiples voces, las múltiples perspectivas, la crítica solapada, el lenguaje indirecto, el tono íntimo, así como los modos de expresar una conciencia de mujer hacen de esta memoria un relato con rasgos de antiepicidad. De manera textual Laura Montoya nos deja leer:

Esto me ha llevado a la convicción de que se necesita una nueva creación, de unas señoras monjas o hermanas cabras, es decir, de unas religiosas que llevadas del anhelo de salvar almas, se metan hasta las cuevas más remotas y sin pensar en nada, arranquen las almas al demonio para lo cual tendrán que asimilar su vida a la de sus infelices misionados. Pero cómo esta idea más bien parecía delirio de una mente desequilibrada que de una cabeza cuerda, a mí misma me asustaba y sufrí mucho; hasta llegué a pensar que me conducirían al manicomio, y me alegraba, porque me parecía que allí, en la suprema humillación, Dios escucharía mejor mis ruegos por los salvajes del mundo todo. (Montoya, 1939, p. 112)

Ciertamente, no es una obra de amor ni de erotismo que relata hechos del mundo doméstico. Es la historia de una mujer enfrentada a resolver asuntos públicos, pero sus criterios y sus decisiones provienen de un entendimiento del universo social interrelacionado a través de los afectos. La Misión es como una 
jurisdicción de frontera donde se encuentran mundos diferentes. Laura sabe que el afecto es mejor que la razón para facilitar la convivencia. Es claro que no intenta reducir los indios, pues al contrario, los quiere libres, aunque para ello necesite crear métodos inapropiados desde el punto de vista de la Iglesia y aunque por otro lado implique que ella y sus monjas tengan que renunciar al reconocimiento de sus nombres y el de la Misión. Destacamos el hecho de que este relato autobiográfico expone una lucha que ni la misma Laura Montoya es consciente de estar realizando. No hay tono de queja ni tono heroico porque su periplo personal no es lo que está por ser contado. A lo largo del texto, ella que es la conquistadora en su rol de misionera, resulta ser la conquistada por la vulnerabilidad e ingenuidad de las tribus que llegó a catequizar. Su voz que debería reproducir la voz de la iglesia, imita vocablos de paganos, como si su escritura se erigiera en el canal para convertir esos sonidos desconocidos en palabras audibles para la sociedad.

\subsection{La lógica "puesta en juego" en las prácticas discursivas femeninas}

Estamos acostumbrados a percibir claramente las voces de los personajes literarios. De hecho, las homogenizamos y de cierta manera las naturalizamos haciendo de las diferencias de registro algo circunstancial. Es como si voces diferentes en temas y sintaxis, compartieran la capacidad para expresar los pensamientos que el personaje alberga. Sin embargo, una de las mayores dificultades para lograr inferir el pensamiento o el sentimiento del personaje es la limitación de su voz, lo que se suele traducir como deficiencia en la construcción de los personajes o como escasa conciencia del autor sobre la situación narrativa. En la vida real también existen lenguajes homogéneos que mediante dispositivos culturales se van incrustando en la mentalidad de las personas para crear arquetipos sobre todo asunto posible de ser representado, pero existen otros que no pueden encontrar el camino al arquetipo puesto que permanecen mucho tiempo fuera del alcance de los condicionamientos culturales. Sucede así por varias razones. 
En primer lugar, por razones teóricas, puesto que las corrientes sociolingüísticas más actualizadas nos dicen que si no se pertenece a ciertos circuitos culturales, educativos, laborales o hasta religiosos -donde el lenguaje ocupa un lugar central- no es posible que el pensamiento discurra con los parámetros provenientes de esos ámbitos, por lo que parecerá ser pensamiento, ilógico, incoherente incompleto o impertinente. Como contrapartida, está el hecho de que, aunque es posible identificar con mucha facilidad el habla de ciertos grupos sociales, marginales, mujeres, población indígena o afrodescendiente, pandillas, y otros más, es difícil mimetizarla puesto que esos grupos no comparten todos los significados. Y en ello reside la dificultad para dar voz a los personajes y atribuir sus modalidades a algún elemento de identidad del grupo. Si se logra, se corre el riesgo de que los lectores juzguen que se trata de personajes inferiores, faltos de educación o de procesos formativos dentro de los estamentos culturales. Casi nunca asumen que los personajes, como usuarios de otros lenguajes, participan de esquemas de pensamiento alternativos.

Ciertamente, en el caso de personajes femeninos se sitúa este ámbito de reflexión. No podemos decir que sus voces preocupadas por el afecto, acostumbradas al poder de la gestualidad, inquietas por el contexto, confiadas en lo indicios, conectadas al rumbo de la conversación están en inferioridad estructural con respecto a la voz lógica que vehicula los significados a través de proposiciones lógicas apegadas al estándar semántico. No se trataría de un problema en relación con la falta de educación, información o conocimiento "culto" sobre el mundo, sino que se trataría más de un problema de perspectiva. Es verdad que históricamente las mujeres no han tenido el mismo acceso a los bienes culturales ni las mismas posibilidades de interacción con ellos ni a las instituciones que los agencian, pero cuando el acceso se produce ellas pueden comprender el universo cultural en sus fundamentos, lógicas de producción y consumo, perspectivas y posibilidades; sin embargo, existen factores que hacen de la mujer un ser humano 
cuyas preocupaciones y proyectos de vida se resisten -en alguna medida- a compartir el universo de creencias que fundamentan las prácticas de la cultura occidental.

La voz femenina, suena, en los textos de nuestro corpus, más consciente de las razones afectivas y emotivas de los comportamientos humanos; suena más preocupada por el contexto que por las formalidades textuales o discursivas; suena más conmovida por los seres vulnerables; suena más dispuesta a narrar los sucesos de la casa, a encontrar los detalles, a percibir el hilo que los conecta, a atesorar los recuerdos sentimentales de los que luego infiere información para entender su presente hecho de los mismos postulados culturales, pero además enriquecido por lo que permanece invisible a la cultura.

Heidegger (1998) plantea que, en estos casos de signo estético, es posible hablar en términos de combate. Un combate que se libra entre la tierra y el mundo entendiendo que el movimiento del mundo es producto de las visiones más recientes atravesadas por una columna cervical altamente racionalizada. La tierra, en cambio, está constituida por un gran número de sentidos olvidados que han sido conservados por voces marginadas que hablan desde prácticas consuetudinarias realizadas en nichos tradicionalmente subvalorados. La figura del combate, en este caso alude al hecho de que los significados subsistentes en el discurso femenino luchan por un lugar junto a los significados

Cuando decidimos realizar un acercamiento a Misiá señora, una novela de Alba Lucía Ángel con claro tono de denuncia, en que las protagonistas se llaman Mariana, una la abuela, otra la madre y finalmente la hija. Las tres han sufrido violencia y dominación por parte de los varones, sus esposos que se mueven de acuerdo con reglas patriarcales. Aunque la Mariana más joven tiene posibilidades de escapar de la tradición, comparte plenamente el destino de sus antepasadas a quienes se les niega la opción de construcción libre de su identidad. 
Al analizar el libro, nuestra primera intención fue la de comentar la estructura del texto, su armazón compleja y emprender el análisis de las múltiples voces que se iban fusionando para construir la narración. Sin embargo, pronto descubrimos que existían varios textos lúcidos que se habían ocupado de la interpretación de los elementos formales de la obra. Así que nos pareció una buena opción considerar la forma de la relación entre el texto y su autora, pero de nuevo desistimos. Habría rendido frutos si hubiese tenido otra narración similar que planteara diferencias y comparaciones pertinentes. Fue entonces cuando nos percatamos que el texto es susceptible de ser analizado enfocándose en el mundo postulado en la ficción: la construcción de la imagen femenina en un medio androcéntrico, pues Misia señora revela un orden invisible que se crea constantemente en el seno del orden visible patriarcal.

Un mundo desigual relatado con un lenguaje poético y críptico que sobre la aparente ausencia de voz, ausencia de memoria, o la ausencia de algo que pueda llamarse identidad femenina, deja entrever un acumulado de prácticas lingüísticas y tácticas que permiten el reconocimiento en la medida en que se constituye en un orden alternativo que disloca el orden oficial. Penetrar en la alternativa propuesta y reconocer sus lógicas y opciones se convirtió en el propósito de realización de un trabajo sobre literatura y feminidad, entendiendo por femenino un impulso hacia la creación de un proyecto humanista que contenga no sólo los patrones racionales, sino también las consideraciones sensibles en la fabricación del mapa del mundo o en las consideraciones sobre los procedimientos legítimos para la toma de decisiones y el establecimiento de la juridicidad.

A través de las voces de las Mariana, la abuela, la madre y la hija, y los ecos de sus antecesoras y futuras proyecciones, se percibe la dificultad para reconocer un saber de la madre que pueda considerarse patrimonio, que pudiera constituirse en un sistema de herencia espiritual -con las características habituales 
que un sistema posee- objetividad, coherencia, posibilidad de totalización- para entregar como enseñanza a las hijas. Ninguna de las mujeres de la novela puede construir un discurso propio, con los referentes naturales de una existencia cabalmente comprendida, pues para lograrlo deberían poder contar con un conjunto de condiciones para penetrar el significado que por ser mujeres se les niega. La tarea, en este análisis, será la de mirar las condiciones del discurso femenino dentro de la situación de dominación en el orden patriarcal, así como la forma misma del habla y lo que ese hablar pudiera llegar a referir.

Para lograrlo seguimos a Michel de Certeau, cuando en su libro La invención de lo cotidiano (2000), examina las prácticas culturales involucradas en las relaciones de dominación. Las trayectorias definidas en sus análisis etnometodológicos permiten usar los significados culturales para situarse en cualquier escenario discursivo y reconstruir algunas características de los hablantes, en este caso, para descifrar el comportamiento discursivo en relación con el género de los personajes de Misia señora, que pese a todas las apariencias no se limita a representar la pasividad de las mujeres sino que define un lugar alterno en el que se despliegan tácticas de resistencia hacia los roles y los lenguajes impuestos desde un cierto modo como ejercicio del poder.

Para lograr avanzar en este modo de análisis es necesario partir de algunos elementos que al sistematizarse pueden revelar la lógica oculta detrás de la poética del texto:

Existe un sistema organizado de dominación -el sistema patriarcal- que instaura modelos de representación en los que el reino de la vida privada resulta ser el escenario propio donde la mujer desenvuelve sus acciones y lenguajes. Lo privado y los personajes que lo constituyen se ponen deliberadamente como mundo inferior mediante estrategias diversas que incluyen declaraciones directas de los patriarcas y el desconocimiento sistemático de lo que constituye el universo femenino. 
Porque está escrito desde siempre. Porque abatir esa estructura sería el trastorno de la norma, la subversión, el caos, el revuelo. Cuando mi padre dijo, porque mi abuelo dijo, porque su padre dijo, porque su abuelo había ordenado, ya el destino era así: infracto, terminante. (Ángel,1982, p. 44)

Por otro lado, existe la posibilidad de un juego para ensayar órdenes diferentes en el seno del sistema que, usando las mismas construcciones impuestas, mediante diversas formas de escamoteo, crea accesos a la pluralidad y a las expresiones alternativas del deseo y la voluntad. El juego se construye mediante tácticas -las armas del débil- ejercidas al margen del sistema.

Tal como indica De Certeau llamaremos estrategias a las artes del dominador para imponer sus reglas de juego al dominado y tácticas a las armas del débil para resistir la dominación.

El arte de valerse de esas tácticas de escamoteo es antiguo. Se transmite de madre a hija de manera no explícita, pero conforma un repertorio de esquemas disponibles que van distinguiendo como femenino. En casos extremos el suicidio y la locura hacen parte de este repertorio. La mayoría de esas actuaciones y representaciones son furtivas y clandestinas como corresponde a los órdenes invisibles en los que no hay producción cabal de lo propio, y en los que es difícil reconocer una lógica de producción discursiva para ayudarse a comprender la existencia.

Las tácticas del débil descubren un juego en el que las representaciones y los modelos normales de lo patriarcal se subvierten, mediante usos no ordinarios de esas mismas representaciones y modelos. Deben referirse a subversiones de aquello que sostiene las formas de representación: una cierta concepción del espacio como espacio alternativo al espacio inaugurado desde las actuaciones de poder. Deben referir una concepción del tiempo diferente del tiempo continuo como previsión que controla las irrupciones del azar; y deben referir 
una cierta concepción del yo y una cierta concepción del otro. Espacio, tiempo, ideas acerca del yo y la alteridad son nociones que permiten crear un modelo de mundo suficientemente coherente para moverse dentro de él e interpretar lo que sucede, aunque el resultado no sea el universo familiar patriarcal.

En lo que respecta a este último punto, para el caso de Misia señora vemos que estas condiciones se traducen en varias de las siguientes posibilidades:

- La instauración de un hablante y de un interlocutor. Ambos ficticios y plurales, que sostienen la comunicación de lo femenino en el escenario de dominación.

- La creación de una temporalidad presente, extraña tanto a la memoria como a la previsión y que se revela en la sensación de estar en el umbral entre la vida y la muerte o ante la amenaza constante de locura.

- La instauración del lugar propio en el espacio inexistente del cuerpo que se erige en centro y convergencia alucinada de sensaciones imaginarias, o en el abismo del espejo; ambos lugares opuestos al lugar reglamentario -que como dice De Certeau- es aquél dentro del cual se organiza la dominación, se acumulan las ventajas y se administran las relaciones sociales. En esta novela, el cuerpo dice a Mariana (abuela, madre o hija) que es violada permanentemente de muchas maneras. "Ella con el sexo agarrotado, con un dolor constante y el montándola, brioso, apretujándola, las manos duras debajo de las caderas." (Ángel, 1982, p. 138)

El punto de partida en la novela es el fracaso del discurso femenino en su intento de crear una imagen propia y una voz, mientras el sistema de representación patriarcal esté vigente. El epígrafe inicial del texto lo plantea “¿Dónde reinventar el gesto y la palabra, si todo está invadido por los significados antiguos, y nosotras mismas, hasta los huesos, hasta el fondo de la médula...?". Al construir este acceso a su universo de ficción la 
autora permite no sólo ver los mecanismos mediante los cuales se niega la construcción de lo femenino, sino vislumbrar la existencia de alternativas empleadas por la mujer para mantenerse al margen, pero sobre todo abre una puerta a la creación de un sistema de estrategias femeninas que se oponen abiertamente al orden vigente. Personajes clave como Yasmina, Anais, la Mariana que administraba su herencia, y la Mariana que quería hacerse escritora y abandonar la casa asumen -fundadas en un sistema autónomo de representación- un rol de oposición abierta a los reglamentos y disposiciones.

Señalemos ahora algunas de las estrategias implementadas por los personajes masculinos de la novela para crear la situación de dominación e instaurar sus propias condiciones de representación

- Primera estrategia: Declaraciones directas, como:

¡Mariana!,....estás histérica

O esta de la página 137: ¡Mariana!,....tu eres frígida

¿Una mujer pensante..? Cuando meen las gallinas. O sea, los huevos del gallo (p.258)

- Segunda estrategia: Comentarios indirectos.

...cuando grandes quieren plantar su verga, donde puedan, porque es un signo de poder, y una mujer si está debajo de ellos quiere decir que está en su sitio.

- Tercera estrategia: Declaraciones de personajes de la historia del pensamiento, como en el epígrafe de la tercera parte:

Cuando vayas con una mujer no te olvides el látigo (Nietzsche) (p. 227).

La cabeza de la mujer es el hombre (San Pablo) (p. 227).

- Cuarta estrategia: Imposición de reglamentos y modelos de conducta. En el texto se encuentran varias referencias a la Virgen María como modelo para las niñas; el silencio y la obediencia como formas adecuadas para la mujer casada, y la culpa como 
el mecanismo de autocontrol para quien se atreve a romper las reglas.

- Quinta estrategia: La violación

La del sirviente Atalvas a la niña Mariana.

La del marido a su joven esposa Mariana, antepasada de la anterior.

- Sexta estrategia: La imposición de horarios y tareas; el otorgamiento de castigos y dones, la dispensa de burlas son estrategias de dominación que entre muchas se despliegan en la novela y reproducen la situación de poder mediante una educación en la que el varón aprende de sus mayores los modos de representación adecuados para su ejercicio.

En medio de las situaciones creadas por las estrategias de dominación se van estableciendo prácticas subversivas, tácticas de resistencia, entre las que resalta la del sigilo. Llamamos sigilo a esa práctica comunicativa de sustracción del yo, en la que la mujer delante de los varones tiende a replegarse a ocultar o callar, así que finge que no sabe, finge que no desea, finge que no ve. Hay una invención del yo que se pone deliberadamente en la escena de la interacción social como respuesta a la estrategia masculina que condena a la mujer a no decir, a no pensar, a no saber. Esa es justamente la situación de quien se enfrenta al mundo desde la posición de subordinación que define trayectos vitales antiépicos, en los que no es posible erigirse como sujeto ejemplar de la comunidad o como voz autorizada para encarnar los valores propios de la colectividad. En la obra de Alba Lucía Ángel podemos leer estas manifestaciones de dominación:

Yo me levanto ufana, dispongo en la cocina, ordeno aquí o allá, muy mirla, rozagante, por más que Arlén decida que este bistec no está cocido, o que por qué tanta demora, pues me entra por aquí y me sale por allá, porque resuelvo estacionarme, sin alterar los ritmos de mi cuerpo, que se distiende en ondas tardas: apartadas del gris y el atropello. (Ángel, 1982, p. 154) 
Aquí aparece una voz femenina que declara para el lector su práctica del sigilo, pero en general, las Mariana protagonistas y víctimas de la dominación, se escapan hacia regiones de inconsciencia mediante cantos y repeticiones de palabras que a manera de conjuro permiten la salida a una dimensión más libre de la existencia.

De las tácticas del sigilo hacen parte la negación de los sentimientos y de los deseos como cuando Mariana niega delante del padre o delante del cura que se ha besado con alguien, que come mocos, o que alguien la ha tocado. Pero de tanto negarse a sí misma Mariana termina por no reconocerse, con lo cual avanza en un camino de desconocimiento de estabilidades de cualquier tipo, camino comenzado cuando todavía era niña y en una comprensión temprana de su destino subversivo le vende el alma al diablo. El hecho permite que aflore un yo verdadero con sentimientos y modos de valoración propios. Ese yo no necesita fingir, pero se opera una inversión en la relación con el otro, porque, paradójicamente, cuando aparece el yo auténtico, en cuerpo y voz, se precisa la invención del otro (o mejor, tal vez decir, de las otras). Son sus antepasadas muertas, su propia sombra, su imagen en el espejo, las mujeres perdidas en la memoria de sus hijos, además del demonio mismo.

Visto así, se hace imposible cualquier comunicación, pues mientras Mariana, la protagonista está en presencia de hombres de carne y hueso el yo femenino se retrae. Sólo hay un cuerpo apocado que se traga las palabras, reprime la voz, se aleja gateando o redunda en nombres y expresiones, como si repitiera cantos o encantamientos donde no corresponde, o como si su única capacidad fuera la de multiplicar inútilmente los detalles, confundiendo lo importante con lo banal. Por otro lado, mientras el yo está, el interlocutor son sólo otras mujeres tan mudas y apagadas como ella. De ahí, la costumbre de mirar el rostro de la muerte; la táctica de pensar en otra cosa para no sentir lo inmediato, como aconseja la madre, de no resistir la dominación abiertamente, pero negándose a la entrega. 
Sin embargo, esa praxisyesastácticas no son tan generalescomo debieran. En el interior del sistema se alzan voces que representan la feminidad al margen de las imposiciones. La reubicación de la culpa, la banalización del adulterio, la desacralización de la maternidad, la revaloración de la sexualidad y la afirmación de la autonomía conforman un conjunto de estrategias de carácter antiépico, capaces de hacer oposición a la reglamentación vigente para legislar sobre lo que puede experimentarse y vivirse. Cada generación de Marianas se acompaña por una mujer, Yasmina, Anaís, Idania, misiás señoras, que saben hacerse valer por sí mismas, como la primera misiá señora, Mariana de Ontaneda, que las impulsa al reconocimiento, pero que pagan el precio de quedar por fuera del sistema de lo que ya tiene nombre y significado.

Las mujeres, a diferencia de los varones que tienen modelo oficial en la cultura para construirse, no tienen otro modo de configurar su identidad más allá del reconocimiento en otras mujeres tan concretas como ella: la madre, la abuela, la amiga. $\mathrm{Y}$ es que los arquetipos del repertorio cultural son casi todos masculinos: el héroe, el sacerdote, la figura de autoridad, el guerrero, el sabio, y existen como parte de los modelos que cualquier hombre puede adoptar más allá de los lazos de familia o de comunidad. Normalmente los modelos femeninos se reducen a la santa, la prostituta, la hechicera, ninguno que pueda asumirse como un emprendimiento de identidad, y ni siquiera, como asunto para una vocación real que permita ir a la pregunta por el proyecto propio de vida, por el valor de la elección de modelo como un acto de libertad individual. Madre, enfermera, maestra o secretaria son roles corrientes para la mujer, pero apuntan a unas mismas cualidades que deben ser compartidas por todas. Las del cuidado y la abnegación, como una negación del sí mismo femenino al servicio del género humano, que termina por opacar todo impulso individual hacia la autorrealización.

De algún modo, las novelas escritas por mujeres dejan ver, en su mayoría, mujeres asfixiadas en sus roles, fracasadas en la 
consecución de algún fin personal, donde la salida al conflicto llega por casualidad, de la mano de un agente externo o por la renuncia a sus intereses y a cambio de ello, el enamoramiento, el amor a los hijos, afectos que terminan por devolver el sentido de la vida. $\mathrm{O}$ no hay salida. Las autoras escriben sobre mujeres que no tienen salida, no sobre heroínas. Se convierten en locas, en monstruos incapaces de afección o de ternura. O inventan un modo de vivir con las consignas propias de las vidas masculinas como en $L o$ que el viento se llevó, de Margaret Mitchell o se convierten en verdugos, como en La perra, de Pilar Quintana o viven de manera inconsciente, alienadas por la rutina de los trabajos encomendados como en El oído miope, de Adriana Villegas. O quizás comete una forma del amor pecaminosa, incestuosa, como en La azotea de Fernanda Trías. Las protagonistas de estas ficciones no logran ser felices, están llenas de frustración y amargura por las tensiones que se producen entre lo que la gente espera de ellas y lo que ellas pueden llegar a ser. Scarlett O'Hara en Lo que el viento se llevó no es capaz de ser una buena madre ni una buena mujer; tampoco la negra, protagonista de La perra puede ser madre y también fracasa en construirse con los atributos de la mujer tierna incapaz de matar una mosca, o como Cristina Mejía, la protagonista de El oído miope que se aliena de su condición humana, pues vive la rutina más miserable que un trabajador puede vivir. Clara, la protagonista de La azotea de Fernanda Trías ama a su padre y es hermana de su hija, pero su afecto crea una trampa para todos; los condena a ellos y a sí misma a vivir prisioneros en una jaula común.

\subsection{Los mecanismos de la concienciación de los personajes femeninos}

Para analizar la categoría de concienciación como forma de escritura antiépica en la novela "Todos se van" escrita por la cubana Wendy Guerra (2006), recurrimos a la obra de la crítica literaria Biruté Ciplijauskaité: “La novela femenina contemporánea (1970-1985): Hacia una tipología de la narración en primera 
persona"(1988), quien en su análisis sobre las particularidades narrativas de las mujeres escritoras acude a elementos comunes a muchas de ellas en la novela de formación, a la que también denomina novela de concienciación. Para explicar este concepto acude a Elizabeth Abel:

Ha reunido varios ensayos acerca de lo que ella ve como manifestación más característica en la escritura femenina de hoy: la novela de formación (Bildungsroman), que ella propone denominar "novela del despertar" para subrayar las diferencias entre las estrategias narrativas masculinas y femeninas". La palabra española concienciación transmite con más exactitud este nuevo viraje. Se trata de una novela de formación, pero sobre todo del desarrollo de la conciencia. (Ciplijauskaité, 1988. p.20).

La autora se inclina a pensar que las mujeres construyen un "yo" anclado a la memoria y a las experiencias íntimas de la niñez, lo que explica que prefieran géneros como la novela de concienciación y como recurso de narración acuden al diario íntimo o la autobiografía, como estrategias que se dirigen al mundo de la subjetividad, lo que se constituye en un recurso de la narradora, como reacción al universo masculino literario. Estas observaciones serán útiles para comprender mejor el universo de la escritura femenina en la que el relato se desvincula de la obligación de dar un nombre formal y legítimo al universo que describe, pues la escritora prefiere las marcas de lo concreto y lo distinto, lo que está atravesado por la mirada personal. En sus ficciones, las escritoras ponen en evidencia la situación actual de las mujeres, lo que significa que cuando las autoras comienzan a revelarse como creadoras importantes en la escena literaria, se preocupan por hablar de la situación femenina, de los problemas ligados al género, de la conquista de sus derechos y en la solicitud de respeto a sus formas de ver su mundo y de sentir.

Sin embargo, sus búsquedas, más que afirmar una identidad femenina esencialista, se dirigen a explicar el lado perturbador de su mundo íntimo, propósito mucho más evidente en la 
novela de concienciación en la que la narradora se ocupa de las relaciones familiares, los cambios operados en el cuerpo y la mente, mientras la niña va sufriendo su transformación en mujer, y va develando lo difícil de las relaciones que se pueden presentar entre el deseo y el sexo. Las mujeres necesitan ser escuchadas, una voz con la que puedan exclamar lo que sienten. Y es a través de los textos literarios que las mujeres desnudan sus debilidades, miedos y sentimientos y se apropian de sus espacios y sus roles. Se enfocan en procesos de autoconciencia, en una búsqueda por reconocerse y enriquecer nuevos puntos de vista sobre el alcance e interpretación de las novelas, dándole a la escritura la capacidad de enunciar su realidad. En primer lugar, porque la producción narrativa se sitúa como medio de constitución de una nueva identidad o una identidad emergente $y$, en segundo lugar, porque la literatura establece tal identidad como femenina en el sentido de validarse en un plano diferente y nunca inferior a las valoraciones masculinas. Ciplijauskaité (1988) lo expone así:

Lo que les interesa a las autoras contemporáneas no es sólo contar o contarse, es hablar concretamente como mujeres, analizándose, planteando preguntas y descubriendo aspectos desconocidos e inexpresados. Es un constante esfuerzo de concienciación que necesita un lenguaje adecuado (p.17).

Este viraje permite que la literatura adquiera otro estatus porque se enriquece de manera diferente, tiene otros alcances, otros modos de expresión, otras preocupaciones y comprensiones de determinados aspectos del mundo, que sirven como dispositivos de participación o visibilización de la conformación misma de la mujer como creadora literaria, donde se desplazan los modos de existencia de los referentes establecidos por los que podríamos llamar el discurso oficial masculino. Podemos pensar que la literatura femenina se desliga de la literatura masculina por cuanto su lenguaje construye referentes distintos para crear un universo femenino diferente, en el que existen otras lógicas y formas de aprehensión, donde se develan sensibilidades 
particulares. (Ciplijauskaité (1988) expone: "Para transmitir modos de percepción femenina se renuncia al lenguaje y a las normas de composición forjados por los hombres, se introduce un léxico diferente" (p.17), dejando visible que las mujeres utilizan otras formas de narrar y comunicarse. Por eso, se indaga sobre las manifestaciones del género literario femenino; una de las tareas es esclarecer que existen diferencias entre la narración masculina y la femenina, de modo que sea posible explicar que pertenecen a otras formas narrativas literarias y lo hacemos a través del análisis de la novela Todos se van, de la escritora cubana Wendy Guerra (2006), bajo las siguientes categorías analíticas propuestas por Ciplijauskaité (1988).

La novela de concienciación abarca muchos aspectos de la vida femenina. Sería difícil ponerle límites exactos. Para establecer cierto orden en la discusión proponemos considerar las modalidades siguientes: concienciación por medio de la memoria; el despertar de la conciencia en la niña, que pone más énfasis en los años juveniles; el pleno darse cuenta de lo que es ser mujer; la maduración como ser social y político; el llegar a afirmarse como escritora. Dentro de éstas, hay otros aspectos que llaman la atención, como la relación entre madre (o padre) e hija. [...] En todas, la memoria tiene un papel importante y configura el discurso. Sólo la formación de la mujer como escritora no implica siempre este recurso. (pp.37-38)

Todas estas categorías las encontramos, en Todos se van, donde se privilegian ciertas formas de escritura antiépica centradas en descubrir un grado de exposición de Nieve Guerra, la protagonista, quien por medio de un discurso en primera persona pone de manifiesto sus experiencias de formación como un registro íntimo, en un diario que no busca ser libro público ni ejemplarizante, sino el testimonio de su experiencia particular. 


\section{Concienciación por medio de la memoria}

Esta concienciación se construye por medio de un proceso de evocación de recuerdos, que coincide con la búsqueda personal de la identidad. Este recurso que se hace presente en la novela de concienciación le permite a la protagonista transitar hasta llegar a la adolescencia. En Ciplijauskaité (1988) podemos leer: "Numerosas novelas contemporáneas femeninas presentan el paso de niña a mujer, que frecuentemente es marcado por la "adquisición del recuerdo" un empezar a ver el pasado -los días de la inocenciacon ojos distintos" (p.38). La reconstrucción a través del recuerdo ayuda a desentrañar el pasado y a dejar huella en el presente, haciendo posible la continuidad histórica por medio de la voz enunciativa quien nos relata su vida en una narración en primera persona y devela sus modos de ser y de pensar, enmarcados por la intimidad. "El uso del "yo" permite gran variedad de enfoques: concentrarse en transmitir una visión inmediata de lo que está ocurriendo - intención que predomina en la novela actual - o crear una relación retrospectiva, que implica superposición temporal y acumulación intensificada del significado" (p.18).

En Nieve Guerra podemos escuchar su voz; que tiene el interés adicional de que todos los acontecimientos cubanos queden registrados a través de una experiencia personal, considerando que Cuba en la década de los 70 fue identificada por esa división social entre aquellos que salen de la isla o los que deciden quedarse y es con esta narración donde surge la toma de conciencia. Nieve se centra en el "yo" como un universo en el que descubre el encanto de la introspección como un modo de evocar los recuerdos de su infancia, referidos a acontecimientos externos y a reflexiones políticas. La historia pasa a ser retrospectiva personal porque Nieve relata sus propias vivencias, como aquellas cuando la mayoría de sus amigos eventualmente salían del país:

Cada vez que cierro una puerta me parece que no voy a ver más a esas personas que están donde yo estaba. Las miro fijo para que 
no se me olviden nunca. Es un momento pequeño, es un instante en que me llevo todo lo que hay allí con los ojos. Le puse a ese momento "los nuncajamases", porque sé que nunca jamás volveré aquí y allá y a tantos lugares en los que he vivido. (Guerra, 2006, pp. 93-94).

Los "nuncajamases" le permiten a Nieve dar cuenta de su capacidad de guardar en la memoria las imágenes de pérdida y su diario le permite que estos momentos perduren. En Todos se van el querer irse se dibuja como la meta de todo un pueblo y para los que no pueden salir la permanencia se constituye en cautiverio y se torna insoportable vivir en una isla inhabitada por el ambiente angustioso de la carencia y la opresión. El paratexto, en las primeras páginas de la novela, de Charles Baudelaire: "La patria es la infancia", nos permite a través de los primeros años de Nieve, llenos de hechos infortunados, reconocer a Cuba como una isla fragmentada, incierta.

\section{El despertar de la conciencia en la niña}

En las novelas de concienciación, el personaje principal recorre su niñez sintiendo que ésta es incompleta. Por eso, conscientemente organiza su experiencia de iniciación con nuevos conocimientos para demostrar que la vida tiene significado, como un punto de inflexión basado en la complejidad y versatilidad del desarrollo de su personalidad. Lo que finalmente la lleva al autoconocimiento, a encontrar su lugar a través de sus andanzas hasta su maduración, el cual le permite evaluar su crecimiento y profundizar en la reflexión sobre su existencia. En última instancia, todo ello forma su personalidad, porque este personaje está cambiando constantemente por la influencia de factores psicológicos, fisiológicos, sociales, culturales y políticos. Ciplijauskaité (1988) nos ilustra: "La novela moderna se destaca por su orientación hacia la indagación. No se contenta con narrar o exponer quiere descubrir las motivaciones interiores de toda actividad individual, así como los acontecimientos políticos" (p.34). 
El proceso de concienciación de la niña va ligado a las decisiones que toma en el transitar por su mundo y cumple un papel importante en el desarrollo de su carácter y personalidad, porque, desde un ejercicio intelectual - afectivo, le aporta a su crecimiento y a adquirir madurez mental. Con el despertar de la conciencia, la autora propone:

La novela de formación que se concentra en las experiencias de una niña antes de llegar a ser mujer, aunque no tan abundante como la que presenta el proceso de conversión en mujer, se acerca a ellas con enfoques variados. Se podría dividir básicamente en infancia y adolescencia vistas positiva o negativamente. (Ciplijauskaité,1988 p.42)

En este proceso podemos ver a Nieve, una niña concebida como hija única, que se está enfrentando a las tensiones con el mundo interior y el exterior; se encuentra con desacuerdos debidos, generalmente, a su inexperiencia; cae en el descontento en la escogencia de sus amigos o acata de alguna manera las exigencias de sus padres, de su tiempo y de su ambiente. Ciplijauskaité expresa: "La experiencia de la niña se desarrolla en el plano humano" ( $p$. 44). La protagonista experimenta un proceso de maduración largo, arduo y gradual, con la presencia de escenas o vivencias repetidas en la relación con sus progenitores. Ella debe encajar en un molde que le han presentado como norma, lo que indica que estas experiencias pueden ser frustrantes, ya que pueden sugerir opciones que no contempla o con las cuales no está de acuerdo. Por lo tanto, en su trasegar va asumiendo la realidad como suya y, junto con ella, el deseo de ser independiente. Dentro de la escritura antiépica, los discursos de tipo patriarcal no parecen tener mucha acogida pues la objetividad como característica de la racionalidad que les es propia, estorba el libre flujo de la conciencia de quién enuncia un discurso ligado a la sensibilidad, a los sentidos, a la memoria corporal y la emoción.

Todos se van consta de 264 páginas repartidas en dos capítulos. El primero se abre con Diario de infancia y el segundo con Diario 
de adolescencia, los cuales obedecen a dos tiempos narrativos diferenciados, donde la escritora utiliza el diario íntimo para contar una microhistoria dejando leer las experiencias de Nieve, quien con una voz individual página tras página deja entrever sus pensamientos y cada uno de los momentos vividos. Este recurso estilístico permite darle vida a la escritura. García- Berrío y Huerta- Calvo aseguran con respecto al diario:

Cuando el diario pasa a ser una técnica de la narración ficcional, una de las formas de la novela en primera persona -junto con las memorias y la novela epistolar, sus propiedades -fragmentariedad, incoherencia, etc.- adquieren un status semiótico distinto: se convierten en elementos y medios de expresión en el seno de la estructura de una obra. (1992, p. 119)

El diario como estrategia narrativa tiene el efecto de considerar que los eventos realmente sucedieron o que son verdades a medias, generando expectativas en el lector, pues representan una verdad más allá de los hechos. En los diarios, las implicaciones plausibles de la conducta humana pueden interpretarse de manera controlada, pues la inclinación notable de la redacción en primera persona permite encontrar la propia expresión femenina, al reflejar el carácter reservado de este universo construido desde la feminidad.

En la novela, Wendy Guerra tiene la intención de conducir al lector a las confrontaciones de Nieve en su infancia y en su adolescencia, como una niña que no toma decisiones, que se deja gobernar y una adolescente más realista en medio de un mundo hostil. La apropiación de experiencias concretas y la relación de Nieve con su entorno desencadenan el proceso de evolución o formación; Guerra despliega ciertas estrategias narrativas para que se desarrollen paralelamente. La evolución de Nieve se presenta clara consigo misma. Toma su lugar optando por no salir de su país; y esta decisión marcará su pasado y su presente. Nieve da inicio a su narración con los problemas de sus padres: "Mis padres ya no están, se han ido poco a poco. Sin embargo, en esta orfandad 
se imponen con un peso mayor al de sus antiguas ordenanzas" (p.11). Cada experiencia vivida le ayudará a Nieve a cimentar su camino y a cortar lazos de sangre; como lectores, somos testigos de su evolución a través de sus desplazamientos narrativos.

Con Diario de Infancia seguimos a Nieve desde Cienfuegos hasta La Habana. Inicialmente habita en Cienfuegos con su madre y Fausto, su padrastro, un sueco que casi siempre está desnudo, que no entiende bien el español y quien se convierte en su cómplice, al poco tiempo su madre se ve obligada a irse para Angola: "Estoy en huelga de Diario, porque se llevaron a mi madre a la guerra de Angola. Esta página está en blanco en su honor" (p.19). Esta página sin letras que leer es una muestra del miedo a la pérdida, es la revelación de que las despedidas le duelen, que guarda sus recuerdos, pero no los plasma en su diario. Por su parte, su papá con quien la une una incapacidad de comunicación, acusará a su madre y a su compañero por conducta inmoral y esto le permite conseguir la custodia de la pequeña. "Ahora no podemos cambiar eso, ya hay que ir al juicio y será mañana.... mañana dejaré de ver a mi madre, lo sé. Pero hoy dormiré con ella toda la noche." (p.33).

Así comienzan los problemas para Nieve al no tomar decisiones y no responderle al juez la pregunta con quién quiere vivir; con su madre o con su padre: "Yo sé que debí haber dicho que quería quedarme con ella. El miedo a mi padre no me deja nunca hablar. Cuando estoy sola, me propongo hacerlo, pero con él delante nunca lo cumplo" (p. 35) y termina viviendo con él. Ciplijauskaité (1988) al respecto plantea: "El proceso de concienciación consiste no pocas veces en este darse cuenta al encontrarse delante de una elección difícil" (p. 46). Nieve termina al lado de su papá, quien le impone normas, así estas vayan en contra de la verdad, por lo que termina siendo silenciada, como muchas otras protagonistas de novelas escritas por mujeres. Esta situación deja en evidencia los desencuentros con su progenitor y desencadenan en conflictos familiares que construyen una imagen autoritaria a través de órdenes recurrentes: 
Primero, que no podía contestar nada que me preguntaran sobre él. Segundo, que cuando no fuera a la escuela tenía que decir que estaba enferma. Y, tercero, que no podía hablar con nadie de si comía o no comía. Ahora estaba castigada y por contarle a la maestra me quedé sin comer hoy otra vez. Mi padre sacó la botella del escaparate, rellenó la de su pantalón y me encerró en la casa. Todo lo dijo bajito y con mucha rabia. Se fue. Tampoco hay luz. No sé cómo puedo aguantar la oscuridad. Me dan ganas de llorar, pero no quiero. (Guerra, 2006, p. 49)

La exposición de los detalles narrativos que podemos identificar a través de las conversaciones con los personajes que rodean a Nieve, nos permite darnos cuenta de las experiencias de abuso de su padre y cómo finalmente se libra de éste, terminando en un centro de rehabilitación para menores, que además es un internado para huérfanos; viviendo la ausencia de sus progenitores y en un arrebato de desesperación se confiesa: "Prefiero estar aquí, sé que me van a respetar. Los niños son peores que los adultos porque no les tienen miedo a las responsabilidades. Pero si puedo con los adultos puedo con los niños". (p. 87); así se expresa Nieve con tan solo nueve años, como si fuera una adulta que busca respuestas, donde se refleja una indagación sobre su existencia.

Nieve sigue registrando en su diario los hechos de su pasado recientey revela sus estados deánimo, sus emociones y su evolución, a través de la exposición de su drama interior, generando espacios de significación a través de una presencia permanente en la que se ponen de manifiesto los conflictos sociales, los comportamientos de sus amigos y el abandono de sus padres. Nieve siente miedo. El hecho de sentirse desprotegida ante las agresiones de su propio papá, la inseguridad que siente en el centro de rehabilitación, las constantes separaciones de los que ama logran que la sensación de miedo crezca cada día, porque su universo infantil no comprende las circunstancias políticas que le imponen. Su madre un cierto día le dice: "En Cuba la política está en lo que comes, en donde vives, en lo que tienes y hasta en lo que no tienes" (p.187). Guerra insiste en construir una esfera familiar que refleje la desintegración 
familiar y la nacional, pero no juzga a Nieve, recurre a la queja, simplemente ella sabe que se trata de sobrevivir porque no tiene más opciones y porque desconoce otros mundos.

La autora, con el fin de textualizar la etapa más problemática de Nieve, propone otra focalización narrativa y se detiene en los momentos vividos en la institución donde se educa. Allí organizan actos de rechazo en contra de aquellos que quieren abandonar la isla, obligando a los estudiantes a ser testigos de las torturas y humillaciones; situaciones que causan horror a madre e hija. Es un viaje al interior, nutrido de pensamientos, sentimientos, ira y sufrimiento de una niña que espera crecer. La novelista propone un lenguaje de la niñez con el que Nieve va narrando sus experiencias vividas al lado de su madre, su paso por la escuela, las relaciones con sus amigos y sus miedos de infancia.

No sé qué voy a hacer, mami me prohibió ir a los actos de repudio, esos que les hacen a los que se van del país. Yo los he visto cuando voy por el Vedado y la gente tira huevos, tomates y piedras a las casas de los que se van. Una muchachita de la escuela que se llama Yazanam les puso a esos actos "los-que-se-vayan". A veces hasta arrastran por el suelo a los que se van. Me da un miedo que se le ocurra irse a alguien que uno conozca. Están igual que mi padre, golpes y golpes sin dejar que uno pueda ir a donde quiera. (Guerra, 2006, p. 112)

Este cúmulo de experiencias permite que Nieve vaya forjando su madurez a través de la pérdida y el dolor. En Diario de infancia, la escritora deja ver los rasgos femeninos de Nieve, producto del condicionamiento social, conectado con sus capacidades afectivas y sus modos de proceder únicos desde el rol de género que socialmente ha construido. Por eso, aunque esté privada de oportunidades termina siendo sensible e indulgente consigo misma y con aquellos a quienes teme:

Mi papá se metió en la embajada del Perú para irse del país. Allá en Miami están mis abuelos esperándolo. Mi papá salió en el primer 
grupo, así que ya debe de estar en camino. No me importa. Se lo dije a mi mami y ella se quedó muda. Para mí es mejor. Ya no me va a pegar más y no tenemos que esperar el permiso para irnos. (Guerra, 2006, p.117)

Nieve deja visibilizar su propia indulgencia pues ha sabido curarse a pesar de sus inquietudes y miedos; y pone de manifiesto la razón sobre las emociones y dejará de lado sus comportamientos de sumisión. Al menos consigue sonreír a pesar de sus heridas, consigue vivir al margen de los cuestionamientos. En su hacerse adolescente va alejándose de los modelamientos femeninos y parece modelarse según los dictados patriarcales.

\section{El pleno darse cuenta de lo que significa ser mujer}

En Diario de adolescencia, Nieve ha crecido y su lenguaje es más elaborado. En su estrenada juventud es más consciente de la realidad política de su país. Ciplijauskaité (1988) define esta nueva etapa de esta manera: "La novela trata de transmitir no sólo el crecer de la niña como persona consciente, sino también el de su capacidad lingüística para expresar esta conciencia..." (p.43). Es a través del lenguaje verbal que Nieve nos deja conocer su realidad. Vive con su madre y su padrastro, Leandro, y asiste a un instituto de artes. Podemos leer en esta segunda parte de su diario, la permanencia en un reformatorio y en la Escuela de Arte, sus estados de soledad y sus experiencias de amor:

Es la guerra fría, la guerra del silencio adolescente. Si no eres parte del grupo, no tienes novio; si no eres popular entre ellos, te rechazan, se burlan, te conviertes en algo con lo que no cuentas. Les molestas, les estorbas, no te comprenden y por eso se desquitan. No puedes soportar que tengas tu propio mundo y yo tampoco soporto que me rechacen. (Guerra, 2006, p.124)

Nieve ya es una adolescente mirando hacia atrás y recordando todos los eventos que la llevaron a la pérdida de la ingenuidad. Va transitando el camino de la edad adulta y toma decisiones en una búsqueda por encontrarse a sí misma y una manera de ser libre: 
Estoy harta de tratar de parecer una más, de tararear las estúpidas canciones que todos tararean. Sé bien qué es la adolescencia y me rapo la cabeza para que entiendan que yo soy yo. Este sábado acabo de raparme la cabeza, dejando un poco de cerquillos y flecos sobre los lados. (Guerra, 2006, p. 126)

La autora descubre en Nieve esa capacidad silenciosa de afirmarse, la cual se presiente en su actitud de raparse la cabeza guiada por la ilusión de tomar sus propias decisiones. Asumir el proceso de maduración se convierte para ella en un intento de repensar y reformular sus actuaciones, sin despreciarse a sí misma, sin decepcionarse por mostrar preocupación por los problemas de su mundo privado, valorando su independencia, autonomía, voluntad, esencia y su particularidad, siendo consciente que su accionar puede producir efectos ideológicos, en una búsqueda por mejorar la opresión, por ser escuchada a través de sus acciones. "No quiero ser hippy como mi madre, no quiero Peace and love. Quiero ser yo. Ningún estado de ebriedad me parece necesario. Tengo quince años" (p.127). Nieve encuentra la supervivencia personal y quiere tomar decisiones.

Además, el diario de Nieve le permite expresar su realidad al tomar conciencia de su realidad, y esto la induce a aceptar la partida de las personas que marcaron hitos importantes en su vida. El primero fue Fausto, quien también era su padrastro, por él sintió un amor desmedido y finalmente lo expulsaron de Cuba y se vio obligado a regresar a Suecia. Después, es separada de su mamá y debe irse a vivir con su papá; con el paso del tiempo vuelve a reencontrarse con ella. Sus amigos, con los cuales escribió amores inconclusos: Alan, Osvaldo y Antonio, quienes también se van. Con Alan, Nieve tiene la experiencia del primer beso "Casi me muero de vergüenza, me pareció que su boca nunca se iba a desprender de la mía. Este es el primer beso de verdad en toda mi vida" (p.164). Wendy Guerra interpone en Nieve la experiencia inicial de los secretos del amor, dejando ver lo poético sin llegar a desbordar en la fantasía erótica ni dejar de lado su contenido 
emocional. Cuando Alan de aleja, "Se va de aquí la única persona que me invita a ser feliz con naturalidad" (p.209), Nieve, a pesar de que siente su partida, se va forjando poco a poco y descubre otros eventos importantes en su vida, como el amor, representado en Osvaldo y después en Antonio. Sus encuentros con Osvaldo la marcan para siempre, pues le permiten descubrir el placer de la vida sexual, desconocido hasta entonces. A través de un lenguaje que se puede considerar dentro de lo poético, Guerra narra este momento: "Ahora era yo un venado que nacía en pleno campo, envuelto en sangres y resinas, transfigurada por un bautismo de fuego, de virgen a diosa», (p.195). El erotismo contenido en la novela, revitaliza los espacios interiores en donde se gestan, entre sábanas y conversaciones cotidianas, los entramados que posibilitan las intenciones y recreaciones de una subjetividad que sólo es posible desvelar a través de la palabra literaria. Al reflexionar sobre sus sentimientos, Nieve construye el sentido de su existencia, develando su maduración. "No sé qué siento. Estoy perdida, no sé qué hacer con todo esto que almaceno dentro de mi alma. Algo está claro. En Cuba ya no tengo nada que buscar (...) Siento cosas muy raras, es como si se me estuviera acabando el país". (p. 217).

La transmisión de su mundo particular incorpora una sensación de abandono, de ruptura, que se va agudizando con la partida de Osvaldo, a quien finalmente termina condenándolo prácticamente al olvido, constituyéndose en una historia de amor relativamente corta. El recuerdo de Osvaldo tiende a desaparecer: "Hasta Osvaldo se va borrando de mi mente: llevo nueve largos meses sin verlo, hasta se me olvida la cara" (p. 218). Pero esta faceta de Nieve desaparece paulatinamente por el progresivo abandono que forma parte de su evolución en su proceso de individualización y que le permite finalmente adoptar su singularidad; ella no huye, pero se siente sola. "Mi libreta telefónica está llena de rayas rojas. Ya no puedo marcar esos números. Nadie me contestará. Casi no hay gente conocida en la ciudad. Todos se van. Me dejan sola. Ya no suena el teléfono. Yo espero mi turno, callada" (p. 223). 
La huella de la soledad también actualiza la realidad de Nieve, principalmente la sensación de desamparo que lleva a lo largo de su diario, donde se siente la voz humana, hecha de perturbaciones, de soledades.

Después, aparece Antonio en su vida amorosa y sexual: "Antonio me desnudó en plena sala, me hizo el amor sobre el suelo, dejando en la alfombra toda la humedad que los dos pudimos acumular, desesperados. Fue directo al lugar donde se encuentran todos mis placeres" (p. 240). Este encuentro con Antonio está recreado con un lenguaje no cifrado, develando su condición humana. Ciplijauskaité (1988) nos deja leer: "Un aspecto importante de la concienciación representada en esta novela, es el despertar del deseo sexual y su configuración” (p.55). Estos encuentros eróticos de Nieve con Osvaldo y después con Antonio hacen parte de su transformación, ya que le permiten reconocer los deseos que se exteriorizan en su juventud. Guerra nos presenta a Nieve como una mujer sensual, sumergida en una atmósfera de erotismo, como muestra de rebeldía contra las estructuras vigentes en la sociedad, en la búsqueda de otras técnicas narrativas, creando en su escritura un lenguaje femenino, que conlleva a tratar temáticas que tienen que ver con la vida interior. La escritora establece otras relaciones entre escritura y deseo, buscando expresiones que permitan vislumbrar el placer a partir del autodescubrimiento del cuerpo femenino y la revaloración de las sensaciones sexuales de la mujer en un mundo naturalmente cambiante.

\section{La maduración como ser social y político}

Todos se van abarca los años 1978 a 1990 y estas fechas proporcionan el contexto para la narrativa, pues si esos años fueron difíciles para Nieve y para todos los que la rodeaban, el Período de mandato de Fidel Castro durante los años noventa, sería aún más difícil. La obra refleja la dolorosa experiencia de la generación nacida en Cuba en la década de 1970 y busca desnudar 
las debilidades del tejido social cubano, donde la escritura se convierte en un resguardo para todos, incluso para Nieve: "Mi Diario es un lujo, mi medicina, lo que me mantiene en pie. Sin él no llego a los veinte años. Yo soy él, él es yo. Ambos sentimos desconfianza" (p. 129).

En la obra, puede rastrearse el conflicto cubano desde la problemática de la existencia de sus pobladores, otorgando a la escritura el acto creador y al mismo tiempo se convierte para Nieve en la perturbación de su propia conciencia, al poner en evidencia la cruda realidad de su país. Cada página la inscribe en el ámbito de la esfera pública, pues el diario, aunque es íntimo, tiende a reducir la brecha entre su vida personal y la realidad cubana. Nieve participa de la vida de su país y el diario se convierte en su refugio, una especie de resguardo que le permite reflejar su realidad a través de la escritura y al mismo tiempo es un testigo de su crecimiento, pues Nieve está empezando a asumir una conciencia crítica sobre la política, reconociendo los problemas de su país.

Mi madre me dice que si quiero vivir sin hablar de política tengo que irme a Canadá, a una aldea bien fría donde vive gente que tala árboles y ni se entera ni le interesa el nombre del presidente que gobierna ese país. En Cuba, según ella, la política está en lo que te comes, en lo que te pones, en dónde vives, en lo que tienes y hasta en lo que no tienes. No hay solución posible para mi madre: "Si quieres escapar de la política tienes que escapar de Cuba. (Guerra, 2006, p. 170)

Los registros que aporta el diario tienen sentido cuando giran en torno al destino cambiante de Nieve y de su realidad social y política, donde a través de un recorrido largo, muestra su descontento, su resistencia, algo que la devuelve a su ser femenino: callada, silenciada, erotizada, afectiva, compasiva, resignada, incomprendida, diluida, fragmentada, contradictoria

A través del lenguaje, Guerra plasma imágenes relacionadas con las palabras que inducen a examinar el funcionamiento de 
la evocación, sus límites y su capacidad creativa, pues a partir de la creación de cada personaje se refleja una búsqueda por la reconstrucción nacional pero, todos sus caminos fueron desviados; todos menos el de Nieve quien decide quedarse en Cuba, su único hogar. Como una posibilidad de resistencia, grabando en su diario, a partir de reflejos literarios, los principales acontecimientos de su vida, registrando detalles íntimos en sus páginas en ese camino de formación, es su única salida para sus alegrías, tristezas, miedos, enojos y soledades. Así lo señala Ciplijauskaité (1988): “El tiempo femenino es siempre personal, lo cual influye su percepción global del mundo y de la vida [..] y en este tipo de novela la memoria se vuelve fluctuante, entreverándose constantemente con la percepción actual" (p. 39-40). Las referencias subjetivas al tiempo, los ciclos, las repeticiones, o los paralelismos son estrategias de subversión del canon y pueden considerarse parte de los procedimientos antiépicos de la literatura femenina.

Abordar la novela Todos se van a través de las categorías presentadas por Ciplijauskaité devela la capacidad que tiene Wendy Guerra de acudir a los elementos categoriales de la novela de concienciación, al equilibrar constantemente el mundo interior de la heroína con su mundo exterior. A Nieve sus recuerdos la retornan al pasado, en un sentido lineal, pues la narración se convierte en la creación de momentos vividos sin interrupciones, pero con discontinuidades temporales que le ofrecen la oportunidad de indagar sobre sus propios procesos de formación, donde se esfuerza por reconciliarse con la vida a pesar de sus múltiples recuerdos, esos que le brindan la posibilidad de hacer la distinción entre su pasado y su presente, lo que permite tener un punto de referencia, pues los lectores tienen acceso a los recuerdos emergentes de la narradora a partir de una escritura que permite preservar la memoria reconstruyendo hechos históricos, porque la novela revela, en primer lugar, el viaje de Nieve a través del tiempo, porque tiene historia; esa que permite conservar el legado de su pasado. Para sus propósitos, la novelista se vale de historias insertas en contextos que acomoda en su narración 
mediante estrategias que permiten conocer todo su entramado. En segundo lugar, se precisa la apertura de otras formas narrativas que se muestran complejas, a través de una propuesta estilística, que se perfila con sello propio por el manejo del lenguaje y de la prosa que se develan en la medida en que Nieve plasma en su diario todas sus experiencias de vida.

Este discurso determina una identidad femenina a la vez que ofrece la posibilidad de analizar los cambios que sufre el personaje: Nieve se forma y se nutre bajo la influencia de factores como la educación, verdades de vida, arquetipos de la madre y del padre, la problemática de una sociedad, a través de una narración que permite la construcción de una identidad propia que se forja a través del tiempo; donde se hacen públicos asuntos que pertenecen a la experiencia de su mundo femenino, tales como su adaptación o inadaptación a la vida, sus primeras experiencias relacionadas con el crecimiento fisiológico, tomando conciencia de sí misma y el propósito de su vida. Al reconocer las fronteras entre el presente y el futuro, la transformación de Nieve adquiere una relevada importancia; sus aciertos o desaciertos le aportan a su formación

En conclusión, podemos decir que hemos considerado oportuno recurrir a las categorías propuestas por Ciplijauskaité para ejemplificar la escritura femenina contemporánea, donde la formación de la protagonista constituye el hilo narrativo y el eje de la trama. La construcción literaria mueve al personaje a través de sus acciones descritas, y nos demuestra que la literatura escrita por mujeres presenta sus propias estrategias de narración.

Que Wendy Guerra tuviese una conciencia de escritura como la que se deja ver en Todos se van, permite comprender el valor de la literatura femenina como un compromiso y búsqueda de identidad de la mujer, animando a sus lectores a seguir descubriéndola, porque se extiende mucho más allá de lo lingüístico y lo textual. $\mathrm{Su}$ importancia se refleja en las narraciones, en el imaginario 
simbólico, pues al cuestionar el valor de estas manifestaciones literarias, se convierte en un ejercicio fructífero, como una parte enigmática del personaje que habla en su ámbito social, político, cultural, histórico.

Esta narrativa invita a comprender la transformación de la protagonista, brindándonos la oportunidad de conocer el proceso de formación de Nieve Guerra, donde "Todos se van" se constituye en un ejemplo de novela de concienciación. La voz femenina audible se constituye como depositaria de un mundo simbólico donde quiere pasar como emancipadora página tras página, permitiendo que la novela revitalice la mirada sobre esta literatura a través de un proceso plasmado en escrituras significativas donde se asume la necesidad de seguir preguntando sobre estas representaciones literarias y las formas que las configuran. Hemos hecho especial énfasis en el aporte de estas categorías de la novela de concienciación, que pueden fomentar nuevos horizontes de percepción de la literatura escrita por mujeres, donde lo relevante es el proceso y el cambio de la protagonista que nos permite presenciar su desarrollo y crecimiento a través de la experiencia.

\subsection{El silencio como marca en el lenguaje femenino}

En Veladuras, una novela breve de María Teresa Andruetto, publicada en 2005 la protagonista Rosa Mamani, quien es también la narradora, se ocupa de trabajar en sus recuerdos con el mismo ritmo de su tarea manual, consistente en la refacción de imágenes y bultos sagrados por el método de la veladura. Rosa, ha sido declarada paciente psiquiátrica, afectada por el rompimiento de la familia y el posterior suicidio de su padre del que culpa a su madre. Inferimos de la novela que ella debe recomponer su identidad, para lograr una mejoría. Desde niña se ha identificado con la familia paterna sus tradiciones ancestrales, el orgullo por ser indígena y portar el apellido Mamani. "No sé qué cree usted ni por qué será que pasó esto de parecerme tanto a mi abuela Rosa, si es porque me pusieron su nombre, o es nomás porque así tuvo que ser" (p. 33). 
Al contrario, su madre y lo que ella representa es por decir lo menos, un fastidio, una discusión constante, una falta de caracterización, puesto que ni siquiera su comida es tan rica como la que saben hacer en el pueblo de su padre. La madre es blanca y Rosa, para su desgracia se parece a ella en cuanto a la fisonomía. Envidia a su hermana que es morena y luce como cualquier colla. Le guarda rencor porque juzga injusto que si la hermana se parece tanto a su progenitor apoye de esa manera incondicional a la madre sin poder valorar el vínculo con los hermanos de raza.

El conflicto es de identidad: cómo construir una identidad cuando esencia y apariencia no se corresponden, cómo construirla cuando las experiencias son traumáticas y el afecto pierde anclaje porque los seres amados, que deben señalar el camino decepcionan en vez de responder a las expectativas; cómo construirla cuando se es mujer y las mujeres del entorno son descalificadas como modelo a seguir. En Andruetto, la idea de la loca, como en la novela anterior, aparece aquí cuando la mujer tiene problemas para seguir estereotipos: Rosa debe copiar de su madre un modelo de identidad, pero se niega a hacerlo porque su madre, símbolo de lo femenino, la decepciona.

Entonces empecé a hablar de los muertos y buscaba estar con ellos y todo eso asustó a mi madre hasta que, de tanto andar por todas partes, se presentó a la oficina de gobierno y un doctor y la asistente me llevaron a la Casa de Descanso donde trabajaba el doctor Freytes. Entonces me internaron, y así fue como yo lo conocía al doctor. (Andruetto, 2005, p. 26)

Literariamente, esta figura de la loca es una figura de desvío, equivalente al loco en el plano de la realización masculina, pero no como la anormalidad propuesta por Foucault que revela la hegemonía de los discursos del poder, sino como una propiedad del ser femenino, que por su condición de género (no una elección individual) cae en la locura de manera natural. Queremos decir, cuando la mujer alcanza el estado de locura, no sorprende a nadie porque era uno de sus estados posibles, uno que era previsible 
desde el momento en que nació mujer. Esta chica que busca su identidad mirando al padre, pero equivocada en las razones para hacerlo, pues son tan concretas como la que une a las mujeres en el encadenamiento de prácticas y creencias que atan a la madre con la abuela y con la hija.

Biruté Ciplijauskaité (1988) propone el espejo de las generaciones como el mecanismo mediante el cual las mujeres componen su identidad copiándose de las otras mujeres: madre y abuelas en general. "La hija ve en la madre y en la abuela un ejemplo y acepta el destino que le imponen la familia y la sociedad” (p.202). Pero puede suceder al contrario, que la hija rechace la imagen de la madre como modelo para construir su imagen, y que entonces se produzca un espejo negativo, con un sentimiento de culpa por cuenta del rechazo a lo que debería ser más amado y admirado. Este es el caso de Veladuras. El mecanismo de identificación con el padre nace de una memoria inculcada por él en su familia su mujer y sus hijas- con quienes visita su tierra ancestral por navidades y en tiempo de carnaval. Rosa, es quien más ha aceptado esta tierra y estas maneras como propias, la comida, la música, el baile, el vestido, los olores, el paisaje, el ruido y el silencio la figura de la abuela que se llama Rosa como ella. Mientras tanto la familia materna vive en otra provincia que nunca visitan, abuelos lejanos de los que no conoce nada, pero Rosa piensa que si su madre no sabe cocinar como en La Quebrada, si no sabe cantar como las mujeres de allá, sino sabe hacer cacharros de barro para su propio servicio no está a la altura del padre y su pueblo.

El texto está construido de manera que se resaltan los elementos que juegan en contra de la identificación de una hija con su padre antes que con su mamá. Es una estrategia de autor, de manera que se deshabilita la imagen del padre aun cuando en la historia es justo él quien legitima el sentido de la existencia. Se casó con una mujer blanca que no sabe cantar, por la que debe aceptar un empleo de vigilante, lo que no involucra ninguna competencia nacida de su formación indígena. Es más, ese empleo 
exige habilidades que provienen de su existencia urbana como un ser sin identidad. También hace mal al convertir en amante a una mujer que su esposa y sus hijas aceptaron en el hogar como una desamparada a la que había que proteger. Y la madre la protegió y permitió que se acostara con su marido en sus narices, pero sólo hasta que estuvo embarazada cuando ella, como esposa, decidió que debían formar familia aparte. Nuevamente, la historia muestra esto como una situación normal, que no daña a nadie y mantiene las relaciones en paz, pero que, sin embargo, el lector no deja de cuestionar como comportamiento ilegítimo nacido de la posición machista que da la razón al padre por encima de los sentimientos de su mujer.

La bronca con mi madre empieza con eso que ella hizo. Si hubiera cuidado a mi padre, que era de ella y era de nosotras, él no se habría ido con Gregoria ni con nadie, pero mi madre insistió en que tenía que vivir en otra parte, y no fue capaz de hacer que él nos durara. (Andruetto, 2005, p. 41)

Psicológicamente, tampoco funciona la identificación elegida porque cuando Rosa rechaza a su madre y la culpa por la tragedia familiar, enloquece y debe permanecer muchos meses bajo tratamiento psiquiátrico. Porque además su lenguaje se muestra incapaz de dar cuenta de la historia. A través del relato, un monólogo, el lenguaje se suspende por innumerables repeticiones y justificaciones incapaces de dejar fluir la información. El primer enunciado tiene continuidad muchas páginas después, y a su vez, éste prosigue al final de un discurso que nunca cuenta la verdadera historia de Rosa, que nunca puede decir algo sobre su ser porque al contrario sólo expresa su "no yo" Que se parece a su madre, pero quiere parecerse al padre. Que se llama como su abuela, pero no logra comportarse como ella. Que ama a su padre, pero se ha ido para siempre. Que su madre tiene la culpa de que su padre se haya ido y luego se haya suicidado. Esas son las ideas que Rosa se repite en su cabeza y que repite en su discurso. El relato de los acontecimientos surge de manera muy gradual, para 
que el lector comprenda lo que realmente sucedió. Ese lenguaje muestra que Rosa está encerrada en sí misma, que todavía no puede hablar de lo que sucede y que falta mucho trabajo para lograr borrar el sentimiento de culpa y el de orfandad. Aunque estos usos discursivos le pertenecen naturalmente a las etnias orales, escucharlo en boca de Rosa, una chica que va a la escuela, parecería algo impropio de su condición de letrada.

En conclusión, creemos que la novela reproduce relaciones sociales en las que es posible reconocer las dinámicas de dominación y resistencia que naturalmente se crean cuando dominantes y dominados comparten el lugar propio y los esquemas construidos a partir del poder. El mundo postulado por la autora se constituye en escenario para circular prácticas lingüísticas que manifiestan complejidades lógicas tan significativas como la vida misma para ubicar el espacio de producción de las imágenes que rodean la construcción de la feminidad. Claro está que no hablamos de lógica formal sino de lógicas narrativas que deberían establecer un yo, un otro, un espacio y un tiempo, como ya se planteó aquí, pero también definir la ocasión, el conflicto y el grado de conciencia sobre el conflicto, nociones todas que permiten articular lo narrado con el fin de interiorizar la experiencia y la vida.

2.5 La escritura como deconstrucción del orden patriarcal: La azotea de Fernanda Trías

La azotea de Fernanda Trías es una novela publicada en 2001. En ella, Clara, la narradora, a través de una escritura fragmentada y ambigua nos cuenta los últimos años de su vida, los cuales han transcurrido en un encierro voluntario en la casa de su padre que recién ha enviudado de Julia, una mujer que sin ser madre biológica, se comportó como una buena madrastra. Clara es una mujer adulta al parecer bastante confundida, neurótica, manipuladora y resentida. En los años que lleva junto a él, ha logrado mantenerlo lejos del mundo, como si fuera su carcelera, pues de hecho la casa poco a poco se va reduciendo a 
una prisión en la que apenas se puede sobrevivir. La atmósfera es de precariedad. Clara está embarazada, al parecer de su propio padre y el lector puede intuir que fue ella quien tomó la iniciativa para que eso sucediera. Se ocupa de la administración de la casa y del dinero, de organizar los desperfectos cuando aparecen, de hacer las cuentas y planificar cómo sobrevivir. Se comporta como el hombre de la casa. Aunque está embarazada, logra ser, al mismo tiempo, quien pone las reglas en el mundo en donde viven porque su rol en ese espacio de aislamiento corresponde al de un varón.

Dentro de este escenario, Trías emprende la tarea de crear una historia con pocas marcas de feminidad, pero ello es sólo una apariencia. La autora usa la escritura rebelde, la escritura deconstructiva con el fin de hacer una crítica a las ficciones femeninas corrientes. Contrario al ideal de mujer afectuosa, dulce, comprensiva y pasiva, Clara encarna un estereotipo frío, calculador y agresivo muy poco apropiado como modelo de identidad femenina. Esta autora escribe de manera consciente y logra ponerse en contravía de los patrones escriturarios de la literatura tradicional. Biruté Ciplijaukausté cree que las autoras contemporáneas analizan los estereotipos sobre la feminidad y en sus obras no sólo se narran sino que cuestionan el universo patriarcal que las homogeniza y obliga a mirarse según determinados patrones (1988, p.17). Este es el caso de Trías y de muchas otras autoras contemporáneas, cuando se enfrentan a cambios en cuanto a los roles de las mujeres y el acceso a nuevas posibilidades de identificación y nuevos derechos como resultado de las luchas feministas y otras luchas sociales. Situarse entre este grupo de autoras requiere temas inéditos, lenguajes potentes, imágenes impactantes capaces de impresionar la sensibilidad del lector para llevarlo a pensar lo femenino con referencia a distintas posibilidades, de un lado, posibilidades abiertas desde el pensamiento de lo femenino, y de otro lado, posibilidades provenientes de la maestría escrituraria de las autoras. En el caso de La azotea se subvierten la imagen de mujer, la imagen de cuidado de los otros como característica fundamental de su 
ser, así como las referencias al espacio y al tiempo, al desarrollo lineal de las anécdotas y el logocentrismo y, en cambio, se recurre a personajes desquiciados, a construcciones de tiempo y espacio según líneas mucho más subjetivas y existenciales.

La heroína de Trías no administra la vida de la casa sino la destrucción de la casa. Todo el universo se reduce a una ruina, una casa sin vida aunque además de Clara y su padre en ella habitan una niña, la hija de ambos y un pájaro enjaulado. De vez en cuando viene Carmen para ayudarla con las compras y con algunos consejos sobre salud y vida cotidiana. No hay mucho más. Sin embargo, ella tiene unos pocos días buenos en los que siente que es posible ser feliz. Pero además de este personaje carente de norte, que parece sentir de manera equívoca, Trías subvierte otras estructuras del relato. Si bien las referencias de tiempo y espacio son construidas de manera objetiva en el universo racional patriarcal, la escritura deconstructiva de La azotea crea un mundo de ficción con reglas de funcionamiento autónomas. "No hay rambla ni plaza ni iglesia ni nada. Esta casa es el mundo" (p.14) le dijo un día Clara a su padre, cuando él todavía estaba interesado en salir. El espacio de la casa es recortado del mundo con una pequeña ventana y una azotea desde donde se puede contemplar el exterior, sólo que no están disponibles ni para el padre ni para Flor, la hija. A veces abre la ventana por el pájaro para que no se muera y sólo ella sube con frecuencia a la azotea. No hay vida posible, y en verdad la idea transmitida por Trías es la de unos personajes que, aunque todavía realizan algunas acciones, están ya muertos. También el tiempo transcurre según las coordenadas del presente. Para Trías, cada día es una especie de representación de una escena más del mismo drama de muerte en vida con el tiempo detenido, transfigurando la escenografía del pasado en hilachas para cubrir un segundo más de la agonía.

Llegó un punto en el que sólo pude pensar en presente. Lo único que me preocupaba desde que abría los ojos era cómo sobrevivir ese día. La guerra se llevaba a cabo minuto a minuto; no había 
espacio para la planificación. Teníamos que resistir cada momento hasta que cayera la noche. Entonces todo era diferente. El reino de Carmen se debilitaba y nosotros podíamos reponernos para empezar de nuevo a la mañana siguiente. (Trías, 2001, p. 99)

Ese tiempo dilatado que no se alcanza a superar en las vivencias tampoco se deja identificar porque no proviene de unos datos del pasado. Los recuerdos de Clara no alcanzan a justificar el estado de cosas de la actualidad del relato, de modo que la linealidad del tiempo se suspende.

Narrada en primera persona el yo narrador de La azotea puede plantear preguntas en relación con la subjetividad porque a pesar de toda la insania que la caracteriza, la conciencia de Clara en algunas ocasiones, deja traslucir la conciencia de Trías: "Quiero reconstruir la vista de la azotea, recordarla de forma tan perfecta que ya no pueda distinguir el recuerdo de la realidad" (Trías, 2001, p.48). O un poco más adelante continuando el hilo de su reflexión dice:

Un momento. Creo que había algo más detrás de la cúpula con estrella, una torre de metal entramado, roja y blanca. O puedo estar inventándolo todo. Lo de papá y el pájaro es verdad, lo de Flor también y eso basta. Puedo decir: un día Carmen entró volando por la ventana de la cocina; decir: los dedos se le habían convertido en cartílagos enormes, tenía plumas bajo los brazos y echaba espuma por la boca. ¿Qué me importa? No tengo nada que probar. Lo que sé, sólo yo lo sé y a nadie le interesa. (Trías, 2001, p. 49)

Parece la voz de la escritora filtrada a través de la garganta de su protagonista. La desorientación del personaje es capitalizada por una autora que parece preguntarse cómo construir la subjetividad, cómo plantear el yo de la narración para que pueda contraponerse al yo femenino de la vida real, incluido el de la propia autora. En un mundo social en el que roles masculinos empiecen a ser actuados por mujeres, es apenas natural que la identidad femenina deba ser 
puesta en cuestión por las autoras mismas a través de personajes que no sólo viven la acción de manera directa sino que mientras actúan interpretan como corresponde a una conciencia subjetiva lúcida. Ciplijaukausté nos ilustra así:

A esta clasificación habría que añadir las consideraciones de Lubomir Dolezel acerca de las facetas del narrador en primera persona: 1) el "yo" observador que presenta un relato casi objetivo, el cual se parece a lo que se escribe en tercera persona; 2) el "yo" retórico que une observación e interpretación, es decir que no está instalado completamente en el mundo personal; 3) el "yo" íntimo que observa, interpreta y actúa siempre desde una conciencia decididamente subjetiva. En la novela actual es más frecuente la tendencia hacia la voz verdaderamente personal del protagonista quien tiene menos interés en informar que en investigarse. El uso de superposición temporal, con asociación libre, permite mayor libertad y a la vez mayor ambigüedad. (Ciplijaukausté, 1988, p. 18)

En muchos libros escritos por mujeres, el yo femenino de la cultura patriarcal, para quien lo único seguro es el afecto, está amenazado por la demencia, pero al contrario de la locura de Alonso Quijano, por ejemplo, que como desarrollo de la posibilidad del yerro de una subjetividad emergente termina por abrir caminos a los héroes, la locura de la mujer es un punto de no retorno, una especie de castigo que auto-aniquila a quien la sufre y amenaza a quienes conviven en su entorno. El yo desquiciado de Clara no logra crear un proyecto de vida ni siquiera en clave femenina, pues no puede cuidar de sí misma ni de quienes están a su cargo. Su impulso vital creador se convierte en farsa como cuando su padre le suplica por una última vivencia de estar en contacto con el agua y los peces para revivir sus antiguas glorias de pescador, ella le trae a casa un acuario con dos pececitos de color. Es como si no pudiera crear un relato sobre sí misma y su proyecto de vida, como si fuese víctima de la dysnarrativia, que según Jerome Bruner es: 
Una grave lesión de la capacidad de relatar y comprender historias... Uno de los síntomas más característicos de tales casos es la pérdida casi total de la capacidad de leer el pensamiento ajeno, de comprender lo que los demás podrían pensar, sentir, hasta ver. Los enfermos parecen haber perdido el sentido de sí mismos, pero también el sentido del otro. (Bruner, 2013, p. 123)

Cuando interpretamos la situación de Clara como un caso de dysnarrativia y cuando las coordenadas de tiempo y espacio se subjetivan de tal modo que se hace imposible situar un proyecto de vida comprensible y justificable a los ojos de la tradición, entonces podemos situar la narración de Fernanda Trías con referencia a la antiepicidad, puesto que la épica exige que el relato se comprenda dentro de la mimesis que conecta la narración con la vida de tal modo que la acción en el relato y el destino del narrador se orienten a lo que la cultura acepta como canónico: un conjunto de reglas, unas virtudes apropiadas a la vida del ser humano, una determinada visión del mundo con sus coordenadas espaciotemporales, ideas de totalidad, leyes de existencia y un conjunto de creencias sobre la verdad, sobre el bien y el mal y sobre la dignidad misma del ser humano. Esas narraciones aparecen en la forma de un relato donde el objetivo es recomponer un estado de cosas, que por algún tipo de transgresión o alguna particular situación ha sido desequilibrado. Para la cultura occidental en la que las reglas tienen origen logocéntrico y patriarcal son los relatos de corte épico los que convierten la aventura particular del personaje en una gesta colectiva a la que se suman las simpatías y las expectativas del lector; por eso, esos relatos pueden conformar el bagaje literario que sostiene el entramado simbólico de la unidad social, la tradición y las instituciones.

Sin embargo, es posible creer que hay un tipo de literatura de carácter subversivo, capaz de orientarse no a lo canónico sino justamente a aquello que es posible esperar pero que aún no existe. Es la literatura de las minorías para quienes lo canónico es adverso: mujeres, indígenas, homosexuales, negros o cualquier 
otro grupo amenazado por la tradición. En el caso de esta novela la subversión comienza con el no proyecto de Clara, con su incapacidad para crear y para imaginar un futuro mejor. Con Bruner nos acercarnos a la descripción de esas manifestaciones de dominación::

Nosotros tratamos de domeñar este dilema admitiendo -y es bondad nuestra- que en efecto los relatos siempre son narrados desde alguna perspectiva en especial. El relato del triunfo del vencedor es el fracaso del derrotado, aunque ambos hayan combatido en la misma batalla. Ni siquiera la historiografía, como nos repiten los historiadores desde hace ya una generación, puede sustraerse a la perspectiva que domina su exposición narrativa. Denunciar una perspectiva no hace más que revelar otra. Y por más saludable que pueda ser como ejercicio crítico, esta denuncia no produce necesariamente una versión de la realidad por encima de las perspectivas, una vez admitido que una versión semejante llega a estar en algún momento a nuestro alcance. Y es así que nos consolamos concluyendo que es la conciencia de las perspectivas alternativas, no la mirada desde el Olimpo, la que nos hace libres de crear una visión correctamente pragmática de lo Real. (Bruner, 2013, p.42)

Cuando Trías subvierte los aspectos narrativos, para preguntar qué es una mujer, su mirada se hace crítica. Sin embargo, a pesar de ser una postura plenamente consciente la visión de Trías corresponde a una crítica sensible. Sus dudas, la ambigüedad presente en las situaciones relatadas, la compasión que siente ante las dolencias de su pequeña niña, la tendencia a echar sobre sus hombros los males y la culpa que sigue a ello, son parte de su yo narrador de carácter femenino que no puede desapegarse del todo de su sensibilidad de mujer. También lo son las marcas del lenguaje mucho más cercanas a la oralidad que a la escritura, en consonancia con la sensibilidad corporal antes que con la lógica intelectual. La circularidad del tiempo unida al método de la asociación es usada de manera intencional para deshacer el patrón tradicional de escritura. También lo hacen las 
analogías como cuando Clara dice que la vida de su padre y la vida del pájaro fueron vidas sincronizadas para significar que tendrían que terminar el mismo día. Los procedimientos subjetivos y afectivos presentes en la forma del relato de La azotea logran romper el orden de lo patriarcal a través de un narrador que vive y al mismo tiempo - aunque no de forma explícita- interpreta lo vivido. La voz de las autoras es más desafiante ahora que en el pasado, pues la actitud de las mujeres tampoco es de sumisión. Es posible escribir historias en las que la mujer se muestre tal como ella se ve a sí misma, viviendo un momento de construcción en el que hay más preguntas que respuestas, pero en todo caso por fuera de los patrones impuestos durante los largos siglos de la dominación patriarcal.

\subsection{Lo político como elemento configurador de la identidad femenina}

Lengua madre (2013) es otra novela de María Teresa Andruetto $^{1}$, en la que de nuevo la trilogía madre, abuela, hija compone una historia de develación y ocultación, pero esta vez, desde la conciencia lúcida de la nieta que una vez pasada la adolescencia teje una relación discursiva con su familia, tal como también la madre tendrá que hacerlo. Ambas la realizan desde la distancia y para ambas, es la memoria el dispositivo que elabora la afectividad. La autora no quiere hablar sólo de la problemática de la construcción de identidad en el espejo de las generaciones, que desde luego está planteado, si no que habla de la identidad política, en una nación que destruye la opinión personal, que persigue a los individuos, que impone ideas y desaparece a quienes se oponen a esas ideas dominantes. Además, Andruetto deja ver cómo la novela posee una intencionalidad política, pero está trabajada de manera bastante subjetiva, como vivencia enclavada en el corazón de los significados familiares y afectivos.

1 En el anexo $\mathrm{N}^{\circ} 1$ presentamos una entrevista con María Teresa Andruetto, con el fin de mostrar de manera directa su pensamiento en torno a la escritura femenina y lo que esta representa en nuestra contemporaneidad. 
Frustración de no poder abstenerse de todo sentimiento, para encontrar una manera de vivir en paz con su pasado. Cansancio, dolor, tristeza, tedio, entusiasmo también y también -¿por qué no?- breves relámpagos de felicidad... considera que todas estas emociones por las que va pasando están relacionadas con la lectura de las cartas, que deberá en algún momento separarse de ellas para poder razonar libremente, para lograr cierta distancia. (Andruetto, 2013, p. 73)

En Misia señora, Alba Lucía Ángel da su palabra a la nieta para denunciar la sociedad patriarcal al mismo tiempo que denunciar la pasividad de sus antepasadas, pero no deja de otorgar al cuerpo un lugar de primer orden, pues la más joven de las Marianas sufre múltiples violaciones. En Lengua Madre, en cambio, Andruetto -sin referir nada particular de la corporalidad femenina- dota a la memoria de una intimidad muy personal, donde un correlato discursivo, la correspondencia privada e inviolable de Julia, la madre, se convierte en una especie de bisagra entre lo individual y lo social. La memoria trasciende lo corporal y modela la identidad de cada vida - presente o no en la novela- como tocada por un mismo momento de la historia. En el mundo de la casa y en el mundo de la vida de los personajes hay solo presencias femeninas y la voz varonil aparece libre de violencias, enfocadas en un hacer afectivo y, si político, es un hacer animado de espíritu solidario. El relato comienza con la muerte de la madre de Julieta -Juliauna activista política en la Argentina de 1976, que a causa de la dictadura debió esconderse en el sótano de una casa de Trelew en la Patagonia. Allí en ese sótano, en 1978 dio a luz a su hija, lejos de su marido y compañero de lucha; lejos de sus padres, de sus amigos, de sus médicos, porque hizo parte de una generación que vivió bajo el imperio del miedo. No podía pasear por la casa más que un rato en las noches, no podía encender la luz, no podía asomarse a las ventanas y así permaneció durante unos diez años. Entregó su hija a los abuelos, permitió que su compañero se marchara dos meses después del nacimiento de Julieta, y admitió que su único contacto con el mundo se diera a través de una correspondencia básicamente con otras mujeres de la familia y 
del entorno cercano. "De manera que podría decirse que ella es hoy, a poco de morir su madre, una hija que la está buscando. Una hija que hace nacer una madre de entre unos papeles, unas cartas" (p.12). Pocos hombres entran en el circuito de la comunicación de la joven Julia, cuya principal proeza consiste en sobrevivir incomunicada y aterrorizada. Una carta de su padre, otra de su hermano, alguna de un compañero político. El resto, son misivas de su madre, sus amigas, su hermana, su hija.

El tema de todas las mencionadas anteriormente es el miedo, la inseguridad, las condiciones difíciles del país, pero también el amor y las consideraciones para reunirse un día con su amada hijita Julieta, cuya ausencia es el núcleo de la historia. Nunca llegaron a reunirse. Julieta abandonó el país antes de que su madre pudiera regresar. Antes de morir, la madre lega a la hija una memoria de su vida en un conjunto de cartas. El tema de la novela es la reconstrucción del pasado y la memoria personal de las nuevas generaciones a partir del recuerdo de la devastación social y política del país que la generación anterior tuvo que enfrentar. Julieta con sus escasos recuerdos del pasado no puede completar el mapa de lo que ella es, hasta que no lea la versión fragmentada de los hechos que su madre guardó para ella. Sin esa otra memoria no es posible construir identidad, al menos no para quienes vivieron la dictadura en Argentina desde 1976 hasta 1983. Antes de Videla, Argentina era el único país del Cono Sur en mantener un régimen democrático, comandado por el peronismo, pero la dictadura llevó a la desaparición de 30 mil personas, incluidos los niños hijos de las embarazadas detenidas como enemigas del régimen. El terror había comenzado aún antes del golpe de estado, pues los enemigos del peronismo se amparaban en la política de la Doctrina Seguridad Nacional proclamada por Estados Unidos y en la que también se sostenían Hugo Banzer en Bolivia, Alfredo Stroessner en Paraguay, Ernesto Geisel en Brasil, Juan María Bordaberry en Uruguay y por supuesto, Augusto Pinochet en Chile. 
En la medida en que se avanza en la novela es claro el propósito de hablar de lo que sentía la gente común en esos años de guerra sucia y miedo. Las precauciones que se debían tomar para gastar un poco de dinero, para matricularse en una escuela, para cambiar de dirección, para comprar una medicina extra, para hacer un viaje, para aparcar en una determinada calle, para inscribir un nombre en el registro civil. Los mecanismos de la oficialidad son la vigilancia, la persecución, la tortura, el espionaje y la desaparición forzada.

Podemos observar que lo planteado aquí no es un tema netamente femenino. En Respiración artificial ya Piglia (1993) se había preguntado cómo desde las vidas privadas y los archivos personales, se puede reconstruir la historia de un país. De hecho es un problema de la pragmática de nuestro tiempo con más respuestas en la práctica escrituraria que en la teoría. Sin embargo, lo femenino aflora cuando intentamos preguntar por el contenido de esa memoria, que resulta ser mucho más intimista en la literatura femenina que en aquella escrita por hombres. Ciplijauskité (1988) nos aporta otra estrategia narrativa para lograr estas indagaciones:

La narración en primera persona parece particularmente apropiada para lograr la impresión de una estructura viva; permite entregarse a la investigación constante, sirviéndose de la asociación libre y de las epifanías. Varias de estas escritoras intentan unir los movimientos del cuerpo con las modulaciones de la voz como expresión de lo más profundo de sus personajes. Tal acercamiento podría degenerar en una escritura excéntrica, o pecar de sentimentalismo. Lo evitan gracias a otro recurso de uso general: el enfoque irónico a través del desdoblamiento que permite la auto-observación crítica y posibilita el constante juego entre la fachada oficial y el ser íntimo. (p. 129)

Por desdoblamiento Ciplijauskaité entiende la tendencia de las mujeres escritoras a trasladar sus propias preguntas del presente a los personajes de la ficción histórica o política. Lengua 
Madre permite esa observación. La identidad de las nuevas generaciones no puede olvidarse de cómo hicieron los argentinos para mantener el tejido social dentro de un régimen de terror y la respuesta, aunque la novela no puede ofrecerla acabada, habrá de buscarse en la solidaridad. Dentro de la historia desarrollada en la novela, los varones parecen sumarse a la cadena solidaria, aunque eso los mantenga lejos de las posturas viriles. El cuidado de las cosas ajenas que el perseguido no puede cuidar por sí mismo, los circuitos de comunicación lentos y seguros, la existencia tranquila en medio de la precariedad económica haciendo de la creatividad una forma de supervivencia de aquellos que no forman parte de la oficialidad en el poder ni simpatizan con ella, son algunas rutas para mantener la cohesión. No hay enfrentamiento directo, crítica abierta o desafíos al régimen. Esas serían respuestas de héroes épicos que hacen de la guerra un escenario para enfrentar valores supremos y hacer de la existencia una causa a favor de un grupo de valores patriarcales. En este apartado vamos a focalizar la mirada en dos novelas que parecen ejemplificar la elección de estas dos formas de lucha, una indirecta y sutil y otra directa: comparamos el texto de María Teresa Andruetto con otro texto de Héctor Abad Faciolince en el que se recupera la memoria de uno de los progenitores, la madre en el caso de Andruetto y el padre en el caso de Abad, ambos enmarcados en el panorama sociopolítico de una sociedad violenta y convencidos de que la identidad propia se construye de cara a esos referentes parentales.

Miremos con un poco de detalle el libro de Héctor Abad, $E l$ olvido que seremos (2007). Se trata de un relato biográfico, en el que el autor rinde homenaje a la memoria de su padre a través de la escritura, pero también rinde un tributo de admiración a la clase de persona modélica que fue. Toda la historia se enfoca en ir mostrando cómo la integridad del temperamento de su progenitor lo fue acercando de manera inexorable a la muerte, pues en un país donde son tan corruptos y violentos los ciudadanos aislados como los dirigentes y los políticos, aquellos que defienden la solución pacífica de los conflictos y toman el camino de la denuncia, terminan por hacerse merecedores de la muerte. 
Al contrario que en Lengua madre, donde el afecto guía la búsqueda de la identidad y el talante de las relaciones familiares, en El olvido que seremos son justamente el intelecto y la razón quienes lo hacen. Por ejemplo, cuando Abad Faciolince quiere expresar el motivo de ser quien es, plantea una reflexión fundamental de carácter racional para resolver el conflicto afectivo originado en la posibilidad de ser hijo de otro hombre y llevar el apellido Maya en vez del suyo, heredado de su padre, “...en tal caso yo no me parecería a mi papá, sino a Bernardo Maya, entonces yo ya no sería yo, sino otra persona distintísima a mí, con lo cual dejaba de ser lo que era, y eso era lo mismo que no ser nada" (p. 61). Lo terrorífico de la situación es no tener los genes del padre, no algún secreto o algún asunto en relación con la madre. Lo que hace ser a este hijo lo que es, es su parecido con el padre, tal como ha sucedido para muchos varones de la historia literaria y de la historia de los pueblos, puesto que el patriarcalismo garantiza el éxito del padre a quién se forma con los valores de su progenitor.

Aunque escrito en primera persona, el libro sostiene un tono objetivo desde el comienzo hasta el momento del desenlace final, cuando el autor se abandona a la emoción por el recuerdo de la muerte de su padre. De hecho, la historia comienza con una descripción sobre las jerarquías familiares, luego el espacio, la calle, la casa, el barrio. Continúa con el cuadro del carácter de las personas importantes de su niñez y aunque no se pueda afirmar que las convierte en un conjunto de atributos adheridos a un nombre propio, parecería que aparecen en el relato por la necesidad de orden escriturario objetivo impuesto sobre la memoria. Por orden escriturario me refiero al procedimiento lógico y metódico elegido por Abad Faciolince para comunicar su memoria. Es como si a la necesaria sensibilidad ligada a la pérdida, el rencor y la impotencia se la negara en aras de una visión más intelectual de los problemas y debido a ello el plan de escritura tuviera que convertirse en una exposición ordenada de los hechos, en forma de antecedentes, hechos y consecuentes. Pero no. Cada parte de la historia se plantea en acuerdo con una forma racional 
muy clara: la de la dualidad, pareja de opuestos que convoca a las potencias racionales para entender el mundo. Miremos el relato del ascendiente familiar en el capítulo trece. Los párrafos que cuentan quienes son sus antepasados se enuncian así: "Esta guerra sorda de convicciones viejas y convicciones nuevas, esta lucha entre el humanismo y la divinidad venía de muy atrás, tanto en la familia de mi mamá como en la de mi papá” (p. 69).

A continuación, en unas tres páginas cuenta historias sobre sus abuelos maternos que dejan ver de manera muy sucinta cómo llegaron a configurar esa influencia sobre el último vástago que ahora cuenta la historia. Luego hace lo propio con la rama paterna de la familia, tal como si en un escrito de carácter explicativo dijese: para comprender este problema es necesario que, primero consideremos $\mathrm{X}$ y segundo consideremos $\mathrm{Y}$. No queremos afirmar que el texto está mal planteado o que su lectura sea pesada antes que amena, de ninguna manera, pues es un libro que merece todo nuestro respeto y atención. La única pretensión es la de mostrar la obviedad del procedimiento racional usado para su confección como texto pensado para libro. El otro elemento, el de las oposiciones binarias aparecen en este mismo capítulo, donde las más sobresalientes son: Hombre Vs Divinidad /liberalismo Vs conservatismo /Tradición católica Vs Ilustración jacobina.

En otros capítulos encontramos nuevas oposiciones como Ciencia Vs Superstición y Teoría Vs experiencia para hablar de la profesión de su padre; Padre Vs Madre y Razón Vs Sensibilidad para hablar de la familia. Son oposiciones corrientes que funcionan para nosotros en nuestras prácticas de vida cotidiana y nuestras prácticas cognitivas, pero lo interesante aquí es que funcionan como principio organizador de la memoria y como mecanismo de escritura, pues se hacen explícitas y se colocan como motivo de las experiencias personales del narrador, que preceden a toda su experiencia y luego de contar las anécdotas subsisten incólumes. Su significado se obtiene justamente del sistema de oposiciones. Dice Hélène Cixous (1979) en su libro La risa de la medusa: 
El pensamiento siempre ha funcionado por oposición, Palabra/ Escritura; Alto/Bajo. Por oposiciones duales, jerarquizadas, Superior/Inferior. Mitos, leyendas, libros, Sistemas filosóficos. En todo (donde interviene una ordenación, una ley organiza lo pensable por oposiciones (duales; irreconciliables, dialécticas) $\mathrm{Y}$ todas las parejas de oposiciones son parejas. ¿Significa algo eso? (p. 14).

De entre todos los personajes y a pesar de que el Doctor Héctor Abad es abanderado de todo lo que representa el verdadero humanismo, la completa y clara razón, la necesaria integridad humana, el grado de liberalismo y ateísmo justo para transitar dignamente por la vida, sólo él, como padre alcanza la dimensión humana de un personaje literario, esa que logrará arrancarlo del olvido, puesto que es amoroso más allá de toda sensatez racional posible, pero la relación entre el narrador y el padre idealizado se realiza a través del intelecto describiendo del afecto su inmensidad y fidelidad. Al hablar del amor intenta describirlo a partir de cuantificadores, lo analiza, lo compara y aunque declare que ha de sentirse visceralmente, convierte la idea del amor en un concepto al que se aplican operaciones del pensamiento racional. Sucede a lo largo de los distintos episodios del texto, pero es bien notorio en el capítulo 32 cuando narra el estado de ánimo de su padre después de la muerte de su hija Marta a raíz de una prolongada enfermedad que él como médico no pudo remediar, así lo expresa:

Estoy seguro de que mi papá no padeció la tentación del martirio antes de la muerte de Marta, pero después de esa tragedia familiar cualquier inconveniente parecía pequeño, y cualquier precio ya no parecía tan alto como antes. Después de una gran calamidad la dimensión de los problemas sufre un proceso de achicamiento, de miniaturización pues a nadie le importa un pito que le corten un dedo o le roben el carro si se le ha muerto un hijo. (Abad, 2007, p.178)

Surge inmediatamente el deseo de objetivar el afecto a través de la cuantificación y la comparación. En el escritor parece ser un hábito juvenil dejar a la razón la tarea de enfrentar las ideas 
sobre espiritualidad y el más allá o emociones como la tristeza y el miedo. Eso se hizo manifiesto cuando dejó de lado todo lo que tuviera que ver con las creencias religiosas a las que alude no como objetos de la fe sino de la razón. "Yo no me quiero ir para el Cielo. A mí no me gusta el Cielo sin mi papá. Prefiero irme para el infierno con él" (p. 12). El chico no siente temor, no tiene dudas en su planteamiento, sólo decide que en los asuntos de la religión las cosas serán del modo en que las plantea su papá. Desde muy temprano en su vida tiene claro que entre fe y razón existe una lucha en la que toma parte por la razón: "Yo sentía como si en mi propia familia se viniera librando una guerra parecida entre dos concepciones de la vida, entre un furibundo Dios agonizante a quien se seguía venerando con terror, y una benévola razón naciente" (p. 69).

La identidad del joven Héctor Abad se construye de cara a un progenitor con voz social audible, lo que terminará por llevarlo a la muerte. Un padre que luchó no sólo por la familia, sino por el país entero, al que le reconocía grandes ventajas, pero también enormes vicios. El doctor Héctor Abad vivió animado de una tremenda compasión hacia los más pobres y necesitados, al igual que una cierta desconfianza hacia los más poderosos y pudientes. A esa sensibilidad particular se le unía una clara inteligencia no sólo sobre los problemas médicos sino para las actividades políticas, las pedagógicas y periodísticas:

En todo cuanto escribía uno podía sentir su marcado acento humanista, emocionado, vibrante. Luchaba por medio de una voz enterada y convincente, para tratar de que todas las personas, ricas y pobres, despertaran y se empeñaran en hacer algo por mejorar las inicuas condiciones del país. Lo hizo hasta el último día de su vida, en un intento desesperado por combatir con palabras las acciones bárbaras de un país que se resistía y se resiste a actuar de otra manera que no sea manteniendo las enormes injusticias que existen, y defendiendo esa injusticia intolerable como sea, incluso asesinando a quienes quieren cambiarla. (Abad, 2007, p. 219) 
Así que el narrador reconstruye en la memoria el modelo que le permite comprenderse a sí mismo. Ocurre en muchas novelas de concienciación o de iniciación, incluidas muchas novelas femeninas escritas por mujeres, pero aquí el modelo es claro no sólo como padre que se copia en su hijo, sino que es modélico en lo moral, lo laboral, lo familiar un ser humano cabal, poseedor de los valores más deseables para vivir una existencia digna y confiable para otros. Una figura pública lo es en virtud de que asume o denigra los valores propuestos, pero se reconoce a sí mismo porque desde la antigüedad ha sido definido en sus roles, en su práctica ciudadana, así como en la intimidad familiar. Guerreros, chamanes, funcionarios, intelectuales, escribas, artesanos $\mathrm{y}$ creadores, cualquiera sea la función existen reglas y normas para regular el comportamiento, los sentimientos y las opiniones de todos ellos de tal modo que la referencia se mantenga a lo largo del tiempo. Los discursos de la filosofía y del derecho dibujan un mapa muy claro acerca de los códigos de honor, la vida buena, la moral, los derechos y deberes de la ciudadanía. También la literatura occidental clásica desde la Ilíada y la Odisea, hasta las obras épicas del medioevo y la modernidad, pasando por la Biblia familiarizan los significados del universo del ser y del hacer, que cuando se trata de los varones son claros y puede accederse a ellos de manera lógica y racional.

En cambio, no son tan claros los significados en cuanto al ser y el hacer de las mujeres. Se les relega al universo doméstico de rol de madres y esposas los únicos que cuentan con modelo oficial. Las mujeres de nuestro tiempo que salen a la esfera pública y cumplen una función en ella no tienen un modelo oficial todavía. Su experiencia del mundo, sus lenguajes son de poca utilidad en el trabajo, así como su sensibilidad, su inclinación a involucrar las emociones en el escenario laboral e involucrar los contextos en la proyección de sus acciones. Como los niños aprenden de sus padres, las niñas aprenden cómo ser mujeres de sus madres. Así copian el lenguaje y reciben lecciones de vida. A través de cuentos, canciones, oraciones, advertencias. De Julieta dice Andruetto en Lengua madre que: 
Más que leer descifra, interpreta en las cartas las preguntas y respuestas que con respecto a ese tiempo se dieron su abuela, su madre, las amigas de su madre, su tía... traduce lo que ellas dicen haber sentido, lo que escribieron. Lo hace intentando no traicionarlas, no traicionarse. Lee signos, marcas -leves pero indelebles marcas- de mujeres, en papeles, en pañuelos, fotografías, dibujos y tarjetas... como en el idioma secreto de las mujeres chinas. Lee y se inserta en una genealogía de la que es parte. (Abad, 2007, p. 189)

Lengua madre se ocupa de reconstruir procedimientos femeninos para hablar del universo objetivo y expresar pensamiento político desde una narración emotiva que usa la memoria casi como si fuera una cura contra el dolor, una especie de terapia para recuperar paz interior. De ningún modo rescata esas voces y esas figuras para que otros las sientan y perciban como personajes ejemplares de su mundo, pues las autoras de algún modo valoran los universos subjetivos como superiores a los universos donde los lazos entre humanos permanecen en la exterioridad de las personas. Julieta no ama a su madre porque su persona haya sido o pueda ser un modelo social o político para otros, y no intenta convertirla en heroína. La postura política de su madre es lo que siempre tuvo claro y lo que menos le importó a Julieta. Ella quiere recuperar su vida afectiva, recomponer la imagen de Julia para comprenderla desde el amor. Conocer a las personas es abarcar su sensibilidad, acoplarse a ella por un mecanismo mimético, para nada intelectual.

Cuando en la novela el narrador accede a los sentimientos de Julieta describe sus sentimientos acerca de los personajes al mismo tiempo que los presenta en su aparecer sensibles.

$\mathrm{Su}$ abuelo era gerente de una cooperativa que funcionaba en una casa vieja con techos de cinc y tirantes de madera, y su abuela una mujer cariñosa que nació y se crió en un pueblo próximo a Aldao y que amaba a su marido como a nadie en el mundo. Recuerda a su abuelo trabajando ante un escritorio -los biblioratos sobre 
precarios estantes- y no puede ahora ni pudo nunca imaginarlo niño; tiende a pensar que ha sido siempre un hombre grande y un poco triste, un hombre ya completo en la memoria, como lo veía entonces. En cambio, a su abuela sí puede imaginarla corriendo por el campo, pequeña y descalza. Ella cree que su abuela sí pudo haber sido niña alguna vez. (p. 57)

A lo largo de esta obra, que incluye el fragmento como pieza para la reconstrucción del universo de los acontecimientos que tejen la historia, que involucra la duda, que registra el avance del tiempo a través la edad o el lucir joven o viejo antes que con fechas o datos numéricos, la imagen de ser humano que aparece es la que puede subjetivarse a partir de la emoción. "Lengua madre", el título de la novela, parece aludir a ello, al hecho de que heredamos una lengua y hemos exaltado su poder para la referencia paradigmática cuando lo más importante pudiera ser la comprensión de la vida de cada quien dentro de la unidad de un relato de entrecruzamientos y afecciones.

\subsection{La crónica como escritura femenina para tiempos difíciles}

Ahora queremos referirnos a otra clase de narrativas donde la escritura femenina ha tenido un desarrollo e impacto relevante. Particularmente en el campo del periodismo narrativo, también la mujer ha desplegado toda su capacidad investigativa y crítica para develar a través de crónicas y reportajes, la realidad social y política. En las últimas décadas del siglo XX y las primeras del siglo XXI, estas escrituras han sido difundidas y han obtenido mayor reconocimiento, dado que evidencian el rigor y profesionalismo tanto en la investigación periodística como en el oficio de narrar. Escritoras-periodistas, han hecho visible, a través de la literatura de facto las historias de aquellas, también mujeres, que como víctimas o victimarias, esposas, madres, compañeras, hermanas o hijas han participado de los procesos de revolución, emancipación, luchas o conflictos. Por ello, en nuestro trabajo de investigación, algunas de las crónicas escritas por la mexicana Elena Poniatowska y las 
colombianas Patricia Nieto y Patricia Lara han hecho parte del objeto de estudio. Consideramos que sus crónicas ofrecen una narrativa singular con los matices específicos de la antiepicidad; en ellas evidenciamos una clase de relato, muy diferente al molde clásico, que en lo referente a la crónica masculina tradicional (nos referimos a la mayoría de las crónicas de los colombianos Alfredo Molano, Germán Castro Caicedo o incluso, Juan José Hoyos) ha sido más propensa a retratar el lugar protagónico de los hombres, ya sea como víctima o victimario, héroe o antihéroe, $y$ a visibilizar su reconocido y valiente liderazgo, su capacidad combativa y épica, casi siempre dispuesto para la guerra. ${ }^{2}$

Las crónicas femeninas abordadas en nuestro análisis, por el contrario, se encargan de desvelar la intimidad, la sensibilidad y las pasiones; -entre otras-, características esenciales de la antiepicidad, que también están presentes en la crónica en general, cuando de algún modo se orienta a la visibilización de los débiles y oprimidos, los que no cuentan en las historias oficiales, en la Historia con mayúscula; los grupos subalternos, los diferentes, los representantes de la alteridad.

Es un hecho que las mujeres han sido excluidas consuetudinariamente de las narraciones oficiales, no obstante, haber ocupado desde los orígenes de los conflictos, un papel preponderante en los acontecimientos sociales, culturales y políticos; han participado en grupos guerrilleros o revolucionarios y han asumido también roles protagónicos, inclusive de liderazgo político, a la vez que han sido víctimas, ya sea de violencia sexual, violencia de género o violencia intrafamiliar; han sido declaradas, madres cabeza de familia, también convertidas en desplazadas,

2 Dice en Tres Guineas Virginia Woolf, que el matrimonio es la única gran profesión abierta a las mujeres, desde el principio de los tiempos. "El matrimonio, arte de elegir el ser humano con el que compartir satisfactoriamente la vida, forzosamente nos habrá enseñado algo al respecto. Pero aquí nos tropezamos con otra dificultad. Ya que si bien es cierto que ambos sexos comparten, más o menos, muchos instintos, el de luchar ha sido siempre hábito del hombre y no de la mujer. Las leyes y las costumbres han desarrollado esa diferencia, ya innata, ya ocasional. Raro ha sido el ser humano, en el curso de la historia, que haya caído bajo un rifle sostenido por una mujer; la gran mayoría de los pájaros y las bestias, han sido muertos por los hombres". Woolf, 1999: p 14-15). 
huérfanas y viudas. Son precisamente esas condiciones las que se revelan en algunas de las crónicas escritas por Elena Poniatowska, Patricia Nieto y Patricia Lara. En ellas se referencian y describen con mayor profundidad aquellos aspectos que tienen que ver con la condición humana de aquellas mujeres, que como víctimas o combatientes han tenido su lugar en la guerra; y cómo desde lo que podría llamarse una actitud resiliente asumen su dolor.

En las crónicas femeninas analizadas, los elementos poéticos se convierten en un recurso cargado de imágenes que le permiten al lector penetrar el espacio íntimo del dolor que la noticia escueta o el hecho consignado en la crónica tradicional no logra comunicar. Este recurso a la intimidad de los sujetos protagonistas se vincula con otra gran temática favorecida en las letras femeninas, que es justamente el lugar natural de la intimidad: el hogar. Como escenario literario, este ha sido el epicentro de la afectividad, pero raramente los varones se han ocupado de él en las crónicas, dado que allí no se libran combates definitivos ni se efectúa un trabajo que pueda ser asimilado bajo un criterio racional: "ellas sienten más la vida, los hombres más la muerte; ellas piensan más en los hijos, los hombres más en las mamás" (Molano, 2016 p. 25).

De acuerdo con estas consideraciones, encontramos que la antiepicidad es una categoría presente en las crónicas escritas por las autoras escogidas, la cual se despliega a través de una clara "perspectiva de género" implícita en los relatos que destacan la vida de las guerreras, subversivas, beligerantes, mujeres que le han apostado al combate, estando al frente de la batalla, ya sea como victimarias o como representantes de la institucionalidad; pero asimismo, las crónicas hacen evidente el papel de la mujer como víctima o lideresa revelando su trabajo incansable en la reconstrucción del tejido social, en la recuperación de la memoria y en los procesos de reparación simbólica, tan importantes para alcanzar la paz en las zonas afectadas por los conflictos sociales y políticos. Sin embargo, la referencia a estas mujeres, a sus nombres, a sus roles se ha desestimado de la Versión oficial de la historia; 
por ello, hemos decidido destacar para el proyecto también estas narrativas, que le ofrecen al lector una visión diferente de la realidad épica del mundo real. Para nosotras, son relatos claves, no solo por su impacto en la reconstrucción de la memoria, sino como muestra de la emergencia combativa de las mujeres, como narradoras y testimoniantes de esas historias ignoradas.

Con Correa (2011) coincidimos en que la crónica es un género complejo, dado que conjuga elementos de la literatura y el periodismo que en ocasiones lo hacen difícil de poder caracterizar o clasificar; sin límites o fronteras, las crónicas han sido consideradas además, géneros menores o seudogéneros, géneros híbridos, o géneros mixtos, dado que le ofrecen al lector versiones que informan sobre la realidad pero desde una posición que muchas veces es subjetiva y particular. Así, la crónica escapa al formato tradicional, pues cada vez se deja permear no solo por la intención del cronista, de lo que pretende desvelar, también por lo que deriva de la emergencia de esas nuevas subjetividades que desean expresarse. En los años sesenta y setenta, por ejemplo, la crónica se abre a una opción que además de estética es política. Oviedo (2012), la denominó "Literatura en tiempos difíciles", una especie de discurso de resistencia de los grupos subalternos, dirigidos hacia una opinión pública internacional con el fin de denunciar aspectos o acciones que los sectores dominantes ocultan, los objetivos hacen de esta narrativa un discurso radicalmente alejado de los textos coloniales.

En Colombia, el surgimiento de la crónica femenina que se atreve a desvelar los tiempos difíciles de luchas, violencias, emancipaciones, crisis sociales y políticas, se presenta hacia finales de los años 60, cuando aparecen las propuestas de escritoras y periodistas como Elvira Sánchez Blake, Laura Restrepo, Olga Behar, Silvia Galvis o Constanza Ardila; quienes a través de sus textos empiezan a ofrecer otras formas de narrar, otros temáticas a abordar, logrando con ello la emergencia de nuevas representaciones de esa historia nacional y otro tratamiento para 
las violencias y los conflictos que envuelven al país. Antes de esto, -según lo plantea Mary Luz Vallejo Mejía-, la época dorada de la crónica en Colombia, se da entre los años 1910 a 1960, pero allí las escritoras escasearon: "en este período que abarca el estudio, cuando las mujeres eran vistas como bichos raros en las redacciones, lo que apenas era obvio teniendo en cuenta el machismo reinante en el país...ni siquiera las pocas mujeres que escribían abanderaban la causa feminista" (1997, p.11). No obstante, Vallejo destaca el trabajo realizado por cronistas como Emilia Pardo Umaña, Sofía Ospina de Navarro, Rocío Vélez de Piedrahita, quienes utilizaron en sus textos estilos costumbristas, muy propios de la época, muy amoldados a los relatos tradicionales.

Por fortuna, la intención de comunicar no se quedó allí, siguió emergiendo de diferente manera, con las propuestas narrativas de escritoras y periodistas que en las últimas décadas del siglo $\mathrm{XX}$ y las primeras del siglo XXI empiezan a desvelar el universo femenino, sus momentos de crisis, violencia política, guerras y conflictos; estas nuevas narrativas evidencian aspectos sensibles, que muchas de las crónicas masculinas tradicionales no se atrevían a mostrar. En estos relatos sobre el universo femenino en tiempos difíciles, se ofrecen otra clase de realidades, muy diferentes a las ya difundidas desde los modelos patriarcales, claramente orientados a destacar el liderazgo valiente de los protagonistas, varones beligerantes, dispuestos a dar cuenta de los avatares de las guerras y los conflictos.

En la actualidad, podemos decir que las crónicas de Patricia Nieto y Patricia Lara, así como de Elena Poniatowska, son propuestas que encajan perfecto en esos rasgos, en esos matices que hemos venido describiendo de la crónica como texto literario y periodístico, como género híbrido, que sirve también a la intención de la denuncia, y sobre todo, dan cuenta de la antiepicidad como categoría central que advierte sobre voces y cuerpos que se desnudan, para alentar la emergencia de lo subjetivo, lo poco mencionado, lo confinado al sentimiento y al olvido. 
En lo referente a los relatos de Elena Poniatowska, que nosotras ubicamos aquí como crónicas, particularmente Las indómitas (2018) se han considerado por una parte de la crítica literaria como ensayos que "describen la miseria, la impotencia, la humillación, pero también el tesón y la entereza, temas todos que atañen a la condición humana, protagonizados por mujeres que se han atrevido a transgredir, a ir al frente, cual Adelitas dispuestas a dejarlo todo en la batalla..." ( Poniatowska, 2018, p.9). No obstante, a nuestro modo de ver y de leer, consideramos que estos relatos coinciden con la crónica contemporánea, la cual, según Linda Egan, es:

El reportaje narrado con imaginación, de forma híbrida, cuya identidad genérica se ha de encontrar en la manera en que su función y su forma, persiguen sus metas inseparablemente. Por una parte la crónica reclama ser un género-verdad que pertenece al campo del periodismo. Al mismo tiempo, el uso ostentoso que hace de la técnica narrativa la alinea con el terreno de la escritura creadora. (Egan, 2008, p.141)

Y de acuerdo con Liliana Weinberg, estudiosa del ensayo literario, afirmamos nuestra posición de ubicar los relatos de Poniatowska, en el género de la crónica:

¿Quién decide la adscripción genérica de lo que se está leyendo? Por una parte, para seguir una línea afín a las cuestiones de recepción, se podría decir que se trata de la decodificación que hacen los propios lectores; esto es, para algunas corrientes teóricas, serían los lectores quienes decidirán en qué marco colocar el texto que tienen ante sus ojos. Pero, por otro lado, sabemos bien que detrás de los lectores están las formas de leer de una época, una cierta comunidad hermenéutica, un campo específico. Y sabemos también que hay, en el propio texto, marcas, indicadores, convenciones, que conducen a acuerdos de lectura y de legibilidad, a contratos de veridicción, y que son también decisivos para la legibilidad de un texto. (Garza, 2007, pp.271-287) 
Insistimos entonces en que las crónicas femeninas aquí analizadas quitan el velo, tejen una imagen desacostumbrada de la realidad en la que vemos surgir sujetos femeninos construidos no sólo desde la conciencia objetiva, sino también desde el sentimiento y la afectividad. Miremos por ejemplo el siguiente relato en Las Indómitas de Poniatowska.

Por allá en el monte los soldados nos hacían unas cuevas de piedras donde nos metíamos, él nunca me dejó que me desvistiera, no nunca; dormía vestida con los zapatos puestos para lo que se ofreciera a la hora que se ofreciera; el caballo ensillado, preparado para salir. Venía él y me decía: “ ¡Acuéstate!¡Ya levántate, prepárate porque vamos a salir para donde se nos haga bueno!” Yo nunca me quité los pantalones, nomás me los bajaba cuando él me ocupada, pero que dijera yo me voy a acostar como en mi casa, me voy a desvestir porque me voy a cobijar, eso no; tenía que traer los pantalones puestos a la hora que tocaran: ¡Reunión, alevante!, pues vámonos a donde sea...mi marido no era hombre que estuviera apapachando a una, nada de eso, era hombre muy serio. (Poniatowska, 2018, p.29)

Muchas de las crónicas escritas por mujeres sobre conflictos sociales y políticos, referencian y describen con mayor profundidad aquellos aspectos que tienen que ver con su ser, con su intimidad e identidad personal, inclusive en momentos de crisis, mientras que los cronistas se concentran en desplegar una mirada hacia elementos racionalizantes y en su consideración, necesarios para clarificar las situaciones, establecer cronologías y proponer versiones sobre los acontecimientos. El surgimiento de grupos guerrilleros, por ejemplo, los encuentros bélicos, las luchas por el poder son temas preferido por algunos de los cronistas hombres, mientras que en las crónicas escritas por las autoras elegidas para nuestra investigación, sobresalen las referencias a los espacios íntimos, familiares, la construcción de sus relaciones sociales y la descripción de los diferentes roles que les ha correspondido asumir; la actitud y respuesta ante las diferentes violencias. En Las indómitas Poniatowska, hace una descripción de las soldaderas 
o también llamadas Adelitas, mujeres que tuvieron un papel destacado en la revolución mexicana; sin embargo, la historia oficial poco hizo mención de ello. En la crónica sobre Josefina Bórquez, Vida y muerte de Jesusa, la cronista destaca particularmente la cotidianidad de una mujer anciana, maltrecha por el paso de los años, heroína de guerra, quien no solo acompañó a su marido Pedro Aguilar, también hizo su aporte a la revolución, pero la historia se encargó de invisibilizarla, el que se hizo famoso fue su marido, de ella poco se sabría si no fuera por las crónicas de Poniatowska.

Y es que en las referencias que hace la autora al lugar de la mujeres, las muestra precisamente desde esa antiepicidad que destaca todas esas características subjetivas que están ahí presentes en los seres humanos, como en una épica del yo interior, que difícilmente emerge; pero que sin lugar a dudas encuentra refugio en la palabra que le es concedida por la cronista, la que se encarga de hacer relevante su voz, a través del testimonio:

Me voy a vestir de hombre a ver si me va mejor". Muy bravas algunas se cortaban las trenzas y echaban su sombrero para adelante para que no les vieran "lo mujer" en los ojos. ¿Qué les sucedía a las mujeres que emulaban a los hombres? Ser hombre hacía la vida tolerable. Así lo comprendió Ángela Jiménez, experta en explosivos, espía y a veces cocinera, pero sobre todo veterana de guerra. (Poniatowska, 2018, p.68)

Lo que logran las cronistas es precisamente humanizar hechos y circunstancias en las que otras mujeres se resuelven víctimas de unas realidades históricas y sociales, lo que ellas describen son todas aquellas realidades que muestran la dolorosa y dramática condición humana de quien doblemente ha padecido la exclusión en el poder, la violencia, política, la guerra y la negación, casi total, de sus derechos: 
Al fin de cuentas, yo no tengo patria. Soy como los húngaros, de ninguna parte. No me siento mexicana ni reconozco a los mexicanos. Aquí no existe más que pura conveniencia y puro interés. Si yo tuviera dinero y bienes, sería mexicana, pero como soy peor que la basura, pues no soy nada. Soy basura a la que el perro le echa una miada y sigue adelante. Viene el aire y se la lleva y se acabó todo. (Poniatowska, 2018, p.25)

Estas crónicas femeninas emergen impulsadas por un mundo en crisis, en el que la solidaridad de las cronistas con los marginados o excluidos es mucho más clara, así como la posición política que deviene, mucho más evidente.

Si bien se sabe, la crónica ha sido clave en la recuperación de la memoria, asimismo ha sido considerada literatura de resistencia, en doble vía ha permitido la emergencia de nuevas identidades asociadas a la opción de permanecer abierto a otros sin evadir la responsabilidad sobre lo bueno y lo malo, pero preguntando por lo válido o lo conveniente ante las posibilidades concretas; de ese modo convierte a los actores en personajes de historias ubicadas en mundos en conflicto, cobijados por una ética particular basada en premisas singulares, lejos de las generalizaciones de la ética patriarcal.

Como lo han hecho algunos escritores hombres, ellas, las cronistas que abordamos, han integrado a su propuesta narrativa el testimonio de las víctimas, de los sobrevivientes, de los victimarios, de todos los actores armados; pero, -sin duda-, han logrado incorporar con mayor énfasis lo que evidencia el drama de quienes han recibido el impacto de la guerra en su misma piel, Lara nos ilustra:

La mayoría de las que ingresaban a las Farc lo hacían para huir del maltrato familiar, de la persecución, y del exceso de trabajo que les ponían en casa. Algunas los hacían también porque les atraía un guerrillero o les llamaba la atención el poder que generaban las armas. Los hombres en cambio se metían a la guerrilla, más porque 
a ellos sí les gustaban las armas y porque la vida no les ofrecía más oportunidades. En las Farc solo conocí a una sindicalista que estaba realmente convencida de la causa. Las demás éramos campesinas que creíamos haber encontrado una solución para nuestras vidas. (Lara, 2014, p.65)

Porque es precisamente el tono del lenguaje, la palabra, una distinción básica entre la escritura femenina y masculina; según Ciplijauskaité (1988), el ego masculino emerge con más fuerza que el subconsciente femenino; y así las mujeres buscan, escudriñan más en los sueños y los recuerdos, evocan; es por esto que a través de estas historias que resaltan la identidad femenina, se logra también un proceso de liberación y de reinterpretación de acontecimientos, lo que se traduce además, en un proceso de reparación y elaboración de los duelos. Es precisamente sobre ese lado esencial, sobre lo humano, sobre el sujeto que siente y padece el dolor, lo que las crónicas escritas por estas mujeres en las últimas dos décadas han empezado a desvelar con mayor ímpetusi se quiere- cuando narran las guerras y los conflictos modernos, pero desde una perspectiva de género que evidencia cómo las relaciones entre hombres y mujeres se han insertado en un molde patriarcal que impacta los cuerpos, reproduce las desigualdades y genera nuevas violencias.

Aunque enla tradición patriarcal cronística son más conocidos o han sido más difundidos los trabajos de un Mauricio Gómez, Germán Castro Caycedo, Alfredo Molano, Alonso Salazar, Juan Miguel Álvarez, Juan José Hoyos, Alberto Salcedo, -entre otros-, hoy está claro que, las mujeres cronistas en Colombia han hecho un trabajo importante, nutrido de una ardua y temeraria labor investigativa. En tono femenino, Patricia Nieto con Llanto en el paraíso. Crónicas de la guerra en Colombia (2008) o Los Escogidos, (2012); Patricia Lara con Las mujeres en la guerra (2014), Juanita León con No somos machos pero somos muchos (2004) y País de plomo (2005), le han apostado también a esa función de la denuncia, han narrado -cada una a su manera-, los avatares del 
conflicto destacando esos rostros y cuerpos olvidados, hombres o mujeres a los que las historias oficiales nunca les dio la palabra, pero ellas los han mostrado en otras facetas; desnudándolos para señalar esas marcas indelebles del horror.

En esa perspectiva, decimos que las crónicas de estas escritoras asumen características, muy propias de las narrativas femeninas contemporáneas, que insisten en salirse de los moldes tradicionales, y que Biruté Ciplijauskaité denomina subversión. Lo que ocurre en las estructuras sociales, dice, hace mímesis en las formas literarias, modelos, estilos, temas:

El procedimiento más común y más ampliamente usado en la novela escrita por mujeres que conscientemente quieren crear un discurso diferente femenino es la subversión. A medida que cambian las estructuras sociales se hace más evidente la necesidad de reflejarlas o incluso anticiparlas en la escritura. (Ciplijauskaité, 1988, p.205)

La subversión comienza desde adentro de los sujetos que participan en los hechos objeto de la crónica, pues pretende abarcar mucho más que los hechos objetivos y su enunciación ya no se circunscribe a parámetros racionales, alude al despliegue de las subjetividades femeninas que emergen con fuerza y, en momentos de coyuntura, para desenmascarar los tradicionales relatos oficiales.

El yo de estas narraciones corresponde al yo de mujeres que se visibilizan en el compromiso con otros y que en general toman posición en razón a los sentimientos. Las identidades femeninas aparecen con fuerza, incluso con la temeridad que implica atreverse a narrar y desvelar lo que entraña para los invisibilizados y oprimidos la guerra y el conflicto; las voces, los testimonios y las narrativas de las guerreras y de las víctimas, de las actoras y las testimoniantes las convierten en las protagonistas de una guerra que históricamente ha estado masculinizada; desmasculinizarla, implicaría que la crónica femenina se moviera a contracorriente de 
lo que se propone en la crónica tradicional como enfrentamiento excluyente de las fuerzas del bien contra el mal, donde el yo propuesto como narrador es el mismo sujeto viril y autónomo de la filosofía occidental.

De manera que la categoría de lo antiépico podría ayudarnos a apartarnos del esquema y mirar de otro modo las problemáticas sociales, en cuanto la marca subjetiva femenina narra de manera menos ideológica los acontecimientos y llama la atención sobre otros hechos y otros conflictos al interior del gran relato, como por ejemplo las exclusiones que sufren las mujeres sin importar si son víctimas o victimarias. De esta manera el recurso a la intimidad y los lenguajes afectivos que le son propios, lo personal, la experiencia de lo que una mujer hace cuando resiste o combate, le dan a la crónica femenina un distintivo especial, como lo señala Ciplijauskaité (1988, p. 17):

El recurso de primera persona sirve como el modo más apropiado para la indagación psicológica. Lo que se propone como el discurso -liberado-, cumple dos propósitos: expresa la reacción a la represión social de los tiempos pasados y lleva hacia el autoconocimiento:

Mientras ella hablaba surgían las imágenes y me producían una gran alegría. Me sentía fuerte de todo lo que no he vivido. Llegaba a mi casa y les decía: "Saben, algo está naciendo en mí, algo nuevo que antes no existía", pero no contestaban nada. Yo les quería decir: Tengo cada vez más fuerza, estoy creciendo ahora sí, voy a ser una mujer". Lo que crecía o a lo mejor estaba allí desde hace años era el ser mexicana, el hacerme mexicana; sentir que México estaba dentro de mí y que era el mismo que el de la Jesussa y que con solo abrir la rendija entraría. (Poniatowska, 2018 p.19)

En efecto, desde el siglo XIX, la escritura femenina es una especie de liberación que como lo señala Ciplijauskaité (1988), enfrenta la injusticia. La escritura es el camino que empieza a determinar la emancipación; porque la escritura constituyó 
una recompensa al encarcelamiento del cuerpo, por ello, en las crónicas vemos como la mujer polemiza, se declara en rebeldía, permite que emerja su yo interior:

Soy una mujer que llora, soy una mujer espíritu, soy una mujer que grita. Soy la mujer luna, soy la mujer intérprete, soy la mujer estrella, soy la mujer cielo, soy conocida en el cielo. Dios me conoce; todavía hay santos. Oye, luna, oye, mujer cruz del sur; oye, estrella de la mañana. Ven. ¿Cómo podremos descansar? Estamos fatigadas y aún no llega el día. (María Sabina, citada por Poniatowska, 2018, p.49)

La escritora va descubriendo su propia identidad, la que la hace como las otras Adelitas, mujeres aguerridas, pero que hicieron su trabajo en total silencio, calladas, nunca dijeron nada, la voz de la cronista las sacó del anonimato, porque como lo señala Gómez Campos "A las mujeres no las guía ningún desafío, no necesitan librar ningún combate para encontrar el sentido" (2013.p. 162).

Vemos entonces que las crónicas escritas por estas mujeres, han aportado al desvelamiento de otras realidades, con otros tonos y con otras maneras de narrar. Por ejemplo, el cambio de modo objetivo a subjetivo, así como la evidente insistencia en escribir con el cuerpo y las emociones, tal como lo describe Biruté Ciplijauskaité cuando afirma que "la nota personal se consigue a través de los sentidos más que del intelecto“, (1988, p.206). Y tal como también lo enuncia Gómez Campos (2013), los relatos femeninos dan cuenta de

una perspectiva más equilibrada con el componente autorreflexivo de un cuerpo de mujer, a diferencia del hombre a quien se prueba por su resistencia al poder físico, a la mujer se le prueba en su resistencia al dolor psíquico, esto es, en su capacidad de resistirse al dolor de los otros y no caer en la compasión. (p.162)

De igual modo, podemos afirmar que las cronistas han buscado también encontrar su propia voz; aquella que define a la 
mujer desde su intimidad, su reflexividad, como en una suerte de elaboración de un monólogo interior. Al respecto Nieto plantea:

Escribí Llanto en el paraíso como un acto de amor. Eso fue lo que siguió al silencio de hielo que me produjo la vista del paso del horror por Machuca. Tal vez lo que debo testimoniar es que la reinvención de mi oficio como cronista comenzó el 20 de octubre de 1998, cuando no pude reaccionar frente al evento que me proponía registrar. Tal vez quería escuchar a los sufrientes pero entonces no conocía los mecanismos interiores de ese acto. Casi diez años tardé en reinventar, a fuego lento, métodos de trabajo de campo y de escritura que no sorprenden a nadie. (Nieto, 2013, p.163)

En efecto, hay que reinventarse, como bien lo dice Nieto, a través de unas narrativas que ofrezcan una nueva lectura sobre lo sucedido, más consciente, más real, más humana. Quizás de eso se trate, de la necesidad de rechazar todos esos lenguajes y discursos heredados, para dar paso hacia la realidad psicológica, lenguajes más libres, donde lo oral y la espontaneidad se conjuguen y se introduzcan en la escritura a través del uso de la primera persona, porque en la mujer la palabra es una extensión de ella misma. Mientras que el hombre tiende a objetivar y establecer puentes entre mundos nuevos, ella observa, interpreta y actúa desde su conciencia y subjetividad. Así se aprecia también en las crónicas de Patricia Lara, Las mujeres en la guerra, (2014), donde la autora revela, a través de un lenguaje más del cuerpo y las emociones y de un relato en primera persona, las posiciones ideológicas diversas de las mujeres que han vivido de frente la guerra.

En la cárcel descubrí que allá no van simplemente los malos. También van los buenos. La prisión me sirvió para conocer a Colombia: en el Buen Pastor había mujeres de todo el país. Y me sirvió también para aprender a valorar a la familia: cuando se está en la revolución uno no se acuerda del sufrimiento que puede causarle a la mamá. En la cárcel descubrí algo que me sorprendió: que los que no son revolucionarios también sienten, también son personas valiosas y también quieren construir un mejor país. (Lara, 2014, p.59) 
Y lo vemos también reflejado en la "Última flocerita nutabe" (2008) de Patricia Nieto, crónica que expone la vida de Carmen una mujer campesina, personaje principal quien, en primera persona presenta la historia familiar de cómo ella, su madre y toda su descendencia, son víctimas de desplazamiento forzado y desde Nohová, pasando por Orobajo, Toledo, hasta Llanos de Cuibá, viven su destierro y su desgracia, como víctimas de la violencia política y de la violencia económica. La narración en forma de relato autobiográfico le ofrece la posibilidad de seleccionar de su vida lo que considera más idóneo para demostrar cómo ella, mujer y madre, se levanta una y otra vez, ante el dolor y la violencia que le es infringida.

Recuerdo que cuando subimos a Nohavá, mi padrastro cogió un costal cafetero y en medio de ropa me metió; enseguida le puso una cabuya en la boca y se lo puso en los hombros...yo subí ahí dentro del costal. Imagínese que en el encuentro de las dos quebradas, del Marín y del Chochito, me descargó. Yo recuerdo la peña donde me bajó. Me dijo: " Mija, yo estoy cansado, déjeme descansar, tengo que limpiarme el sudor porque me voy a poner ciego", Él fue un hombre muy comprensivo. Él se casó con otra mujer al mi mamá dejarlo. Mi mamá no lo quería a él, ella se juntó con él, pienso yo, porque tenía una hija para darle de comer. (Nieto, 2008, p.64)

Son también profusas las pausas descriptivas, donde abundan las referencias a diferentes personajes con los que la protagonista se encuentra a lo largo de la vida, descripciones detalladas y minuciosas, como a la manera de pequeñas historias dentro de la gran historia. Asimismo, la memoria, los recuerdos y evocaciones, resaltan con la alusión a diferentes poblados y localidades, ubicadas en áreas rurales, muchas de ellas en las riveras de los ríos; es insistente y reiterativa la narradora en la crónica con las descripciones espaciales de esos lugares que le "toca habitar", lo que puede traducirse en un interés de la cronista por desvelar cómo el ambiente interviene en la formación de ese carácter $\tan$ fuerte que le sirve para sobreponerse frente a la adversidad. Siguiendo con Nieto encontramos: 
Cuando yo me conocí, me llevaban a Orobajo. Ahora está muy acabado, con esa violencia tan horrible que hubo, la gente se salió. Yo tuve tantas experiencias malucas allá, pero es bonito. Recuerdo que buscaba en mi mamá un apoyo, que me consolara tan siquiera, porque ella nunca me dio confianza para yo contarle. Yo esperé, yo quise, quise una madre que me demostrara que yo era su hija y pudiera confiar en ella. Yo no la tuve, pero la vida, la vida le da muchos golpes a uno, y el mico aprende a bailar a palo. A mí me duele mucho todo lo que pasó. Porque yo no había conocido un hombre, yo no sabía que era un hombre y ese día él me violó; de una me ensangró, me volvió nada. (Nieto, 2008, p. 83)

Recapitulamos: las crónicas de las escritoras referidas, constituyen una pieza clave para comprender desde otras miradas, esas historias del conflicto poco conocidas o visibilizadas y para comprender también, cómo emerge esa voz femenina, la de la autora o cronista y la de la testimoniante que como protagonista, como víctima vivió, vio o padeció la tragedia de la guerra y el conflicto; o, como actora del mismo, presta su voz para narrar su experiencia, quizás hacer su duelo, demostrando su resistencia ante el dolor, su fragilidad e incluso su temeridad. De manera que, estas crónicas para tiempos difíciles de guerras y conflagraciones, siguen siendo necesarias, toda vez que a través de ellas se denuncia, se aclaran los hechos, se llama la atención sobre problemáticas y se invita a la reflexión sobre fenómenos tan complejos de leer y digerir. Asimismo, las crónicas estudiadas, contribuyen al reconocimiento de la antiepicidad, como categoría que permite evidenciar y caracterizar las actuaciones de las mujeres valientes, que narración en primera persona, desvelan ese yo protagónico que procura expresar la vida entera a través de un discurso, que actualiza el viejo lema existencialista: "Yo soy yo y mis circunstancias", mediante el entrecruzamiento de la conciencia y el curso de los acontecimientos. En el devenir fáctico de cada persona el vínculo está presente de manera permanente, pero el relato de la historia tiende a considerar ambos aspectos de manera independiente. Le corresponde a la escritora de crónicas 
reconfigurar las técnicas de la escritura de modo que el relato de las experiencias humanas legitime la subjetividad como forma de acercamiento a lo real. 


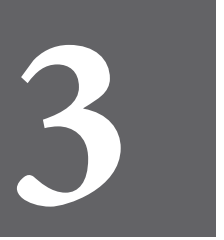

CAPÍTULO TRES 



\section{Conclusiones}

Durante el presente trabajo hemos examinado textos narrativos de autoras latinoamericanas, buscando las marcas particulares de su escritura con el fin de ponerlas en relación con las problemáticas de las identidades femeninas. Creemos que hemos logrado agrupar y clasificar varios de los procedimientos usados por las autoras, además de interpretar dentro de un sistema coherente recursos particulares de narradoras particulares para sistematizar los alcances y la estabilidad semántica de la categoría de antiepicidad que se despliega en el análisis. Sin embargo, todo esto puede ser revisado, precisado o ampliado por futuros investigadores. La noción de identidad femenina es polémica y estamos de acuerdo que debe ser una noción plural, de hecho al asumirla de este modo hemos encontrado varias cosas:

- Efectivamente, el modo de ser de la cultura con su vocación racional que ordena el mundo como una colección de objetos sobre los que se opera con dispositivos cuantificables, ha terminado por reducir el pensamiento a un sistema de clasificaciones en potentes dualidades asimétricas. Sólo que muy pronto se revela que el sistema dual no puede cubrir la multiplicidad de lo existente. El caso de masculino/femenino es insuficiente para cubrir el abanico de opciones posibles en cuanto a género y entonces, hombre y 
mujer terminan por existir según las cualidades de cada uno de los elementos del par dual, pues la pareja formal de términos precede a la existencia. Además de esta concepción paradigmática, existen concepciones más incluyentes y mucho más apropiadas para referirse a los mundos humanos. Una de ellas es la de Jerome Bruner cuando dice que: "Para interiorizar la experiencia, los seres humanos usan dos modalidades de pensamiento, bien diferenciadas en sus estructuras de operación y alcance cognitivo: la paradigmática y la narrativa" (1998, p.23). Puesto que también la narración se constituye, al igual quela categorización, en otra forma de entender la realidad y de dar significado a los acontecimientos, resulta útil examinar narraciones con el fin de encontrar en ellas nexos entre el pensamiento narrativo y el mundo real. La narrativa se acerca a un modo de conexión particular entre los sucesos, un acercamiento subjetivo a los hechos y un sentirse implicado en ellos, al punto de parecer como si la existencia del hecho estuviese condicionada por la necesidad de un sujeto que al testificar los hechos ponga en juego su sensibilidad y la agudeza de su juicio al mismo tiempo.

- Preguntarse por la existencia de una literatura femenina tiene sentido porque creemos que lo femenino terminó por nombrar un conjunto de actitudes, prácticas, lenguajes y creencias que fueron marca para el conjunto de las mujeres a lo largo de muchos siglos. Pero, si bien las mujeres y el universo de lo femenino parecieron acoplarse bien en torno algunos aspectos de la vida privada hoy se revela como impostura cultural que requiere la modificación de las prácticas cognitivas, discursivas y comunicativas de los seres humanos en torno a este problema. La Literatura Femenina configura un cuerpo de obras que decanta léxicos, sintaxis y significados propios de la experiencia de ser mujer en un universo patriarcal.

- Interrogar la construcción de temas y personajes, detenerse en los recursos lingüísticos, permite interpretar las narraciones como "relación entre los personajes y sus acciones, el conflicto 
que los convoca, y el grado de conciencia o valoración que cada personaje asume sobre ese conflicto" (Bruner, 1998, p.32). Basadas en esta premisa, leer las obras de las autoras elegidas nos permite proponer la existencia de una literatura femenina dada la particularidad de los comportamientos verbales y los lenguajes disponibles para las mujeres desde la formación de las estructuras patriarcales, puesto que la experiencia femenina del mundo al igual que la experiencia narrativa también se construye en el tránsito entre la conciencia sobre los hechos concretos y los hechos encadenados en forma de trama.

- Propp (1998) encontró unas funciones fijas en el relato que incluyen la progresión desde una desacomodación inicial hasta el triunfo final del protagonista. Incluye el combate antagónico contra un oponente. Incluye la transgresión de algún principio por cuya causa la narración aparece como el cumplimiento de un destino. A estos rasgos, en nuestra investigación los denominamos rasgos de epicidad porque, aunque aparentemente las novelas acompañan el desenvolvimiento de la iniciativa individual, ellas también han institucionalizado la arquitectura del relato y han contribuido a la construcción de los arquetipos culturales. En oposición a ellas construimos la categoría de antiepicidad como una forma de leer narraciones en las que priman el recurso a la primera persona y los protagonistas femeninos; la construcción del yo narrativo como respuesta a la situación y la existencia de otros personajes que lo limitan y cuestionan; el proyecto de vida o destino de la protagonista como un no destino, dentro de reglas excluyentes que detienen su impulso creador; una perspectiva subjetiva del narrador que tiende a implicarse en los acontecimientos narrados de manera personal; referentes de tiempo y espacios para la expresión de la subjetividad, como los espacios cerrados o los tiempos circulares y la concentración en la transformación interior; lenguajes coloquiales, enunciados pragmáticos, párrafos rítmicos y musicales; subversión de los estereotipos, sobre todo los femeninos; construcción de la identidad de cara a los modelos generacionales; proceso de concienciación del significado de ser 
mujer que incluye la contradicción, los silencios y las ambigüedades como parte normal de la existencia; tono de denuncia frente a la represión y la exclusión del mundo patriarcal.

Cuando se interrogan las narraciones y las actuaciones de los personajes, la atención a los aspectos acabados de enumerar puede arrojar claves sobre el proyecto de existencia de las mujeres dentro del universo patriarcal, pues cada historia que leemos debe ser asimilada más allá de sus secuencias y anécdotas como la postulación de un hecho relevante dentro del conjunto de historias que soporta el modo de ser de la cultura. Por eso, cuando interrogamos narraciones escritas por mujeres, negros, indígenas, intersexuales los personajes y las tramas podrán darnos visiones alternativas al proyecto patriarcal, pues ellos han sido excluidos como hablantes legítimos dentro del modelo cultural. Además de las autoras analizadas en el cuerpo del texto, encontramos que muchas otras autoras contemporáneas pueden ser leídas a la luz de la antiepicidad como categoría. Veamos algunas de ellas:

1. Sangre en el ojo de Lina Meruane, donde la protagonista es una emigrante latinoamericana, profesional, adinerada trabaja en una urbe del primer mundo, pero en el momento de estar enferma (episodio autobiográfico) y quedarse ciega vuela a su Chile natal y sólo desde allá logra recomponer su vida amorosa y las relaciones con sus padres que han estado marcadas por una excesiva lejanía y formalismo. La obligación de ayudarse entre los miembros de la familia ha cedido paso a un intercambio de favores que en lo posible se evita porque dejan en deuda al receptor del favor. Hay un lazo artificial que sólo la ceguera-anulación del punto de vistapermite matizar desde el afecto. Aunque existe una conciencia de la autora de la inutilidad del lazo del afecto para vivir la vida moderna que se construye alrededor de patrones más racionales, al final vuelve a sus padres, a su familia como necesidad vital de reconocimiento. En otros de sus textos, como Volverse palestina, Lina Meruane plantea una revaloración de la familia y el nexo con las historias donde los parientes van apareciendo como creadores 
de un mundo para sus descendientes mientras el relato de sus acciones y el conocimiento más íntimo de sus prácticas y creencias pueda tocar a esos herederos.

2. La perra de Pilar Quintana. Una novela en la que Damaris, una mujer negra y pobre habitante de una isla en el pacífico vive una cotidianidad aparentemente tranquila, pero llena de carencias afectivas. Con 39 años de edad, renuncia a seguir intentando quedar embarazada. Las relaciones de la mujer con la maternidad, el no llegar a poder realizar su feminidad como madre hace que desplace su afecto hacia una perrita huérfana que no podría sobrevivir sin su cuidado. La perra es metáfora de ella misma o de sus hijos no natos puesto que la pequeñez y la insignificancia los definen en el conjunto de lo existente. La novela recorre distintos momentos del afecto a través de la relación entre la mujer y la perra incluido el momento del desamor. Una mujer que no puede llegar a ser madre, es como una planta que se seca sin haber florecido. No es nada y esta imposición de la maternidad convierte la vida de Damaris en una lucha sin esperanza de triunfo, sin oportunidad de realización, enfrentada al no destino, pues socialmente la realización de la mujer incluye la maternidad como su aspecto principal.

3. Dulce compañía de Laura Restrepo, cuenta como una reportera bogotana, la Mona, viaja hasta Galilea, un barrio de la periferia para investigar la aparición de un ángel. Al comienzo toma distancia de su relato, pero poco a poco la historia le va revelando su sentido en la medida en que ella asume las tareas de la investigación como una forma de vivir la historia y tomar parte en ella. Desde el punto de vista elegido para informar, no existe la objetividad. Cuando busca el primer contacto con el ángel a través del niño Orlando, encargado por la junta que administra la logística de la aparición, de acompañar la investigación de la Mona, ella abandona sus ideas de citadina y empieza a identificarse con los personajes comprometidos con el mundo del angélico, desde la madre de la criatura, Ara hasta Baby Killer, boxeadora 
guardaespaldas del ser angélico. Desde su arribo, la Mona es escogida por la Junta como la novia elegida y madre de sus hijos, lo que efectivamente sucede al final de la historia. De esta historia es interesante destacar como la Mona puede transitar desde su propio mundo al mundo de los otros y la forma como los hechos van cobrando significado en la medida en que la afectan vitalmente. El conflicto del padre Benito, católico con la aparición del ángel pasa de ser un conflicto metafísico sobre la superstición y la fe para convertirse en un problema de amante celoso y despechado. Los asuntos que podrían ser objetivos se tratan desde la subjetividad y así si hay oposición lógica entre fe y ciencia este no se resuelve mediante argumentaciones, sino mediante los sentimientos que la autora asigna a sus personajes. El vaticinio, la premonición y la intuición se validan en esta novela como forma de conocimiento que contribuye a responder quién es el que siente, en este caso, ayudan a saber qué clase de mujer es la Mona y hasta dónde cuenta con la fuerza de sus convicciones.

4. Mayra Santos-Febres publicó en 2015 una novela titulada La amante de Gardel. A través de la narración de un romance desafortunado entre Carlos Gardel y la protagonista de la historia Micaela Thorné, se exponen aspectos de la condición de las mujeres en muchos países caribeños. Micaela es nieta de Mano Santa una anciana curandera muy famosa en la isla de Puerto Rico, por cuyas dotes de médica poderosa que conoce la cura de enfermedades, las venéreas entre otras, Micaela conoce a Gardel. La chica quiere ser médica y es protegida de una doctora también famosa como Mano Santa, pero en otro sentido, Martha Roberts profesora de la facultad de medicina. A través de la historia personal de la chica, su capacidad para moverse en los dos mundos, el de la magia y el de la ciencia, se muestra una forma de construcción de la identidad que no repara en oposiciones lógicas. Sólo repara en su vocación de cuidado para sanar a otros. Ella lo descubrió, cuando le ayudó a su abuela a sacar al cantante argentino de su inconsciencia y de su fiebre usando no sólo las plantas sino el aliento, el calor corporal, la capacidad de asimilación del dolor ajeno para que la cura fuera 
posible. La sensibilidad especial de Micaela, la sabiduría de su cuerpo, las virtudes de su ser mujer compasiva la acompañan en su tarea. Al final, la muerte de Mano Santa así como la dureza de la vida en la ciudad, al lado de un Gardel que la usa antes que amarla la convierten en una persona escéptica, que se compromete con la medicina, pero un poco al modo occidental. Micaela toma la decisión de hacerse doctora y profesora universitaria dejando de lado el saber ancestral representado por los conocimientos herbolarios de Mano Santa, pero en verdad su búsqueda es la de potenciar, por medios industriales, el poder de una planta capaz de cambiar el destino de las mujeres, pues infertiliza los vientres y cura las enfermedades del amor. En esta novela el cuerpo y sus afecciones, al igual que el afecto y la emoción se presentan como única ruta para dar sentido a la existencia, como cuando toma la decisión de negarle la cura a Gardel para que su garganta no vuelva a inflamarse nunca. $O$ cuando pregunta “ $¿ Q$ ué es ser mujer en estos tiempos: un juego con la muerte, un eco que resuena en la distancia?"

5. El oído miope de Adriana Villegas narra la vida de una joven abogada, colombiana en Nueva York, Cristina Mejía, quien realiza trabajos de limpieza para ganarse la vida. Cada capítulo con el nombre de un día de la semana se va encadenando con otros capítulos para detallar de manera repetida las faenas de limpieza aquí y allí, según la condición de la persona contratante de sus servicios. La repetición de escenas muestra la alienación de la existencia en esa interminable serie de días iguales. No hay un proyecto de vida, sólo amontonamiento de acciones rutinarias. Las únicas escapadas se producen a través de la lectura y el aprendizaje del léxico de la lengua inglesa. Sólo que son muy breves y al parecer simplemente anecdóticas. De manera llamativa los hombres están ausentes en la novela y los pocos personajes femeninos aparecen como voces al otro lado del correo o de la llamada telefónica. También el espacio vital es mínimo. Un camarote que le alquilan en una casa de familia y su maleta debajo de la cama. Toda la 
historia crea el clima de asfixia que al parecer quiere decir que no importa a dónde escape, una mujer siempre vivirá al margen de una vida plena.

6. Adelaida Fernández también se suma a las anteriores autoras, esta vez desde el lenguaje en su novela Afuera crece un mundo. La historia es poética en sí misma, pues trata de reconstruir una vida para los personajes negros cuyo protagonismo es apenas tangencial en la novela de Jorge Isaacs, María. Da voz a estos seres que ni en la literatura ni en la historia de su esclavitud la tuvieron, porque quiere dotarlos de una humanidad sensible, solidaria y llena de los mismos afanes que la de los blancos hacendados de El Paraíso.

Tampoco alcanza a saber que es oficio del niño Efraím retar el peligro, los desmayos lo aburren, flores, encajes, grajos inofensivos le menoscaban los reflejos varoniles, de manera que se va detrás del tigre. Cántame en esa lengua pagana que tú sabes. ¿No dice cosas malas? Dice cosas de agua, ¿no la oye como corre? ¿Me voy a morir? Los ángeles no se mueren. Sonríe. Ella no sabe que los ángeles no son de este mundo y que a ella le despuntan unas alas muy diferentes de la esperanza. (Fernández, 2017, p. 82)

Este diálogo de Feliciana, una de las narradoras, con María, la protagonista de la novela de Isaacs es una muestra de la delicadeza del lenguaje de Fernández: su musicalidad, el uso de una sintaxis de frases breves, la incorporación de sugestiones animistas y mágicas son el recurso elegido para hablar de los matices profundos que estuvieron presentes en la gesta libertaria de los negros americanos. La subjetividad presente en el relato, antes que de grandes acontecimientos y batallas, habla de una sensibilidad especial, como aquello que merece ser contado. Las relaciones de familia, el amor de los amantes, pero sobre todo el amor filial y el amor maternal construyen el tema objetivo de la libertad en un recorrido por la nostalgia y la necesidad de regresar al lugar de origen para encontrar a los seres queridos que ya no es posible volver a ver. 
Las seis novelas reseñadas de manera rápida en este apartado, apuntan no sólo al hecho de ser escritas por mujeres, sino a rescatar la conciencia del cuerpo. Destacamos el hecho por varias razones:

a. Por cuanto propuestas éticas en la filosofía moderna nacen de la conciencia de la vulnerabilidad y la dependencia originadas en nuestra identidad animal y nuestra corporalidad (Alasdair MacIntyre). De aquí sale un componente ético del proyecto femenino de humanidad.

b. La estética problematiza el concepto de corporalidad, expresiones artísticas a través del cuerpo, técnicas de creación a partir de la memoria como rasgo corporal, así como estrategias de recepción usando el cuerpo y haciendo de la experiencia artística una experiencia viva.

c. Hoy, la construcción de significados culturales pasa a través del registro de imágenes visoespaciales provenientes de las pantallas, cuyos mensajes son dirigidos básicamente a la sensibilidad.

Estas instancias éticas, estéticas y cognitivas pueden ser exploradas y asimiladas por mujeres con gran propiedad dada la clase de experiencia femenina del mundo.

Una vez establecidos los hechos anteriores, debemos encontrar los rasgos de feminidad que harán parte del proyecto de humanidad que las mujeres pueden proyectar desde su experiencia. Así como lenguajes que puedan enriquecer dicho proyecto. Debemos encontrar cómo los personajes femeninos construidos por mujeres pueden darnos respuestas a las preguntas por la feminidad. Sabemos que no tenemos muchas respuestas todavía, pero creemos que tenemos un camino y es el de relacionar las posturas femeninas ante los eventos del mundo como una postura ética, y la literatura femenina en cuanto permite postular esa ética como una forma de humanismo alternativa al humanismo patriarcal. De él haría parte la afectividad como criterio de decisión de modo que se puedan enriquecer nuestros 
criterios actuales de utilidad, racionalidad o conveniencia. De un primer listado harían parte los siguientes elementos

- La comprensión de la actividad literaria como una forma de vida antes que como ejercicio intelectual.

- Elevar la escritura de los ambientes y sucesos cotidianos a un tema como tal, lo que implica la deconstrucción de las categorías del relato tales como, primero, las referencias objetivas de tiempo y espacio, en favor de formas relacionadas con la subjetividad y la experiencia; $y$, segundo, la distancia entre narrador y protagonista hasta conseguir una conciencia del narrador capaz de inmiscuirse de manera personal en los asuntos del protagonista.

- Estrategias discursivas para vincular lenguaje e identidad.

- Deconstrucción de estereotipos femeninos como motivo de la narración.

- Aparición de un fondo de significados en relación con la emoción y el erotismo capaces de vincular cuerpo y decisión, más allá del mecanismo argumento-decisión.

Por eso, compartimos la idea de Rubí de María Gómez acerca de que las mujeres tienen un proyecto de humanidad diferente del proyecto patriarcal, puesto que existe una visión femenina de mundo que incluye preguntas por el afuera, los eventos del mundo, pero principalmente por el yo, por el otro, por el actuar ético y el valor de la sensibilidad dentro de la ética. La antiepicidad como característica de los relatos analizados para este trabajo, puede ser una categoría útil para comprender ese proyecto de humanismo como una salida cultural al hecho de que por un lado, el patriarcado haya magnificado de manera tan fundamental las diferencias biológicas entre el hombre y la mujer y por otro lado, haya hecho coincidir el arquetipo de humanidad con la figura viril. 


\section{Bibliografía}

Abad, H. (2007) El olvido que seremos. Barcelona: Seix Barral.

Andruetto, M. T. (2005), Veladuras. Argentina: Norma.

Andruetto, M. T. (2013), Lengua madre. Bogotá: Babel libros.

Ángel, A. L. (1982), Misiá señora. Barcelona, Argos Vergara

Arizmendi, M \& Arbona, G. (eds). (2008). Letra de mujer. España: Laberinto.

Benjamin, W. (1991) El narrador. Trad. Roberto Blatt 1991. Madrid. Taurus.

Bollmann, S, (2015) Mujeres y libros, una pasión con consecuencias. Barcelona: Seix Barral.

Brandon, R (2005). Hacerlo explícito, España, Balmes. 
Bruner, J. (2013). La fábrica de historias, Fondo de Cultura Económica.

Bruner, J. (1998). Actos de significado. Madrid: Alianza.

Ciplijauskaité, B. (1988). La novela femenina contemporánea (1970-1985): hacia una tipología de la narración en primera persona (Vol. 3). Barcelona: Anthropos.

Cixous, H. (1979). La risa de la medusa. Ensayos sobre la escritura. Barcelona: Anthropos.

Correa, C. (2011). La Crónica reina sin corona. Periodismo y Literatura. Fecundaciones mutuas. Medellín: Fondo Editorial. Universidad EAFIT.

De Certeau, M. (2000). La invención de lo cotidiano. México, Instituto Tecnológico y de Estudios Superiores de Occidente, A.C.

Egan, L. (2008). Carlos Monsivais. Cultura y crónica en el México contemporáneo, México, Fondo de Cultura Económica.

Fernández, A. (2017). Afuera crece un mundo. Bogotá, Seix Barral.

Foucault, M. (1990). Tecnologías del yo. Madrid, Espasa.

García-Berrio, A. y Huerta-Calvo, J. H. (1992). Los géneros literarios: sistema e historia. Madrid: Cátedra.

Garza, N. (2007). El ensayo como una poética del pensamiento. Rev. Andamios.,10(7), 271-287.

Gómez Campos, R D.M. (2013) El feminismo es un humanismo. Barcelona: Anthropos. 
Guerra, W. (2006). Todos se van. Barcelona, Anagrama.

Heidegger, M. (1998), Caminos del bosque. Madrid: Alianza.

Lara, P. (2014). Las mujeres en la guerra. Bogotá: Planeta.

León, J. (2004). No somos machos pero somos muchos. Bogotá: Norma.

MacIntyre, A. (1999), Animales racionales y dependientes. Por qué los seres humanos necesitamos las virtudes. Barcelona: Paidós.

MacIntyre, A. (2001), Tras la virtud. Barcelona: Crítica.

Meruane, L. (2017), Sangre en el ojo. Bogotá, Random House.

Molano, A. (2016). A lomo de mula. Viajes al corazón de las Farc. Bogotá: Aguilar.

Montoya, L. (1939), La aventura misional de Dabeiba. Bogotá, Ediciones paulinas.

Montoya, L. (1971). Autobiografía. Medellín, Carvajal.

Nieto, P. (2012). Los escogidos. Medellín. Universidad de Antioquia.

Nieto, P. (2008). Llanto en el paraíso. Medellín: Universidad de Antioquia.

Nieto, P. (2013). "Relatos autobiográficos del conflicto armado en Colombia. El caso reciente de la ciudad de Medellín". Tesis doctoral. Universidad Nacional de la Plata.

Nussbaum, M. (1999), Justicia poética, Barcelona, Andrés Bello. 
Nussbaum, M. (2002), Las mujeres y el desarrollo humano, Barcelona, Herder.

Ong, W. (1999). Oralidad y escritura. México: Fondo de Cultura Económica.

Oviedo, J. (2012). Crónica de los años sesenta. España: Letras libres.

Piglia, R. (1993), Respiración artificial, Bogotá. Tercer Mundo.

Poniatowska, E. (2018). Las indómitas, México. Seix Barral.

Poniatowska, E. (2001). La noche de Tlatelolco. México. Era.

Quintana, P. (2017). La perra. Bogotá, Penguin Random House.

Reguillo, R. (2000). Textos fronterizos. La crónica una escritura a la intemperie. México: Diálogos.

Restrepo, L. (1995) Dulce compañía. Bogotá, Norma.

Ricoeur, P. (1996), Sí mismo como otro, México, Siglo XXI.

Rotker, S. (2005). La invención de la crónica. México: Fondo de Cultura Económica.

Sáez, B. (2014). Cuerpo, memoria y representación: Adriana Cavarero y Judith Butler en diálogo. Barcelona, Icaria.

Santos-Febres, M. (2015). La amante de Gardel. México, Planeta.

Suárez Gómez, J. E. (2011) La Literatura Testimonial como representación de pasados violentos en México y Colombia: Siguiendo el corte y "Guerra en el paraíso". Revista de Ciencias Sociales de la Universidad de Latinoamérica. V.1 No.11. Enero junio de 2011, pp.57-82. 
Trías, F. (2015), La azotea. Bogotá, Laguna libros.

Vallejo, M. (1997). La crónica en Colombia. Bogotá: Planeta.

Villegas, A. (2018). El oído miope. Bogotá, Alfaguara.

Villoro, J. (2012). La crónica, ornitorrinco de la prosa. En D. Jaramillo (ed.), Antología de crónica latinoamericana actual (pp. 577-582). Madrid: Alfaguara.

Woolf, V. (1981) Las mujeres y la literatura. Barcelona, Lumen.

Woolf, V. (1986), Una habitación propia. Barcelona, Seix Barral.

Woolf, V. (1999), Tres guineas. Barcelona, Lumen. 



\section{Anexos}

\section{Anexo 1. Entrevista a María Teresa Andruetto \\ Por Susana Henao Montoya \\ Transcripción: Consuelo Chica}

Entrevistadora: María Teresa esta es una entrevista informal, motivada en el deseo de hablar, de escuchar las opiniones de una autora sobre un tema específico, pero también un poquito sobre su propia obra, sobre usted como escritora. Entonces la primera pregunta es, ¿Cuándo usted escribe lo hace como una necesidad de resolver un asunto íntimo, dar respuesta a una emoción, por ejemplo, o usted tiene proyectos formales como decir el mundo necesita oír esto y yo voy a decirlo?

Entrevistada: Sin duda lo primero, más que una necesidad de resolver algo íntimo, es un deseo que aparece, como una necesidad frente a algo que veo o escucho o reaparece en mi memoria, o sea, nunca es un proyecto, nunca me ha funcionado la escritura así, como un proyecto. ¿Yo tendría que hablar sobre tales asuntos, 
tales temas? No, es algo interno; lo que pasa es que en eso interno, que sería mi propio ser, ciertas cuestiones del mundo persisten en aparecer, porque por mi extracción de clase, por mi recorrido de vida, por mi compromiso social como persona, porque he conocido distintos contextos, entonces he conocido personas de diversas características; por la historia de las mujeres en mi familia, por una cantidad de cosas, por mi condición, porque soy una mujer que en algún momento estuvo separada y crió su hija como jefa de hogar, después yo hice otra pareja, pero digamos, por todo eso, hay ciertos asuntos de lo social que se engarzan muy fuertemente con mi deseo, entonces, aparece como de un modo natural, no porque yo me los plantee, pero enseguida aparece.

Entrevistadora: Creo que ese sería un proceder muy propio de las mujeres, ¿cierto?, sentir ese llamado.

Entrevistada: $\mathrm{Si}$, no es una escritura racional, no es un proyecto racional de escritura, en el sentido de que haya un plan que se siga, a rajatabla. No, hay un impulso que abre a una imagen $\mathrm{y}$ tras eso voy $\mathrm{y}$ algo aparece.

Entrevistadora: Sobre el asunto de los géneros literarios: mirando su biografía, usted ha trabajado todos los géneros: la novela, el cuento, el ensayo y hasta el teatro.

Entrevistada: Sí, incluso ahora estoy trabajando en una obra de teatro

Entrevistadora: ¿Cuál cree usted que es el género que mejor sienta a su escritura o para usted es como una aventura ir por todos ellos?

Entrevistada: Es distinto cada uno, es distinta mi vinculación con cada uno de los géneros y la historia sobre cómo he ido a parar a cada uno de ellos; hay algo que une a todos, que es que, para mí, digamos, una experiencia de lenguaje y entonces son formas mías 
de desafiar y desafiarme en relación con el lenguaje, con la lengua; me parece que el centro de mi deseo va hacia la narrativa y hacia la poesía, lo que pasa, es que la poesía es algo que aparece pocas veces. Ahora en noviembre pasado salió publicado mi último libro, se llama Cleofe pero el anterior había sido del 2008, o sea que pasaron 10 años entre la publicación de un libro de poemas y el otro. La poesía aparece en mí, aunque soy una ferviente lectora de poesía, la escritura de poesía aparece en mi muy ligada a cuestiones internas, emocionales muy fuertes que decantan de algún modo, por ejemplo, hay un libro, que revisa escenas de infancia, bajo el cual va un duelo muy sutil que probablemente el lector no lo vea por cierta melancolía que tiene que ver con pérdidas mías, muy personales. Este último tiene que ver con madres y la relación madre e hija; los poemas básicamente tienen que ver con los últimos años de mi madre, mis conversaciones con ella en un proceso de Alzheimer, de ella. Pero en ese tiempo también mi hija fue madre entonces, también me vinculé a otras madres. También la palabra madre en Argentina políticamente tiene una fuerza muy grande. Entonces el libro tiene que ver con eso.

La narrativa es más frecuente en mí, la escritura de cuentos o novelas, he escrito mucho, tanto, para adultos como para jóvenes o chicos, pero, no tengo mucha diferencia ahí, salvo con los libros para niños para esos primerísimos lectores he escrito menos, esos si los pondría como diferentes. Pero entre un libro para jóvenes, editado en una colección para jóvenes y una novela para adultos, no encuentro mucha diferencia en mi proceso de escritura. El ensayo también me gusta, la reflexión sobre la escritura, sobre la lengua sobre los lectores pero siempre los he escrito en relación a un trabajo o a un pedido: para un congreso, para alguna jornada o porque me han pedido que piense en alguna cuestión o un determinado tema. Y si entre alguno de mis intereses he escrito, es posible que tenga ensayos que he acumulado a lo largo de los años. Los he reunido en un par de libros. ¿Y el teatro? Es algo muy accesorio en mí, en el sentido de que he escrito generalmente 
convocada por grupos de teatro de mi ciudad, porque he sido muchos años profesora en una escuela de teatro para actores y profesores de teatro, entonces, en dos o tres ocasiones he escrito de esa manera, pero, ahora sin que nadie me lo pidiera apareció algo en lo que estoy trabajando, es un borrador de una potencial obra de teatro.

Entrevistadora: El teatro aparece como un nuevo generador de escritura, casi como un modelo sobre cómo hacer novela, me parece a mí. Tal vez sea por la rapidez que la narración alcanza a través del diálogo. Cree usted que la literatura reciente está muy volcada a la acción, con poca reflexión.

\section{Entrevistada: En mi caso no es tan claro}

Entrevistadora: Sí, tal vez porque somos de una generación para la que reflexión es parte importante de todo ese proceso

Entrevistada: Mi proceso de escritura tiene que ver con procesos de motivos altos, muy fuertes digamos que yo regulo para que no desborden y me interesa mucho esa contención, me interesa la intensidad de lo que se siente o se pueda hacer sentir al lector y la contención del lenguaje, para que ahí haya un equilibrio que no desborde, que no esté crudo. En el caso del teatro, por supuesto que también está ligado a la acción, yo escribí un borrador, porque es una obra donde dos varones son los protagonistas, algunos se visten de mujeres porque es una obra que sucede en una celda, entonces son presos de la dictadura de Argentina que están representando ahí una obra. Ellos la están haciendo con algo que recuerdan de afuera y todos los que tienen que actuar son presos varones, como hacen falta algunas mujeres en la obra, algunos se ponen una colcha. Le di el texto a un director, le pedí una lectura para que me diera una devolución, un director de teatro de mi ciudad que además es docente muy interesante y que tiene un grupo de actores varones exclusivamente, varones algunos como toscos, viejos, no actores como muchachitos 
bonitos sino con aspecto rudo. Me interesaba eso. Él lo leyó y le resultó muy interesante.

Entrevistadora: ¿Su premio Hans Christian Andersen, es por el conjunto de la obra, cierto? Pero usted podría tener una percepción sobre cuál es el libro que contribuye más a su relevancia como escritora, su nombre grande en Latinoamérica, ¿Cómo es eso?

Entrevistada: No sé. Stefano es un clásico y tal vez eso ayudó. Es una novela que edité en el 98, o sea que tiene 20 años y tiene publicaciones en Argentina, muchas revisiones; tiene una edición en Colombia, otra en México, en Brasil, en Eslovenia, en China, Corea, Turquía; tiene varias en Alemania. Italia, Galicia, muchos lugares, muchas lenguas. Digamos entonces probablemente es la obra por la que más se me reconoce. "La niña, el corazón y la casa" que es bastante posterior es una novela que también tiene una edición colombiana en Babel, es una novela que tiene unos 8 años de editada, un poco anterior a Andersen.

Entrevistadora: ¿Su libro preferido?

Entrevistada: Stefano. De todo lo que escribí, porque también tengo mis obras para adultos, yo diría, que Lengua madre. Es una novela de adultos editada acá en Colombia, hay una trilogía entre Stefano, una novela mía primera, que aquí no se encuentra que se llama Tama y Lengua madre, que es una novela muy leída como una novela del mundo de mujeres.

Entrevistadora: ¿Sus obras están en editoriales colombianas?

Entrevistada: Sí. Lengua madre está publicada acá. Lengua madre; son tres mujeres la abuela, la madre y la nieta. Está contada desde la perspectiva de la niñita, una mujer joven de unos 30 años, que vive, recibe una beca en el extranjero y vuelve para la muerte de su madre, o sea su madre ya ha muerto; la madre le ha pedido 
que mire unas cartas que hay en una caja bajo la cama. La madre vive en un lugar de la Patagonia Argentina, no la crió a ella porque cuando ella nació, nació en un sótano en tiempo de la dictadura, entonces bueno la sacaron de ahí. La crió la abuela entonces hay varias cosas ahí, es esa hija descubriendo un poco a su madre en las cartas que son en general cartas de la abuela a la madre descubriendo la disputa entre las dos por criarla, por tenerla digamos. Primero, hace falta que la crie la abuela pero cuando la dictadura termina la madre la quiere recuperar y bueno ahí descubre ella esa disputa. Está la dictadura como sombra porque la madre de la protagonista está escondida en un sótano durante esos años, el padre se ha ido al exilio, no se hace a cargo aunque tiene conexión, descubre ella que tiene conexión con su madre por las cartas, pero bueno ahí está el lugar de la mujer que se construye en función de la mujer otra, en función o en oposición a las otras mujeres de su historia y también está el tema de los hijos de los militantes de la dictadura porque la madre de esta protagonista sería alguien de mi edad, la que estuvo escondida y tuvo su hija en un sótano, y los hijos de esa generación a veces han reprochado a sus padres que en función de pensar en la sociedad no han pensado en los propios hijos. Entonces, está toda esa lucha entre tomar posición pública frente a la sociedad, digamos luchar por los derechos de un país por la condición de la sociedad o en replegarse en la casa con los niños, bueno toda esa tensión y a mí me parece que el camino de la nieta, de la mujer más joven es un camino de enojo y de aceptación y de reconciliación con su madre y con su abuela.

Entrevistadora: Y el título: ¿Lengua madre?, ¿Ella está cómo reconociendo las palabras de su mamá?

Entrevistada: Hay varias cosas en la lengua de la madre. La joven es alguien que está haciendo una investigación sobre el lenguaje de mujeres en Alemania con una beca y hace una investigación sobre la obra de Doris Lessing. Entonces la lengua de la madre, las cartas en particular que son a lo único que accede y a 
algunas cartas de la abuela, sobre todo en esa parte de la palabra, ese es el lenguaje en el que ella se inserta. Ese es el tema.

Entrevistadora: Sí, me encantaría leerla.

Entrevistada: Si, la tienes que leer porque, después hay otra novela que de algún modo se articula con esta. Es una misma chica buscando la historia de su padre en la oralidad de los relatos de las mujeres del noroeste argentino, el lugar donde vivía el padre, aunque tiene como la misma tónica, se llama los Manchados. En Lengua madre la materia son las cartas o sea ella accede al conocimiento de la madre, de la abuela a través de la palabra escrita de las cartas, en el caso del padre accede a través de los relatos de gente que lo conoció, entonces en uno está la palabra oral, en otro está la escrita, siempre es una mujer buscando sus raíces, las de la madre en Lengua madre y las del padre en los Manchados y a través de ese contexto que se ve la época, la situación y lo demás.

Entrevistadora: $¿$ Su compromiso es como doble, no? Por un lado, está eso que constituye lo femenino en el mundo, pero por otro está lo del compromiso político, ambas cosas a la vez.

Entrevistada: Lo privado y lo público, lo pequeño y lo grande, la idea de que lo privado también es político, lo individual también es político bueno todo eso está muy atravesado de por sí, pero Lengua madre me parece que sí porque va justo con tu preocupación.

Entrevistadora: se sabe que el lenguaje vehicula ideas diferentes, que no se pueden construir pensamientos iguales desde la escritura y desde la oralidad, es inútil. En Veladuras vi exactamente uno de los problemas que me parece importante y es como las mujeres no pueden decir todo lo que piensan porque el hilo del discurso no encaja, entonces Rosa es el típico personaje femenino que no puede vehicular información en su discurso, no lo puede desatar sino por pildoritas muy chicas. Ese proceder 
se ajusta al discurso contenido de esta chica, casi enmudecida. Además, está el hecho de que ella buscaba su identidad como en el espejo invertido no? No a través de la madre sino del padre. Pero usted como autora por qué cree que Veladuras está catalogada como novela juvenil si desarrolla esos temas tan adultos?.

Entrevistada: Porque yo tenía ya una historia importante en los libros juveniles y entonces, es un libro que está ahí en el borde, como también está Stefano, entonces yo tengo mucho de una escritura, que ayuda tanto para un lado como para el otro.

Entrevistadora: Volviendo al problema de lo femenino y lo masculino, pienso en cómo aparecen los derechos de personas que no se ajustan a la heterosexualidad reglamentada, ni al sistema de oposiciones que como occidentales necesitamos construir para ver el mundo, como lo femenino y lo masculino, como el Yin y el Yang, siempre necesitamos un par. Usted cree que si uno analiza la literatura escrita por mujeres y encuentra algo que sea propio del decir femenino contribuirá de alguna manera a clarificar el problema, porque yo pienso que el momento es confuso.

Entrevistada: $\mathrm{Si}$, en Argentina, no sé cómo estará acá, la cuestión en Argentina sí ha avanzado mucho en estos años sobre los derechos sexuales, de la cuestión de género, y entonces bueno, está el universo trans, que además ya no es suficiente porque hay una variedad digamos entre varones heterosexuales y mujeres heterosexuales en el medio hay una complejidad hay una diversidad, yo creo que se ha avanzado mucho en la cuestión de la libertad de autopercepción y la cuestión es, quizá como se auto percibe cada persona. En cuanto a la escritura, si hay algo específicamente femenino en mi escritura, por una parte yo creo que todo lo que uno es, se pone en alto cuando uno escribe. Entonces sí, está me parece que la cuestión de ser mujer es un punto importante o al menos en el acto de la escritura de las mujeres pero no como una cuestión única porque la identidad tiene muchas capas, yo podría decir que escribo como mujer que soy, quien soy 
yo? Muchas cosas, soy mujer, soy hija de un inmigrante, tengo una procedencia de clase media baja, una procedencia económica de clase media baja, tengo una procedencia cultural un poquito más alta que la económica, soy de una generación que en mi país salió a luchar por las condiciones del país, digamos soy de la generación del 70 que eso también tiene un marca, soy una persona que pasó por la universidad, soy, qué sé yo, una sexagenaria, soy madre, me crie en la llanura; bueno hay una cantidad de cosas que hacen como capas, todo eso aparece de algún modo en la escritura, no sé de qué modo, no es un modo deliberado pero yo sé que el sentir, algo del sentir mujer, bueno soy una persona que ha tomado conciencia del género muy temprano y de las luchas por ejemplo yo me he pronunciado y digamos en mi país en este momento hay una lucha muy fuerte por el aborto legal porque mueren muchas mujeres. No sé cómo sea en Colombia porque hay muchas, o sea el aborto se hacen 500.000 a 700.000 abortos por año en la argentina, pero bueno solo se lo pueden hacer las mujeres que pueden pagar en una clínica, en las clandestinas mueren cantidades. Yo he tomado posición con respecto al aborto, público, libre, gratuito y seguro, en los años 80 cuando muy poca gente tomaba esa posición, bueno en el año 2012 se formó parte de un almanaque esto se volvió más violento y más fuerte ahora desde el 2014 en adelante, pero yo formé parte de un almanaque donde 12 mujeres nos pronunciábamos con una filmación, quiero decir, eso ha formado parte de mí, todo eso se pone en alto pero no se pone en alto de un modo, me parece a mí, deliberado. A ver yo soy un militante de tal cosa o yo tomo conciencia de género entonces no, aparece una imagen yo la sigo y voy tras eso y lo que soy entra ahí como quiera, porque uno es mucho más de lo que uno cree pensar de uno entonces se complejiza y la escritura trabaja con toda esa complejidad, la mente deja eso, quizás ese es un modo muy femenino de actuar, un modo de escribir no a partir de las ideas sino como de sensaciones, emociones, deseo no? entonces, eso sí lo encuentro muy femenino, pero, no hay una cosa inequívoca entonces creo que si en mi condición de mujer, una mujer biológicamente hablando o en una auto percibida 
mujer, una mujer trans por ejemplo, yo conozco escritoras trans, bueno la condición mujer sí marca como otra, una marca muy fuerte que se suma a otras marcas que uno también tiene, no?; pero no creo que haya un único modo de escribir como mujer, digamos, esto que hagamos esa cosa binaria, la escritura femenina es así y la escritura masculina es así, o sea, no creo que sea de ese modo, yo con otras dos mujeres, una de ellas es una hija mía que también es poeta Juana Luján y la otra es una profesora, una chica también muy joven Carolina Rosi, las 3 dirigimos una colección de narradoras argentinas, de rescate de escritoras argentinas que ya no están, porque algunas de ellas excelentes, sus obras han sido invisibilizadas o muy olvidadas entonces nosotros las editamos en una colección que sale en una editorial universitaria y las buscamos, buscamos sus obras que han quedado sin editar o que están guardadas hace mucho tiempo, las ponemos otra vez en circulación. Son muy distintas. Hay escritoras con una obra impregnada de lo social, hay otras que son de literatura fantástica, o de humor o policiales o este... son muy distintas. Nos interesa la escritura de las mujeres, no un cierto tipo de escritura, porque sabes lo que sucede? A veces se intenta encasillar lo que escribimos las mujeres. Es escritura de mujeres la que habla de las pasiones o de los niños o sea lo infantil o las novelas románticas, todo lo otro, lo experimental, lo político, lo erótico se saca un poco de ahí no?. Y ese encasillamiento hace que las escritoras no entren en el canon de la gran literatura. Por ejemplo, estas que nosotras rescatamos son escritoras extraordinarias, han sacado premios, han sido traducidas, ya no están vivas pero sus compañeros varones no las dejaron entrar en el canon, entonces, salvo dos o tres por condiciones personales y también por condiciones sociales porque una de ellas es Silvina Ocampo, que era de la altísima aristocracia de la argentina, amiga de Borges, ella y su hermana Victoria eran mujeres muy poderosas, digamos unas escritoras no tan excepcionales pero de un sector con poder, entonces, ella terminó siendo canonizada pero otras no, o sea han sido vistas como escritoras para mujeres. Mujeres que escriben para otras mujeres, para entretenerlas, han sido criticadas muchas 
de ellas, burladas también. Cuando hay muchas que son escritoras extraordinarias que recién ahora se están recuperando en el verdadero lugar que debieron ocupar.

Entrevistadora: me inquieta lo que usted dice porque está en el corazón de mis preguntas. Yo pienso que hay una crítica fuerte al centralismo patriarcal, al centralismo de la razón; las mujeres no participaron en la construcción de ese modelo de ser humano; hoy en día que las mujeres tienen más voz, pueden escribir así sea contra la corriente de la invisibilización. Las mujeres han sido la contraparte, nunca olvidaron que el proyecto del mundo y el conocimiento de mundo estuviese bajo la égida de lo racional mientras que ellas no, porque también se les impidió el acceso a la universidad por mucho tiempo y bueno, ellas elaboraron un lenguaje que está muy basado en el afecto que ni siquiera respeta la sintaxis de la proposición lógica y cosas así. Si uno analiza estos lenguajes que de algún modo como usted dice quedan en la escritura, de pronto buscando allí, no podremos encontrar como las mujeres tienen una propuesta para mejorar ese modelo dual, no para reemplazarlo porque no creo que sea una lucha de opuestos así aniquilantes sino que se trataría de compensar las fallas de este modelo.

Entrevistada: yo creo que irá apareciendo en todas estas filtraciones que las mujeres estamos haciendo en distintos ámbitos, pero, claro si la literatura es una experiencia en el lenguaje, uno se está buscando en el lenguaje cuando está escribiendo.. Habla de lo no organizado, por ejemplo, Lengua madre es una novela que funciona fragmentariamente, porque es alguien que está mirando unas cartas y a partir de ahí construye hacia atrás la historia. En ese sentido se vincula con Veladuras que construye hacia atrás también porque el tema de la identidad siempre me ha resultado, la búsqueda que tampoco es de algo quieto. La identidad está en permanente movimiento. Digamos yo tengo mucho interés por la escritura de las mujeres, leo mucha escritura de las mujeres de mi país y de otros países, es muy importante para mí rescatar las 
mujeres de la historia de la literatura en mi país. Hoy que hay más permiso para muchas cosas, a veces las escritoras jóvenes ignoran todo ese esfuerzo hecho por las generaciones anteriores. De pronto publicamos una novela de una escritora argentina de los años 30 que era periodista y cubrió en el campo de batalla la lucha entre republicanos y franquistas en España y ella escribió una novela y muchas letras de tango, todas, con seudónimos de varones; todo el mundo las canta y las adoptan como si un hombre fuera el autor. Son tangos y ella es una mujer de clase media. Eso me interesa.

Entrevistadora: hay mucho para indagar en este universo. De todas maneras yo no tengo una respuesta, estoy leyendo mujeres, encuentro cosas que persisten, como por ejemplo esto de la búsqueda de la identidad en el espejo de las anteriores generaciones y eso es algo que se me atraviesa tanto en la novela, porque es una chica mirándose en su madre, en su abuela, acordando, diferenciando en esa lucha tanto como una colección buscar las escritoras que estoy editando, aquí en Colombia hay una que también lo hizo con madre, abuela e hija las tres con su mismo nombre Julianas, que se llama Alba Lucía Ángel y se llama Misia Señora la novela y es ese mismo problema como una nieta se busca en su abuela y en su madre pero aquí inmersa en una trampa patriarcal donde todo el tiempo le están señalando como histérica o loca. Creo que es un tema muy recurrente. Pero hay otras cosas, por ejemplo encontré una escritora colombiana que se llama Laura Restrepo que escribió sobre ángeles, en el mismo año, en el 95, que un hombre, colombiano también, escribió sobre ángeles. La novela de él es muy intelectual, una búsqueda clásica que exhibe mucha racionalidad en sus asuntos literarios. Ella, en cambio, escribe una novela sobre ángeles porque aparece un ángel en una comunidad y cuando la protagonista va a hacer una crónica sobre el ángel, termina embarazada del ángel. Interpreto la situación de los dos autores, como un modo de decir que cuando yo miro el mundo como hombre, lo miro desde la lejanía de la objetividad. En cambio cuando la mujer lo mira, puede darle más sentido a lo que ve si lo hace de manera vivencial. Y lo 
imperfecto, la búsqueda de lo que está a medio hacer, de lo que no se puede resolver, de lo que queda, el desvío de lo esperado, el desvío de los mandatos, el desvió de lo predeterminado, define muy bien el caso de una escritora colombiana que es la madre Laura canonizada hace unos años, una monja muy prolífica en sus asuntos misionales pero también en sus asuntos literarios porque mantuvo una revista durante seiscientos números, con un ejemplar semanal. Escribió una autobiografía de unas mil páginas y escribió relatos de misión, diarios, y cartas para los obispos y padres de la iglesia. Esa literatura muestra cómo realizó su proyecto misional en contravía de la institución eclesiástica. Los sacerdotes querían que ellas, Laura y sus monjas, atrapara a los indios y les tendieran una red para catequizarlos. Pero Laura creía que al hacerlo, los inhabilitaban como indígenas. Como ella estaba enamorada de la raza indígena, entonces se iba a los bohíos de ellos si quería darles alguna lección. Era una mujer súper voluminosa y caminaba detrás de los indios, que aparte de todo eran trashumantes. Tan bella me pareció su lucha que terminé por hacer una novela. Está sin publicar, pero me interesa su lenguaje, el discurso que usa para escribir todo eso porque su lenguaje también es un desvió de los mandatos académicos: Habla con refranes, involucra los refranes como una manera de justificar lo que ella hace, pues sus métodos no tienen justificación dentro de la racionalidad patriarcal. De hecho esta figura es una pariente lejana de mi mamá y cuando yo era niña en casa de mis abuelos se hablaba de ella. Pero cuando se hablaba de ella alguien ordenaba callar porque Laura era la oveja negra, era la mala y de ella no había un retrato ni había nada. Sólo había retratos de los curas de la familia. Las mujeres usan estrategias no muy santas para burlar el orden patriarcal y eso es lo que yo quiero encontrar además de encontrar otra cosa que está en la novela y es el asunto de cómo es la imagen de una mujer que construye o es construida por otra mujer. Y eso compararlo con la imagen de una mujer construida con moldes patriarcales; ¿Cómo lo percibe usted? 
Entrevistada: Yo creo que la imagen de mujer, bueno hay que ver qué escritor ¿no?, uno no puede generalizar pero en general hay una mayor complejidad en las imágenes de mujeres construidas por mujeres que en las construidas por varones, aunque con muchas excepciones, porque no se puede generalizar. Pero muchas veces, la mujer desde la mirada del varón está estigmatizada y por lo común sufre otra estigmatización que es peor para mí: la idealización que pone a los personajes femeninos en ese lugar en el que no se manchan y en el que hay que cuidarlas; algo virginal o algo bueno. En esta tensión entre la prostituta y la virgen o entre la madre y la puta, ese lugar de extremos (otra vez lo binario). Me parece que en general, en la buena escritura hecha por mujeres, la mujer que aparece es una mujer más compleja que tiene de todo eso, no?

Entrevistadora: Sí. Pensaría yo qué es eso, el arquetipo domina la construcción masculina del personaje femenino, las mujeres si rompen el arquetipo,

Entrevistada: Por ejemplo todas estas discusiones de hoy, que yo también lo veo en las mujeres jóvenes, en la generación de mi hija todas las discusiones en torno a la maternidad todo lo que se ha construido sobre eso, hay que ser padre y la madre es, siempre que se yo, maravilloso que nunca se cansa que todo lo hace pero más allá de que haya un gozo en el tema de la maternidad en muchas mujeres, que tampoco se ve en todas, eso también implica toda una lucha interna o sea no es algo dado por naturaleza, ni algo tan exento de tensión, hay algo en las mujeres con lo carnal, visceral, las pasiones la intensidad con la que una mujer puede deshacer todo y tirar todo por la borda para seguir algo propio o para defender a su cría o para defenderse a sí misma en sus deseos eso es algo que no siempre los varones pueden percibir.

Entrevistadora: De todas maneras, es una riqueza poder sentirse escritora mujer y como con un impulso para escribir que proviene de ese hecho. 
Entrevistada: Sí, creo que eso produce riqueza en la literatura de todas maneras, tanto en las mujeres como en la literatura en general, me parece que mucho tiene que ver con esta lucha externa de afuera, de lo que sucede en el afuera en el contexto social en el que estamos, por ejemplo hace poco se hizo una marcha en diferentes ciudades de Argentina y son cientos de miles de mujeres que han salido a las calles por el de Ni una menos, que es un movimiento por el tema de los asesinatos, unido a la lucha por el aborto porque está la ley en discusión en el congreso en este momento. Entonces la marcha que es sobre la avenida de mayo, se ve toda verde porque las mujeres han levantado todos sus pañuelos verdes y alguien sacó una foto y se ve una marea verde, bueno, antes por ejemplo en los años 80 , trabajaba un grupo de mujeres y bueno nos costaba decir, lo decíamos al interior pero hacia afuera no a cualquiera le podías decir que eras feminista, ahora veo a las chicas de 18 años llevando un cartel yo soy feminista, o sea yo lucho por mis derechos. Pueden habitar más esa palabra y esa lucha y ese reclamo y es porque otras generaciones anteriores lo hicieron, Nada se hace solo.

Entrevistadora: Pero tampoco se puede banalizar, porque a veces los derechos se van convirtiendo como en nada, se van diluyendo.

Entrevistada: Hay que trabajar con la conciencia por eso, porque si no esos derechos se pierden, se pueden perder muy fácilmente o se cree que vienen como del cielo y no de la lucha de otras mujeres a eso me refiero.

Entrevistadora: María Teresa, sus proyectos futuros para escribir textos.

Entrevistada: En este momento estoy cerrando un libro álbum, yo escribí los textos para la ilustradora, todavía no tenemos el título. Y la obra de teatro en la que estoy trabajando, además, estoy puliendo unas crónicas que relacionan lo íntimo con lo 
social y pequeñas historias. Estoy con un cuento largo que no se si llegará a ser una novela, también está el tema de la mujer otra vez, tal vez se vaya a llamar el vestido. Se trata de una mujer casada con un delegado de una fábrica, o sea un hombre con conciencia, pero, que tiene una actitud con ella muy machista. Ella está de madrina de boda de un sobrino y tiene un vestido largo de fiesta hecho para eso y él le dice que se quiere ir y ella como no maneja, se tiene que buscar otro vestido. Por ahí va. Solo sé que el centro es una mujer.

Entrevistadora: ¿Como escritora argentina qué nombre de escritoras colombianas llegan a usted?

Entrevistada: he leído mucho la obra de Yolanda Reyes, porque somos amigas nos intercambiamos, he leído a Piedad Bonet, he leído a Laura Restrepo, a Carolina Sanín algunas cosas de ella, muy aguda, he leído varias cosas de ella, Pilar Quintana me resultó muy interesante, La perra y Colección de polvos, son dos novelas y unos cuentos sueltos que también leí, pero esas dos novelas me resultaron interesantes, La perra particularmente.

Entrevistadora: ¿Y en Latinoamérica qué nombres de mujeres son infaltables, que tendríamos que tener en cuenta?

Entrevistada: De Lina Meruane creo que he leído casi todo o por lo menos las obras principales que me gustan mucho, también una chilena menos conocida que se llama Andrea Stefanowicz, que me resultó muy interesante, también una novela con muchos cuentos, Pía Barros de Chile, Diamela Eltit por ejemplo son escritoras interesantes, de las bolivianas Gio Rivero y Liliana Colanzi. Hay escritoras que son excelentes, sobre todo como las cuentistas, Luisa Valenzuela, Liliana Heker, y otras muy fuertes y que están en actividad, luego hay una camada muy grande de escritoras de mi generación y escritoras más jóvenes, o sea Cabezón Cámara, Lilia Lardone, por ejemplo, y muchas más. 
Entrevistadora: usted que ha trabajado en antologías, ¿cuáles son los criterios que usa para valorar una escritura femenina?.

Entrevistada: Sí, hay varias condiciones. Una es la condición es que si son mujeres o no, la otra es que si son de la capital o son de las provincias por ejemplo eso no sé cómo funcione acá, allá hay una cosa, se cruzan varias cuestiones de pronto se hace una antología y la mayoría son escritoras de Buenos Aires, que están ahí como a la mano o que las editaron unas editoriales más grandes que las escritoras de provincias que escriben excelente entonces eso también es un tema, yo como he vivido siempre en provincia, yo tengo una repercusión nacional y generalmente estoy incluida en esas cosas, siempre estoy hablando por otras compañeras que no son tomadas o que no están en el centro. Qué criterios?, Yo tomaría si hiciera una antología, yo creo que una antología a veces se hace con hostilidad yo creo que para hacer una antología, hay que leer mucho primero no solo lo que está en el centro sino lo que está escondido, porque si no uno lo que hace es repetir lo que otros ya han hecho entonces yo que haría, leería mucho no solo lo centrado sino lo descentrado y haría algo que tuviera diversidad, diversidad de generaciones, edades de las mujeres, diversidad de exploración del lenguaje, diversidad de género. Lo más cuestionable me parece es la tendencia a la uniformización ahí perdemos las escritoras mujeres y ahí pierde sobre todo la literatura y el lector porque se tiende a uniformar qué es lo que intenta el mundo contemporáneo, uniformar las voces, uniformar asuntos uniformar las situaciones y es en esos desvíos donde está lo verdadero.

Entrevistadora: Muy bien, me encantó haber conversado con usted, qué dicha estar aquí, me llevo muchas cosas, muchas inquietudes, muchos nombres para explorar y me pareció excelente en esta tarde escucharla, muchas gracias

Entrevistada: Muchas Gracias. 
Este libro terminó de imprimirse en Abril del 2021, en los talleres gráficos de Gráficas Olimpica, bajo el cuidado de sus autores. Pereira, Risaralda, Colombia. 
Consuelo Chica (Salamina, Caldas, Colombia, 1966).

Magíster en Lingüística, Licenciada en español y literatura de la Universidad Tecnológica de Pereira y Tecnóloga en Sistemas de la Universidad Antonio Nariño, sede Pereira. Es docente catedrática del Departamento de Humanidades de la Universidad Tecnológica de Pereira, en el área de Comunicación y pensamiento crítico. Sus intereses académicos se centran en la didáctica de los procesos de lectura $y$ escritura en el ámbito universitario.

Autora de capítulo de libro "Creación de neologismos en la lengua signada colombiana en procura de una política de Estado" (2018).

Pertenece al Grupo de Investigación Arte y Cultura de la Universidad Tecnológica de Pereira

\section{conchita@utp.edu.co}

\section{Olga Lucía Carmona Marín,}

(Riosucio-Caldas, Colombia,1970).

Magister en Comunicación y Licenciada en Español y Comunicación de la Universidad Tecnológica de Pereira. Abogada y Especialista en Derecho Constitucional de la Universidad Libre de Pereira. Docente Titular del Departamento de Humanidades de la Universidad Tecnológica de Pereira.

Autora de los libros: Práctica pedagógica y compromiso social. Los proyectos formativos para una educación en derechos humanos y democracia. (2009); Coautora de : Educación para la Paz: Ensayos para ensayar una propuesta pedagógica, (2018) y Formación de sujetos políticos desde una experiencia de educación para la paz (2019).

Ha publicado artículos en revistas nacionales e internacionales.

Pertenece al grupo de investigación en Estudios Políticos y Jurídicos de la Universidad Tecnológica de Pereira. 
El presente texto indaga en un corpus narrativo de autoras latinoamericanas contemporáneas con la intención de vincular sus temáticas, lenguajes y técnicas literarias con los modos de vida, expectativas y roles que han correspondido históricamente a las mujeres en la cultura occidental. El proyecto de investigación que le da origen explora la relación entre ética y literatura $y$, aunque no se inscribe en ninguna de las corrientes feministas, comparte con el feminismo de la diferencia la necesidad de resignificar la experiencia femenina de mundo, así como pensar una humanidad por fuera del proyecto androcéntrico. En este sentido, las autoras toman posición, no para contribuir al debate político, sino para postular esa experiencia y esos relatos como alternativa a las mediaciones y significaciones usuales de nuestros universos simbólicos. Una de las derivas de la corriente de la diferencia apunta a la tarea filosófica de ligar teoría y práctica en un orden marcado por la experiencia femenina, del cual resultaría la crítica a la cultura patriarcal, el reconocimiento de la diversidad y la incorporación de las potencias creadoras de la vida y de la lengua materna. Para este corpus se usó la categoría epicidad como conjunto de operaciones narrativas: linealidad del tiempo, lenguaje proposicional con organización jerarquizada de las experiencias, finales cerrados, trama agonística y alusión a un proyecto de vida que puede abrir 0 clausurar límites para la humanidad. La crítica literaria encuentra que las novelas femeninas, con frecuencia, carecen de estas propiedades y en cambio incluyen la experiencia de estar presentes para otros, con lo que aparece un universo de categorías narrativas que las investigadoras han denominado antiepicidad. 